ORNL/TM-2019/1413

ORNL/NTRC-085, Rev. 0

\title{
Test Report for the Qualification Testing of the ORNL-SFC-W-1 Special Form Capsule
}

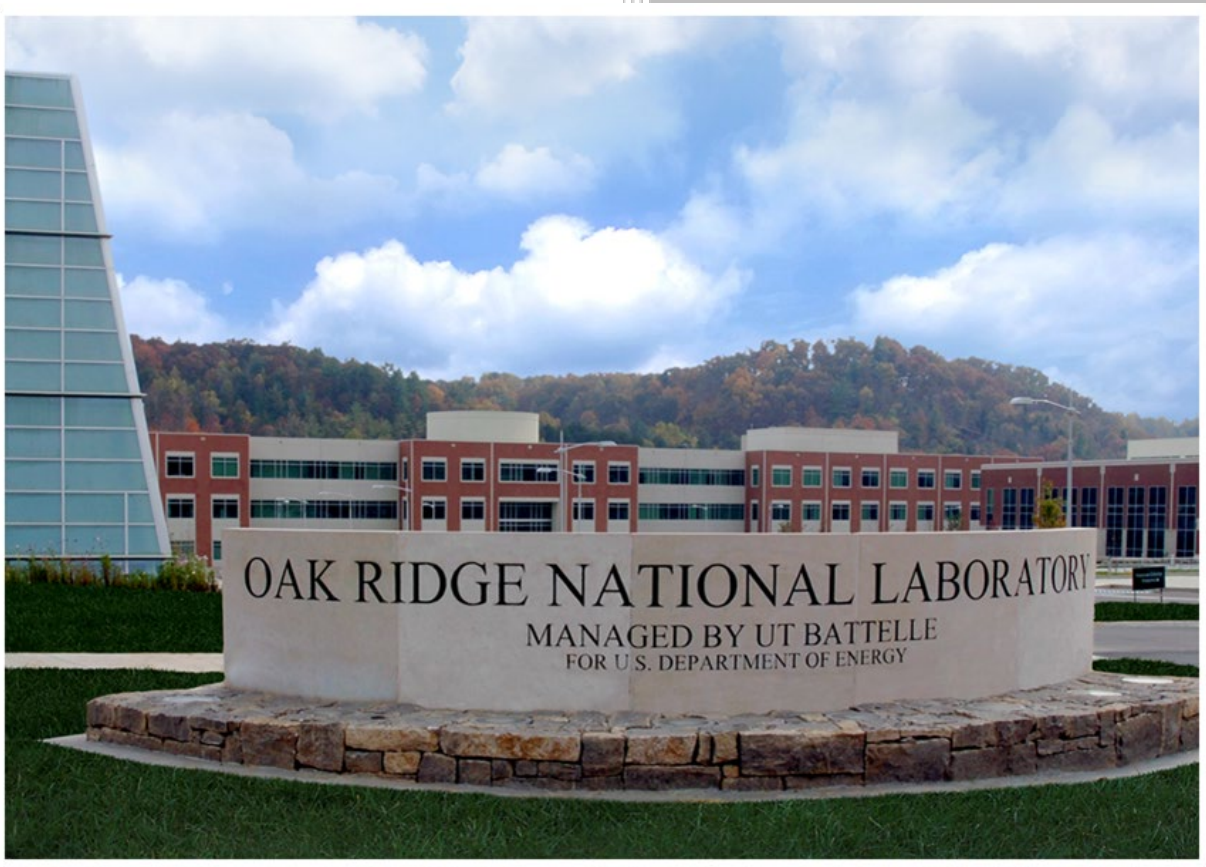

Approved for public release.

Distribution is unlimited.
A. I. Adeniyi
O. A. Martinez, $\mathrm{PhD}$

February 2020 


\section{DOCUMENT AVAILABILITY}

Reports produced after January 1, 1996, are generally available free via US Department of Energy (DOE) SciTech Connect.

Website http://www.osti.gov

Reports produced before January 1, 1996, may be purchased by members of the public from the following source:

National Technical Information Service

5285 Port Royal Road

Springfield, VA 22161

Telephone 703-605-6000 (1-800-553-6847)

TDD 703-487-4639

Fax 703-605-6900

E-mail info@ntis.gov

Website http://classic.ntis.gov/

Reports are available to DOE employees, DOE contractors, Energy Technology Data Exchange representatives, and International Nuclear Information System representatives from the following source:

Office of Scientific and Technical Information

PO Box 62

Oak Ridge, TN 37831

Telephone 865-576-8401

Fax 865-576-5728

E-mail reports@osti.gov

Website http://www.osti.gov/contact.html

This report was prepared as an account of work sponsored by an agency of the United States Government. Neither the United States Government nor any agency thereof, nor any of their employees, makes any warranty, express or implied, or assumes any legal liability or responsibility for the accuracy, completeness, or usefulness of any information, apparatus, product, or process disclosed, or represents that its use would not infringe privately owned rights. Reference herein to any specific commercial product, process, or service by trade name, trademark, manufacturer, or otherwise, does not necessarily constitute or imply its endorsement, recommendation, or favoring by the United States Government or any agency thereof. The views and opinions of authors expressed herein do not necessarily state or reflect those of the United States Government or any agency thereof. 
ORNL/2019/1413

ORNL/NTRC-085

Rev. 0

Reactor and Nuclear Systems Division

\title{
TEST REPORT FOR THE QUALIFICATION TESTING OF THE ORNL-SFC-W-1 SPECIAL FORM CAPSULE
}

\author{
A. I. Adeniyi \\ O. A. Martinez, PhD \\ February 2020 \\ Prepared by \\ OAK RIDGE NATIONAL LABORATORY \\ Oak Ridge, TN 37831-6285 \\ managed by \\ UT-BATTELLE, LLC \\ for the \\ OAK RIDGE NATIONAL LABORATORY \\ Nuclear Security and Isotope Technology Division \\ US DEPARTMENT OF ENERGY \\ under contract DE-AC05-00OR22725 Mod 877
}





\section{REVISION LOG}

\begin{tabular}{|c|l|l|l|}
\hline Revision \# & \multicolumn{1}{|c|}{ Issue Date } & Pages affected & \multicolumn{1}{c|}{ Comments } \\
\hline Revision 0 & February 2020 & All & $\begin{array}{l}\text { Original Issue. } \\
\text { Please note that the capsule named } \\
\text { "Mark 42 Pu" in the test records was } \\
\text { renamed "ORNL-SFC-W-1" at the } \\
\text { time of report writing. }\end{array}$ \\
\hline & & & \\
\hline & & & \\
\hline & & & \\
\hline
\end{tabular}





\title{
TEST REPORT FOR THE SPECIAL FORM QUALIFICATION TESTING OF THE ORNL-SFC-W-1 SPECIAL FORM CAPSULE
}

\author{
Prepared for \\ Oak Ridge National Laboratory \\ Nuclear Security and Isotope Technology Division \\ Prepared by \\ A. I. Adeniyi \\ O. A. Martinez, $\mathrm{PhD}$ \\ Oak Ridge National Laboratory \\ Reactor and Nuclear Systems Division \\ Used Fuel Systems Group \\ at the \\ National Transportation Research Center
}

\section{APPROVALS}

\section{Name \\ Position \\ Date \\ Abiodun Adeniyi \\ Digitally signed by Abiodun Adeniyi Date: 2020.11 .18 14:44:34 -05'00'}

A. I. Adeniyi
Digitally signed by Oscar A. Martinez, Ph.D.
Date 2020.11 .18 15:40:59-05'00'

\section{O A. Martinez, PhD ORNL Package Testing Program}

\section{Michael B. Houston Digitally signed by Michael B. Houston \\ Date: 2020.11.23 11:12:11 -05'00'}

Michael Houston $\quad$ ORNL Package Testing Quality Representative
Rose Montgomery Digitally signed by Rose Montgomery
Date: 2020.11 .23 11:32:49-05'00'

Rose Montgomery Used Fuel Systems Group Leader 



\section{CONTENTS}

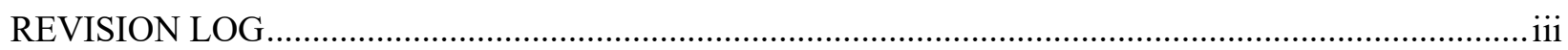

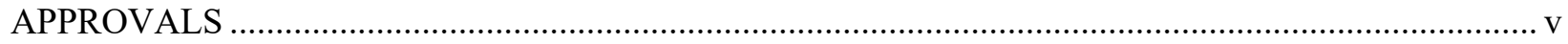

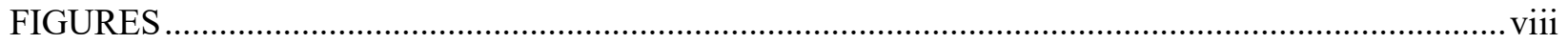

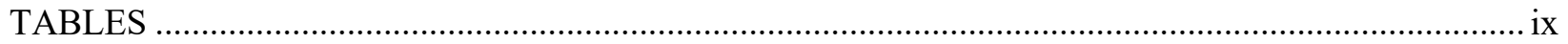

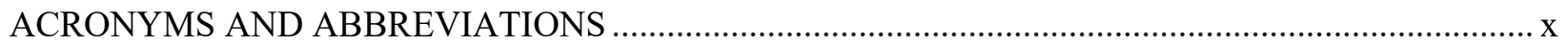

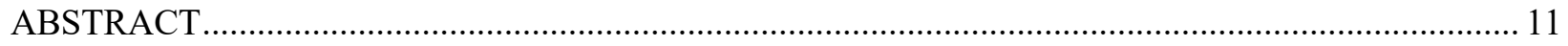

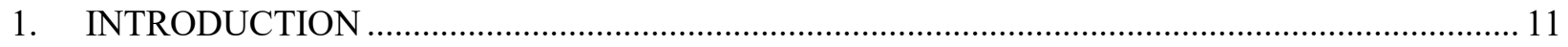

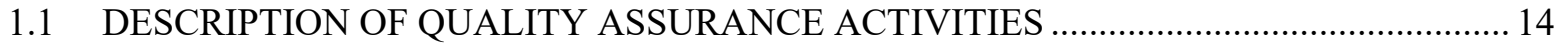

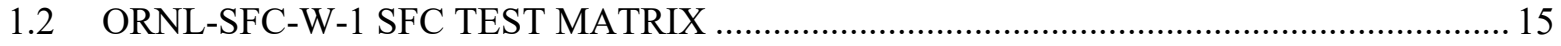

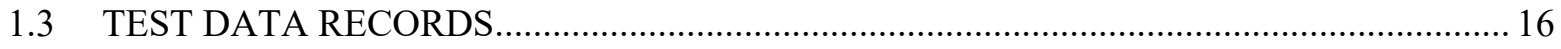

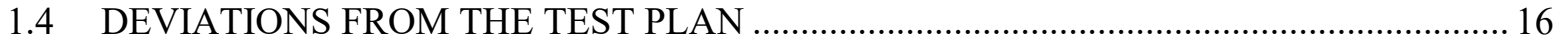

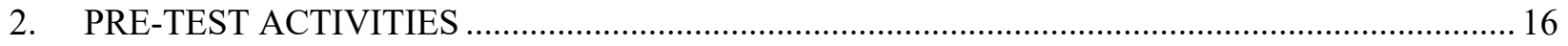

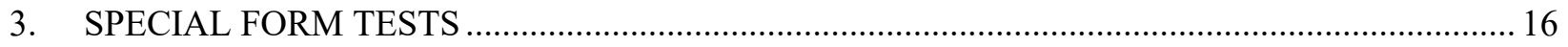

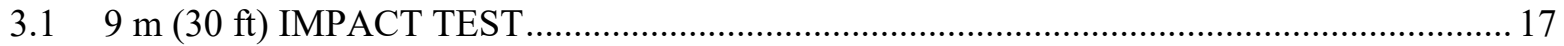

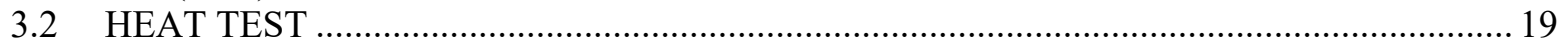

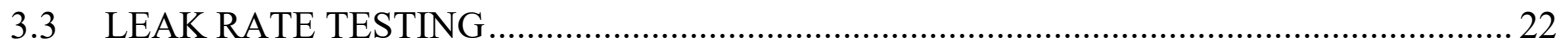

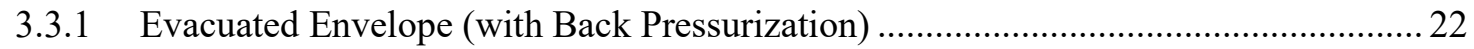

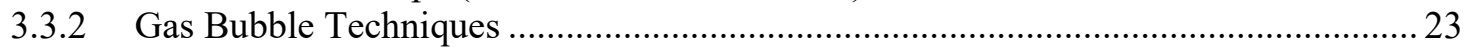

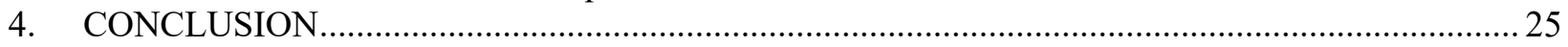

APPENDIX A. ORNL-SFC-W-1 SPECIAL FORM CAPSULE DRAWINGS ....................................... A-1

APPENDIX B. TEST FORMS FOR ORNL-SFC-W-1 SPECIAL FORM CAPSULE …..................... B-1

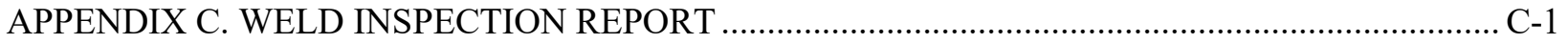

APPENDIX D. LEAK TEST NDT EXAMINER TECHNICIAN CERTIFICATION …...................... D-1

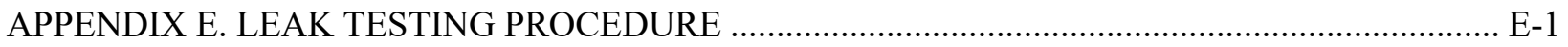

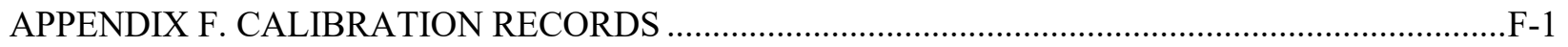




\section{FIGURES}

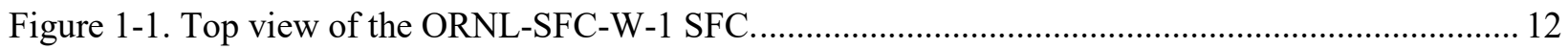

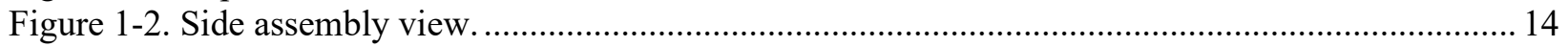

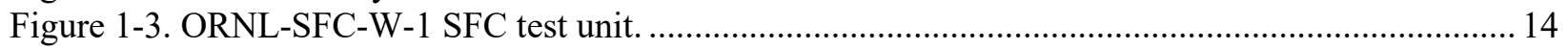

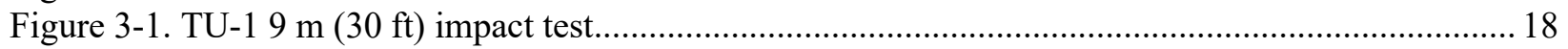

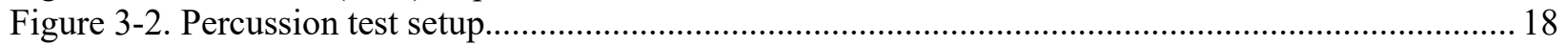

Figure 3-3. Before and after percussion test of TU-1 (note billet impact point above letter "T")............. 19

Figure 3-4. The RAD-O-GLOW furnace used for ORNL-SFC-W-1 capsules thermal test..................... 19

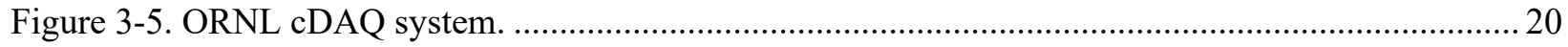

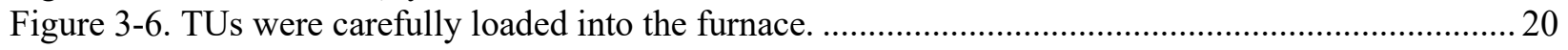

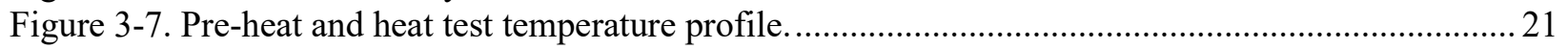

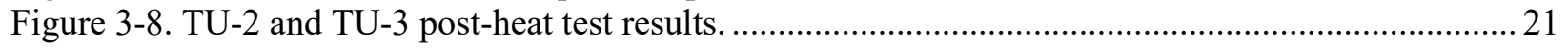

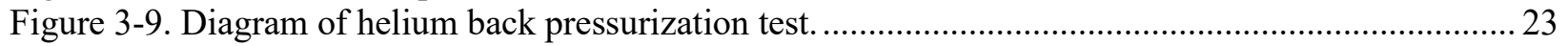

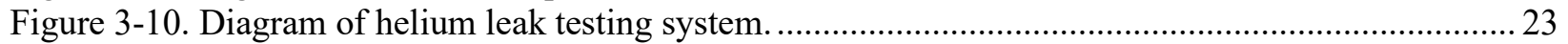

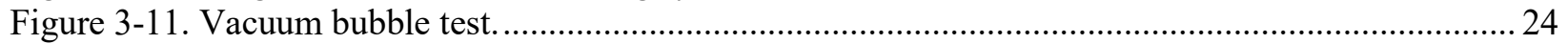

Figure A.4-1. ORNL-SFC-W-1 special form capsule engineering drawing ........................................ A-3 


\section{TABLES}

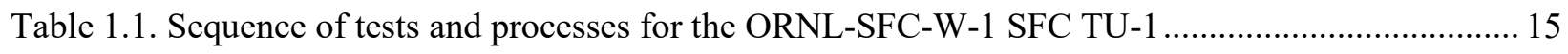

Table 1.2. Sequence of tests and processes for the ORNL-SFC-W-1 SFC TU-2 and TU-3 .................... 15

Table 3.1. Leak rate test variables and results for TU-1, TU-2 and TU-3 ............................................ 24

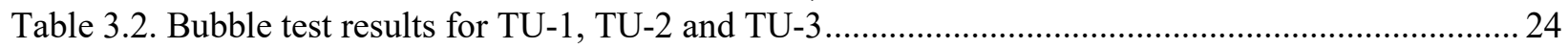




\section{ACRONYMS AND ABBREVIATIONS}

$\begin{array}{ll}\text { ANSI } & \text { American National Standards Institute } \\ \text { ASNT } & \text { American Society for Nondestructive Testing } \\ \text { ASTM } & \text { American Society for Testing and Materials } \\ \text { cDAQ } & \text { Compact Data Acquisition } \\ \text { CFR } & \text { US Code of Federal Regulations } \\ \text { IAEA } & \text { International Atomic Energy Agency } \\ \text { IBR } & \text { incorporated by reference } \\ \text { ISO } & \text { International Standards Organization } \\ \text { NDT } & \text { nondestructive testing } \\ \text { NSC } & \text { Y-12 National Security Complex } \\ \text { ORNL } & \text { Oak Ridge National Laboratory } \\ \text { PTP } & \text { Package Testing Program } \\ \text { QA } & \text { quality assurance } \\ \text { QAPD } & \text { quality assurance program description } \\ \text { REDC } & \text { Radiochemical Engineering Development Center } \\ \text { RHACS } & \text { Research Hazard Assessment and Control System } \\ \text { RSS } & \text { research safety summary } \\ \text { SBMS } & \text { Standards Based Management System } \\ \text { SFC } & \text { special form capsule } \\ \text { TC } & \text { thermocouple } \\ \text { TIG } & \text { tungsten inert gas } \\ \text { TU } & \text { test unit }\end{array}$




\begin{abstract}
Three prototypes the ORNL-SFC-W-1 special form capsules (SFCs) of the same design were evaluated to determine if the requirements of Title 49, Code of Federal Regulations (CFR), Part 173.469, Tests for Special Form Class 7 (Radioactive) Materials, were met. The results of the special form tests are documented in this test report.
\end{abstract}

This report describes the special form testing activities performed on the three ORNL-SFC-W-1 capsules. The test units were designated as TU-1, TU-2 and TU-3. TU-1 was subjected to leak testing, impact testing and percussion testing. TU-1 was leak tested using the leak rate test specified in 49 CFR 173.469(a)(4)(i). The impact test was conducted according to the requirements in 49 CFR 173.469 (b)(1). The percussion test that was carried out on TU-1 was conducted in accordance with 49 CFR 173.469 (b)(2). Both TU-2 and TU-3 were subjected to a leak rate test as specified in 173.469(a)(4)(i) and a heat test as specified in 49 CFR 173.469(b)(4). Each test unit was leak tested before and after these respective tests.

The leak rate tests performed were helium back-pressure tests and bubble tests as specified in American National Standards Institute (ANSI) N14.5-2014. The measured leak rates were converted to standard condition leak rates as specified in American Society for Testing and Measurement (ASTM) E 493. The determined standardized leak rates obtained from the test and the calculations for all the test units met the requirements for special form certification.

The testing was performed under the direction of the Oak Ridge National Laboratory (ORNL) Package Testing Program (PTP).

\title{
1. INTRODUCTION
}

This test report describes the special form testing activities for the ORNL-SFC-W-1 special form capsules (SFCs) tested to demonstrate compliance with the requirements of Title 49, Code of Federal Regulations (CFR), Part 173.469, Tests for Special Form Class 7 (radioactive) materials.

All testing was performed under the Oak Ridge National Laboratory (ORNL) Package Testing Program (PTP) quality assurance plan outlined in NTRC-PRF-QAP-001, Rev. 3, "Quality Assurance Plan for the Package Testing Program.”

The empty weight of the sealed capsule is $0.42 \mathrm{~kg}$. $(0.92 \mathrm{lb})$, and the volume of the metal of the empty capsule is $51.6 \mathrm{~cm}^{3}\left(3.15 \mathrm{in}^{3}\right)$. The interior volume of the empty capsule is $102.0 \mathrm{~cm}^{3}\left(6.20 \mathrm{in}^{3}\right)$.

Figure 1-1 illustrates the ORNL-SFC-W-1 SFC. The test specimens, which are designated as TU-1, TU2 and TU-3, were fabricated for testing purposes. One specimen (TU-1) had a stainless steel round bar 1 -inch in diameter and 2 inches long as a surrogate inner container (content) for percussive testing. This bar is a conservative representation of the mass for the inner containers of all three specimens. The bar weighs $0.21 \mathrm{~kg}(0.46 \mathrm{lb})$. The total weight of TU-1, with surrogate inner container included, is $1.38 \mathrm{lb}$ $(0.63 \mathrm{~kg})$. The volume of the TU-1 surrogate is $25.7 \mathrm{~cm}^{3}\left(1.57 \mathrm{in}^{3}\right)$. The internal void volume of TU-1, with surrogate, is $75.9 \mathrm{~cm}^{3}\left(4.63 \mathrm{in}^{3}\right)$. The other two specimens will each encapsulate an inner container having nonradioactive surrogate solid material within, which will be used to simulate Class 7 radioactive material. TU-2 has a nonradioactive surrogate $\left(\mathrm{ZrO}\left(\mathrm{NO}_{3}\right)_{2}\right)$ for thorium oxide inside a stainless-steel inner container. TU-3 has a nonradioactive surrogate $\left(\mathrm{La}\left(\mathrm{NO}_{3}\right)_{3}\right)$ for actinium nitrate inside a Zircalloy container. The internal void volume of TU-2 and TU-3, with the inner container, is $81.1 \mathrm{~cm}^{3}\left(4.95 \mathrm{in}^{3}\right)$. 


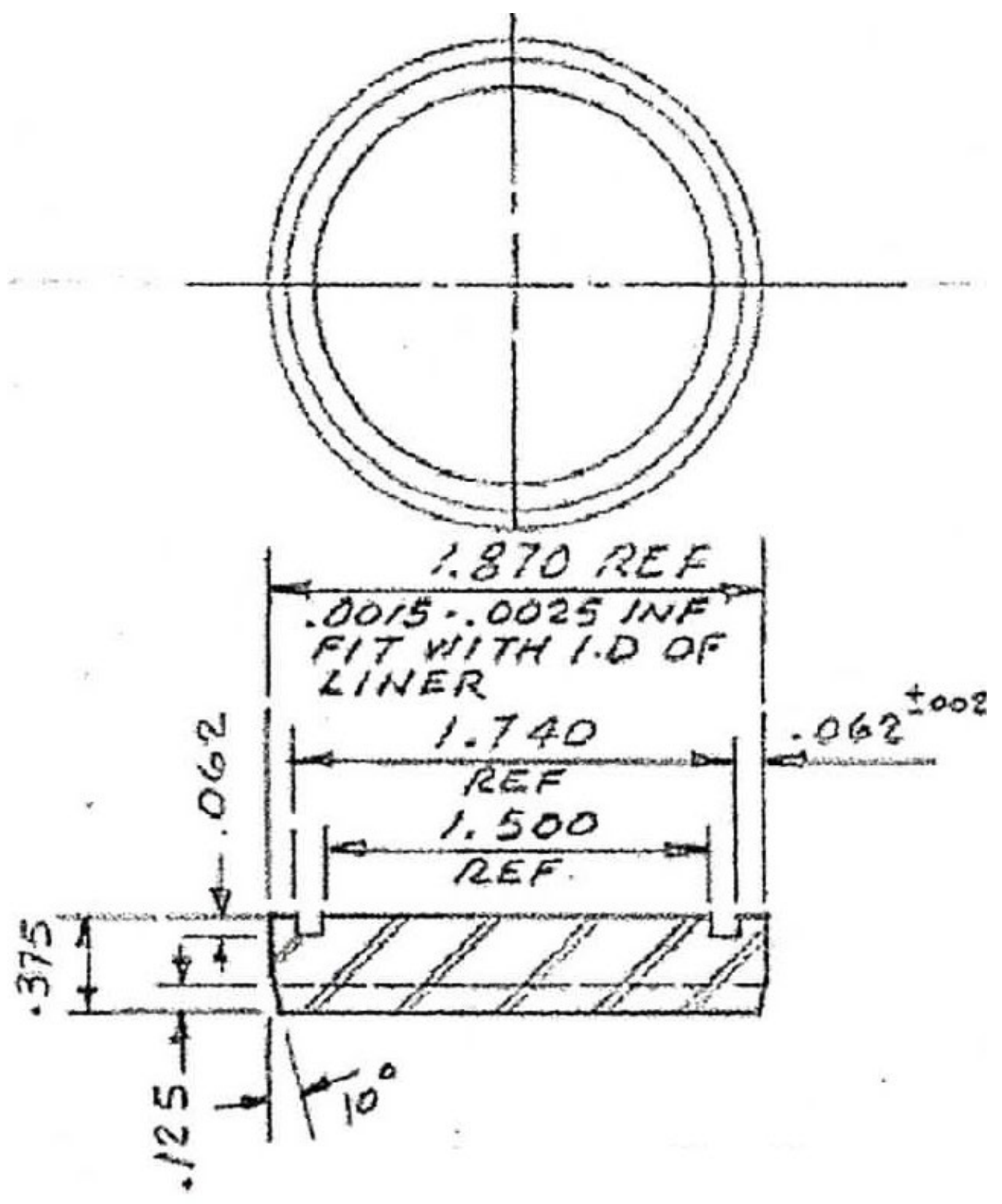

Figure 1-1. Top view of the ORNL-SFC-W-1 SFC. 
All test units were tested for leak tightness (leak test) before and after each test outlined in the test plan, "Test Plan for the Special Form Qualification Testing of the Mark 42 Pu Powder Special Form Capsule" (ORNL/NTRC-084). The testing requirements for each test unit are described below.

Specimen TU-1 was subjected to leak testing, impact testing, and percussion testing. After each specified test, a leak test of the specimen was performed. See Table 1.1 for the TU-1 test sequence.

Leak Test - 49 CFR 173.469 (a)(4)(i): The leak test performed was to demonstrate a leak tightness of $10^{-4}$ torr $^{-1} / \mathrm{s}\left(1.3 \times 10^{-4} \mathrm{~atm}-\mathrm{cm}^{3} / \mathrm{s}\right)$ based on air at $25^{\circ} \mathrm{C}\left(77^{\circ} \mathrm{F}\right)$ and one atmosphere differential for solid radioactive content.

Impact Test - 49 CFR 173.469 (b)(1): The specimen was dropped onto a target from a height of $9 \mathrm{~m}$ $(30 \mathrm{ft})$ or greater. This target met the requirement specified in Sec. 173.465(c)(5). According to 49 CFR 173.469 (a)(2), the specimen may not break or shatter when subjected to the impact test.

Percussion Test - 49 CFR 173.469 (b)(2)(i). The specimen was placed on a sheet of lead that was supported by a smooth solid surface and was struck by the flat face of a steel billet so as to produce an impact equivalent to that resulting from a free drop of $1.4 \mathrm{~kg}(3 \mathrm{lb})$ through $1 \mathrm{~m}(3.3 \mathrm{ft})$.

(ii) The flat face of the billet was $2.5 \mathrm{~cm}$ (1 in.) in diameter, with the edges rounded off to a radius of $3 \mathrm{~mm} \pm 0.3 \mathrm{~mm}$ (0.12 in. \pm 0.012 in.).

(iii) The lead had a hardness number with values within the range of 3.5 to 4.5 on the Vickers scale and a thickness of $2.5 \mathrm{~cm}$ ( 1 in.) or greater, and it covered an area greater than that covered by the specimen.

(iv) The specimen was placed on a fresh surface of lead for the impact test.

(v) The billet struck the specimen so as to cause maximum damage.

49 CFR 173.469 (a)(2) specifies that the specimen may not break or shatter when subjected to the percussion test.

Specimens TU-2 and TU-3 were subjected to leak testing and heat testing. Leak tests of TU-2 and TU-3 were performed before and after the heat tests per the criteria described in 49 CFR 173.469 (b)(4). See Table 1.1 and Table 1.2 for the TU-2 and TU-3 test sequences.

The ORNL-SFC-W-1 SFC was fabricated from an ASTM A511/A269 stainless-steel liner (body) - a right cylinder with an outside diameter of $2 \mathrm{in}$. and wall thickness of $0.065 \mathrm{in}$. welded at the top and bottom to plugs made from 304L/304 stainless-steel bar. Details of the dimensions can be found in APPENDIX A, Figure 1-1, and Figure 1-2. The isometric view of the test unit is shown in Figure 1-3 with sample identification markings. 


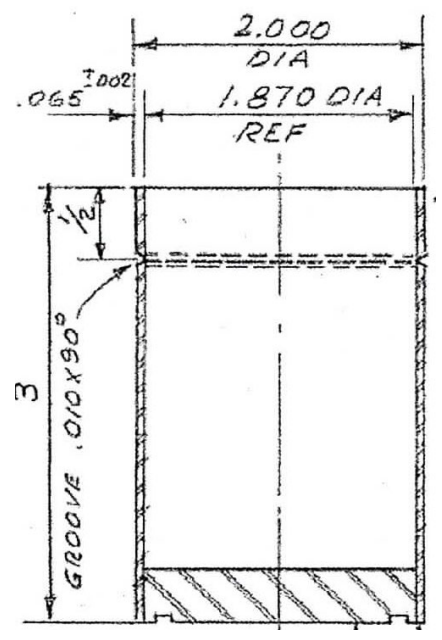

Figure 1-2. Side assembly view.

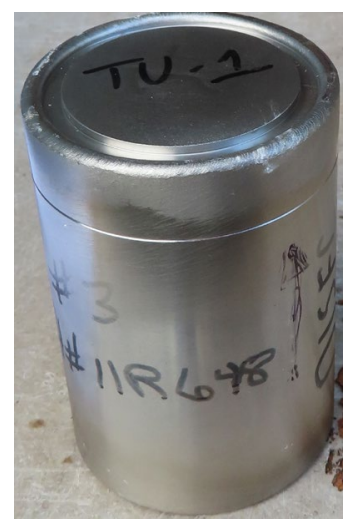

Figure 1-3. ORNL-SFC-W-1 SFC test unit.

\subsection{DESCRIPTION OF QUALITY ASSURANCE ACTIVITIES}

The ORNL Quality Assurance Program Description (QAPD) addresses the criteria requirements identified in DOE Order 414.1D, Quality Assurance, and 10 CFR 830.122, Quality Assurance Criteria. Quality principles and methodologies are integrated and flowed down by management systems within the ORNL Standards Based Management System (SBMS).

ORNL's PTP Quality Assurance Program is under the direction of the Reactor and Nuclear Systems Division. All testing performed by the PTP is conducted under the PTP Quality Assurance Program Plan, PTP-QA-001/NTRC-PRF-QAP-001, Rev. 3., Integrated Document Management System ID 018050.

49 CFR 173.469, "Special Form Performance Testing," is documented by ORNL's test plan, Test Plan for the Special Form Qualification Testing of the Mark 42 Pu Powder Special Form Capsule (ORNL/NTRC-084, Rev.0, available upon request).

The safety aspects of the activities described in this test plan are controlled by ORNL's Research Hazard Assessment and Control (RHAC) Research Safety Summary (RSS), General Use and Package Testing Activities Conducted in the NTRC Packaging Research Facility (1082). 


\subsection{ORNL-SFC-W-1 SFC TEST MATRIX}

All three specimens were tested following the sequence listed in Table 1.1 and Table 1.2.

Table 1.1. Sequence of tests and processes for the ORNL-SFC-W-1 SFC TU-1

\begin{tabular}{|c|c|c|c|c|}
\hline Sequence & Test title & $\begin{array}{l}\text { Reference / } \\
\text { Acceptance }\end{array}$ & $\begin{array}{l}\text { Procedures or test } \\
\text { forms(s) }\end{array}$ & Comments \\
\hline 1 & Leak test & $\begin{array}{l}49 \text { CFR } \\
173.469(a)(4)(i)\end{array}$ & NDE-70 Rev.7 & $\begin{array}{l}10^{-4} \text { torr }{ }^{-1} / \mathrm{s}\left(1.3 \times 10^{-4} \mathrm{~atm}-\mathrm{cm}^{3} / \mathrm{s}\right) \\
\text { based on air at } 25^{\circ} \mathrm{C}\left(77^{\circ} \mathrm{F}\right) \text { and one } \\
\text { atmosphere differential pressure for } \\
\text { solid radioactive content. }\end{array}$ \\
\hline 2 & Impact test & $\begin{array}{l}49 \text { CFR } \\
173.469(b)(1)\end{array}$ & $\begin{array}{l}\text { PTP-PRF-10, Rev. } 5 \\
\text { Procedure Checklist and } \\
\text { PTP-PRF-10, Rev. } 5 \\
\text { Data Sheet }\end{array}$ & $\begin{array}{l}\text { Drop from a height of } 9 \mathrm{~m}(30 \mathrm{ft}) \text { or } \\
\text { greater. } \\
\text { Vertical top down. }\end{array}$ \\
\hline 3 & Leak test & $\begin{array}{l}49 \text { CFR } \\
173.469(a)(4)(i)\end{array}$ & NDE-70 Rev.7 & $\begin{array}{l}10^{-4} \text { torr }-1 / \mathrm{s}\left(1.3 \times 10^{-4} \mathrm{~atm}-\mathrm{cm}^{3} / \mathrm{s}\right) \\
\text { based on air at } 25^{\circ} \mathrm{C}\left(77^{\circ} \mathrm{F}\right) \text { and one } \\
\text { atmosphere differential pressure for } \\
\text { solid radioactive content. }\end{array}$ \\
\hline 4 & $\begin{array}{l}\text { Percussion } \\
\text { test }\end{array}$ & $\begin{array}{l}49 \text { CFR } \\
173.469(b)(2)\end{array}$ & $\begin{array}{l}\text { NTRC/ORNL-084 Rev. } 0 \\
\text { Test Form } 1\end{array}$ & $\begin{array}{l}\text { Free drop of } 1.4 \mathrm{~kg} \text { ( } 3 \text { pounds) } \\
\text { through } 1 \mathrm{~m}(3.3 \mathrm{ft}) . \text { Vertical top up }\end{array}$ \\
\hline 5 & Leak test & $\begin{array}{l}49 \text { CFR } \\
173.469(a)(4)(i)\end{array}$ & NDE-70 Rev.7 & $\begin{array}{l}10^{-4} \text { torr- } 1 / \mathrm{s}\left(1.3 \times 10^{-4} \mathrm{~atm}-\mathrm{cm}^{3} / \mathrm{s}\right) \\
\text { based on air at } 25^{\circ} \mathrm{C}\left(77^{\circ} \mathrm{F}\right) \text { and one } \\
\text { atmosphere differential pressure for } \\
\text { solid radioactive content. }\end{array}$ \\
\hline
\end{tabular}

Table 1.2. Sequence of tests and processes for the ORNL-SFC-W-1 SFC TU-2 and TU-3

\begin{tabular}{|c|c|c|c|c|}
\hline Sequence & Test title & Reference & $\begin{array}{l}\text { Procedures or test } \\
\text { forms(s) }\end{array}$ & Comments \\
\hline 1 & Leak test & $\begin{array}{l}49 \text { CFR } \\
173.469(a)(4)(i)\end{array}$ & NDE-70 Rev.7 & $\begin{array}{l}10^{-4} \text { torr- } 1 / \mathrm{s}\left(1.3 \times 10^{-4} \mathrm{~atm}-\mathrm{cm}^{3} / \mathrm{s}\right) \\
\text { based on air at } 25^{\circ} \mathrm{C}\left(77^{\circ} \mathrm{F}\right) \text { and one } \\
\text { atmosphere differential pressure for } \\
\text { solid radioactive content. }\end{array}$ \\
\hline 2 & Heat test & 49 CFR 469(b)(4) & $\begin{array}{l}\text { NTRC/ORNL- } 084 \\
\text { Rev. } 0 \\
\text { Test Form } 2 \\
\text { Test Form } 3 \\
\text { Test Form } 4\end{array}$ & $\begin{array}{l}\text { ORNL-SFC-W-1 SFC held above } \\
825^{\circ} \mathrm{C}\left(1517^{\circ} \mathrm{F}\right) \text { for } 10 \mathrm{~min} \text { See } \\
\text { Figure } 3-6 \\
\text { See APPENDIX B }\end{array}$ \\
\hline 3 & Leak test & $\begin{array}{l}49 \text { CFR } \\
173.469(a)(4)(i)\end{array}$ & NDE-70 Rev.7 & $\begin{array}{l}10^{-4} \text { torr }-1 / \mathrm{s}\left(1.3 \times 10^{-4} \mathrm{~atm}-\mathrm{cm}^{3} / \mathrm{s}\right) \\
\text { based on air at } 25^{\circ} \mathrm{C}\left(77^{\circ} \mathrm{F}\right) \text { and one } \\
\text { atmosphere differential pressure for } \\
\text { solid radioactive content. }\end{array}$ \\
\hline
\end{tabular}




\subsection{TEST DATA RECORDS}

This report documents the tests performed and measurements observed from the ORNL-SFC-W-1 SFC testing. The general data types for these tests are (1) manually derived measurements and observations, (2) digital still photography, and (3) video recording of the drop and percussion tests.

The primary recording media for each of the general types of data are (1) procedure checklists, data sheets and test forms for data, measurements, and observations; (2) computer files (JPG format) of the digital photography; and (3) computer files (MPG format) of the video recordings.

The completed data sheets and procedure checklists have been scanned into a digital format and are available upon request. Photographs are presented in the main body of this document as appropriate.

\subsection{DEVIATIONS FROM THE TEST PLAN}

Per the test plan (ORNL/NTRC-084), 3 test units were subjected to the pre-testing leak test. TU-1 was later tested as originally specified in the test plan (see Table 1.1). TU-2 and TU-3 were tested as specified in the original test plan (see Table 1.2). There was no deviation from the original test plan.

\section{PRE-TEST ACTIVITIES}

The test units were delivered in a ready-to-test condition, so there were no specific pretest activities.

\section{SPECIAL FORM TESTS}

Calibrated equipment was used when required. Calibration controls were per PTP-QA-13, Control of Measuring and Test Equipment. The test equipment calibration IDs and calibration due dates were recorded on the test data sheets as applicable.

\section{Test Equipment:}

Drop pad: The-outdoor drop pad facility located at the NTRC was used for the impact test. This drop pad facility consists of a massive steel plate set on top of rebar and concrete. The mass of the outdoor drop pad has a steel impact surface and mass in excess of 140 tons. The documentation of the pad construction and suitability for use is provided in Design and Certification of Targets for Drop Testing at the NTRC Package Research Facility Rev. 0, May 2003 (ORNL/NTRC-001).

Billet: The billet for the percussion test is made of 1-inch diameter steel according to the requirements stated in 49 CFR 173.469(b)(2). The diameter and weight of the billet were verified and recorded in the test record forms (see Appendix B) before testing using a calibrated caliper and scale. The billet has a threaded hole at one end into which a screw-eye is attached for rigging purposes.

Platform scale: A Mettler-Toledo scale (property number A000593, model number XP32001LDR, serial number 1129350702) was used to measure the mass of the percussion billet.

$30 \mathrm{ft}$ plumb bob: The $9 \mathrm{~m}(30 \mathrm{ft})$ measurement wire was used to establish the height of the test unit for the impact test. Its length was verified to be in excess of $30 \mathrm{ft}$ before the tests using a calibrated tape measure. 
$1 \mathbf{m}$ aluminum rod: The $1 \mathrm{~m}$ aluminum rod (property number A001146) was used to verify the minimum height of the test unit above the impact surface (lead sheet) prior to the percussion test. This rod's calibration is current until 6/30/2021.

Rigging: All standard rigging used includes a current inspection sticker.

Helium leak test: Helium leak test and pressure test equipment were provided by the ORNL Level III leak test and ORNL Facilities and Operations personnel. Calibrated leaks were used to calibrate leak test equipment as part of the leak test procedure.

Furnace: The furnace used for the heat test was located in the ORNL High Bay Core Facility, Room 131, Bldg. 4508. The furnace used was a RAD-O-GLOW Global Furnace (Model \#RG-3010G-2, Serial No. R2-717, ORNL property number X183717), as shown in Figure 3-4. The furnace controller thermocouple was calibrated prior to testing. The calibration record was recorded in the test form.

Thermocouple data system: The thermal data system used was the PTP Compact Data Acquisition (cDAQ) system (property number M303131). Furnace temperature readings were automatically recorded every 5 seconds. The calibration records of the cDAQ thermal data system and thermocouples were recorded on the test forms, and copies are included in the APPENDIX F.

\section{$3.19 \mathrm{~m}(30 \mathrm{ft})$ IMPACT TEST}

The impact test was performed using the outdoor drop pad at the NTRC north parking lot next to L110. This test was performed according to Procedure PTP-PRF-10, Rev. 6, dated 1-31-19.

TU-1 was raised to a minimum height of $9 \mathrm{~m}$ (30ft) using a man lift. A drop test fixture was used to set the drop orientation of the capsule (see Figure 3-1). The drop orientation of TU-1 was vertical top down, as stated in the test plan. Engineering judgement was used to choose the vertical top down orientation, which will cause direct damage to the threaded joint between the lid and body of the test unit. This joint is the most vulnerable feature of the design for the impact test. This orientation ensures that the impact causes maximum damage to the test unit. The test unit was released and allowed to free fall and impact onto the outdoor NTRC drop pad. The impact resulted in minor scuff marks on the impact area of the capsule. The capsule met the acceptance criteria of not shattering or breaking as a result of the impact.

After the 30-ft impact test, TU-1 was subjected to a leak test using 49 CFR 173.469 (a)(4)(i). Results of this leak test are documented in the leak rate test procedure in Section 3.3.

After a successful leak rate test, TU-1 was subjected to a percussion test per the test plan. This test was performed on the indoor drop pad at the NTRC, room L110. The procedure (ORNL/NTRC-084) for the percussion test can be found in the approved test plan. The setup was as shown in Figure 3-2. 


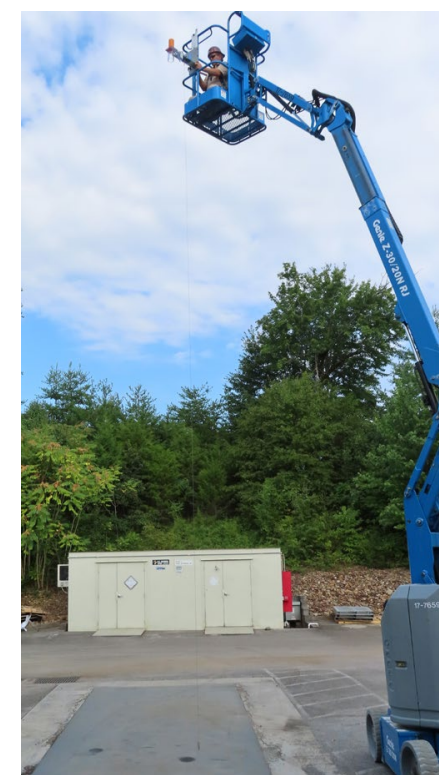

Man-lift at $30 \mathrm{ft}$ height

determined using the plum bob
Drop apparatus set up, horizontal level within $2^{\circ}$

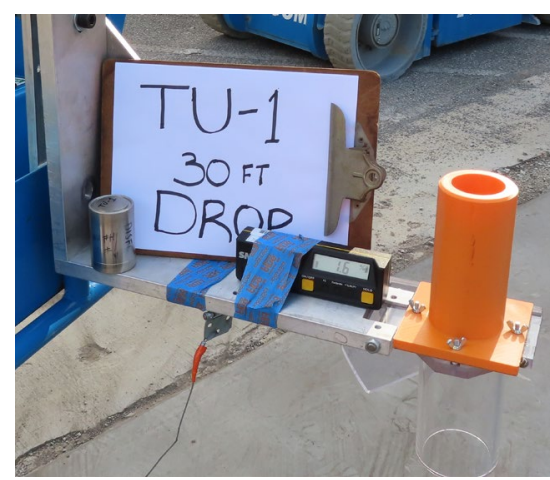

Figure 3-1. TU-1 9 m (30 ft) impact test.

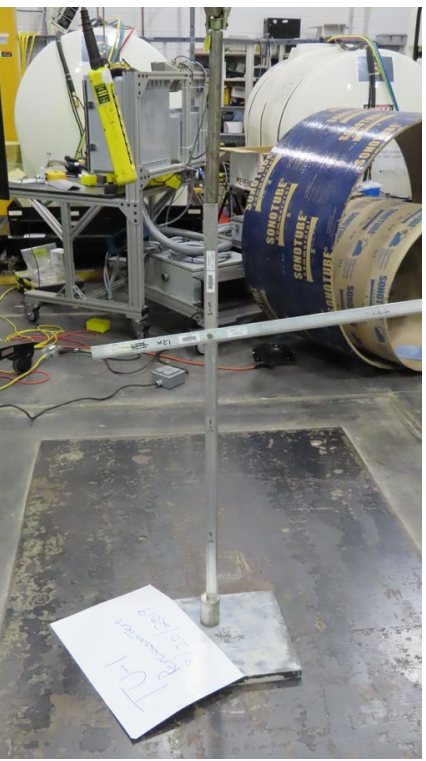

Lead Sheet

Unyielding Surface

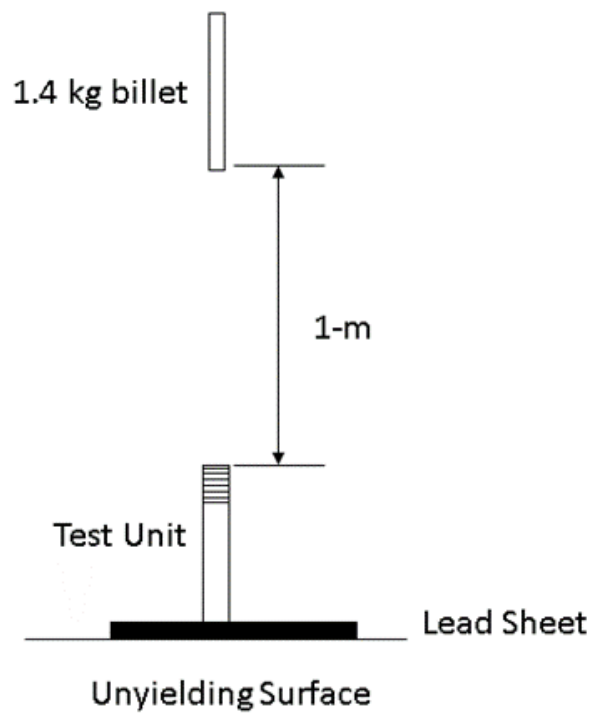

TU-1 impact point

and imprint on pad

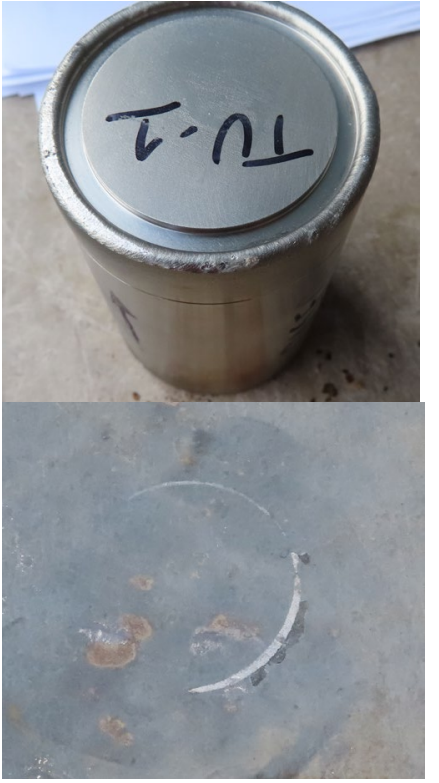

(a)

(b)

Figure 3-2. Percussion test setup.

When released, the billet impacted TU-1 squarely on the top surface of the capsule. There was no discernible deformation or damage to the capsule as a result of the percussion test, though there was an impact scuff mark. Figure 3-3 photos show TU-1 before and after the percussion test. 


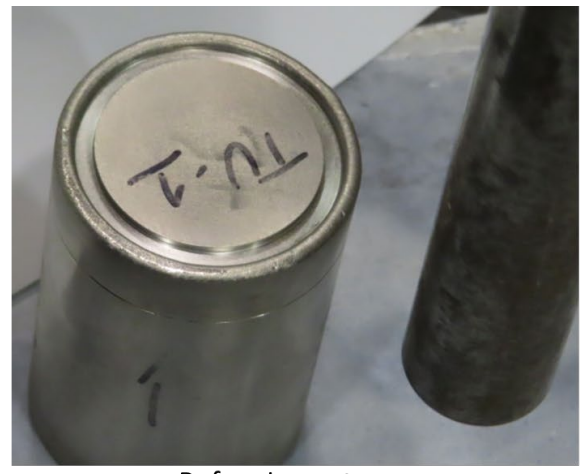

Before Impact

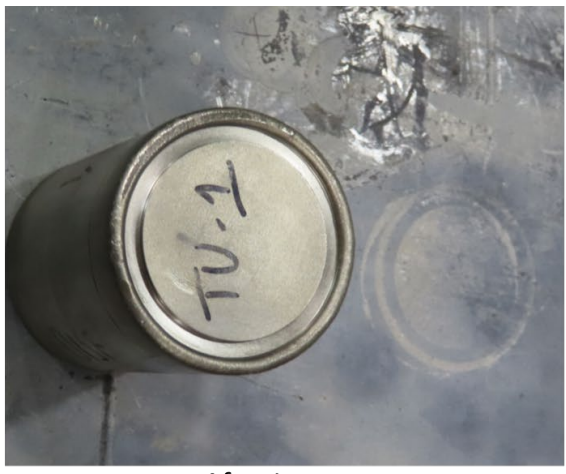

After Impact

Figure 3-3. Before and after percussion test of TU-1 (note billet impact point above letter "T").

After the percussion test, TU-1 was subjected to a leak test according to the test plan using $49 \mathrm{CFR}$ 173.469 (a)(4)(i). Results of this leakage test are documented in the leak rate test procedure in Section 3.3 .

\subsection{HEAT TEST}

The 49 CFR 173.469(b)(4) heat test was performed on TU-2 and TU-3. This heat test was performed in ORNL Bldg. 4508 in accordance with the test procedure detailed in the test plan (ORNL/NTRC-084 Rev. 0 ). The results are recorded on Test Forms 2, 3, and 4 in Appendix B of this test report.

The safety aspects of activities for this heat test are controlled by ORNL Research Hazard Analysis and Control System (RHACS) RSS 336.22, Materials Processing/Refining at Bldg. 4508. The furnace used was a RAD-O-GLOW Global Furnace (Model \#RG-3010G-2, Serial No. R2-717, ORNL property number X183717), as shown in Figure 3-4.

The furnace has a temperature range of $648.89-1537.78^{\circ} \mathrm{C}\left(1,200-2,800{ }^{\circ} \mathrm{F}\right)$. The furnace has two calibrated controllers: over-temp and temp control. Two calibrated (calibration date: 11-12-2018) Type K thermocouples (TCs) (ID: Delta M. Corp Type K) were inserted into the furnace-one at the top of the furnace to the center, and the other through the front of the furnace. These thermocouples were then connected to an ORNL-developed thermal data acquisition system (cDAQ model \# M303131 calibration due date: 11-12-2019) shown in Figure 3-5.
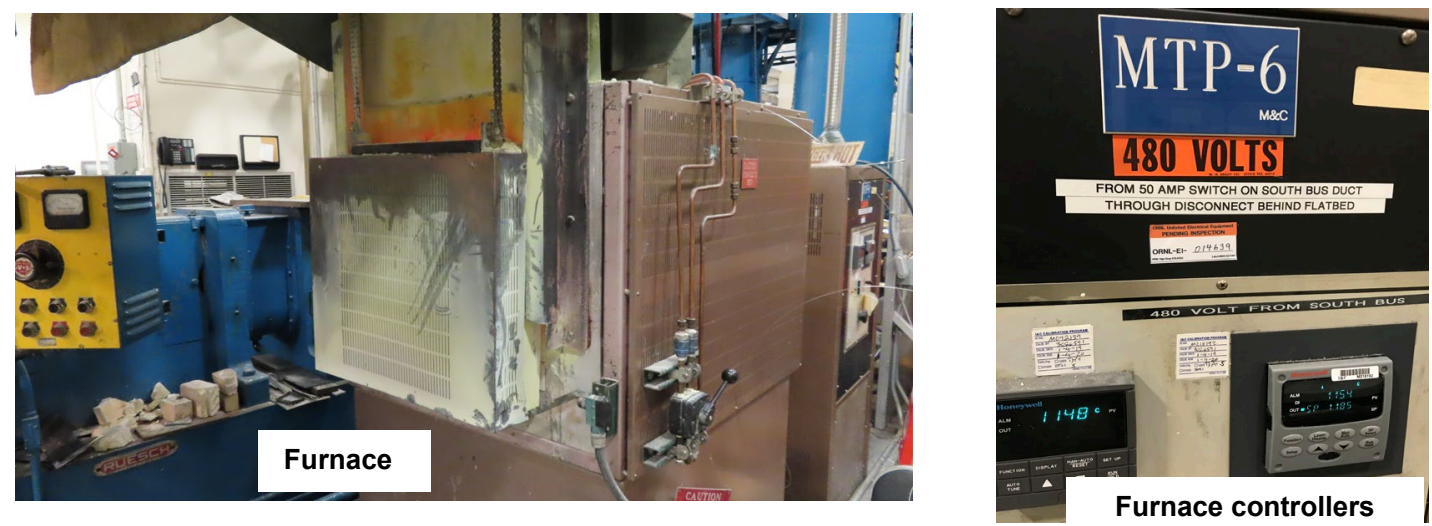

Figure 3-4. The RAD-O-GLOW furnace used for ORNL-SFC-W-1 capsules thermal test.

The PTP computer-based thermal monitoring system was used to monitor the furnace environment during the test. This system provides 48 data channels that can be continuously logged to a data file (Figure 3-5); 
only two of these channels were used as specified in the test plan. The TCs were then connected to the PTP DAQ, which transferred temperature data to the laptop via an ethernet cable. During the test runs, the system was set to $\log$ data every 5 seconds from each data channel. The TCs used for TU-2 and TU-3 thermal testing were calibrated 0.062-inch diameter Type K TCs that were $50 \mathrm{ft}$ in length. These lightweight TCs provided a very rapid response to changes in temperature, which in turn provided a very accurate picture of the furnace and test unit thermal behavior.
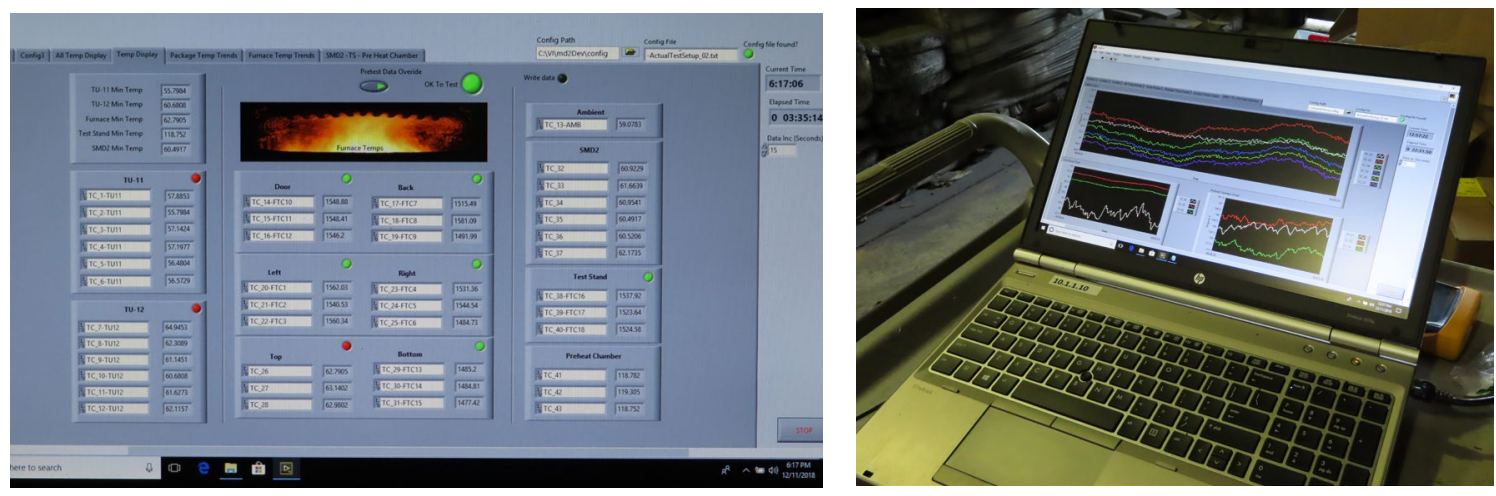

Figure 3-5. ORNL cDAQ system.

The furnace was preheated to a temperature above $850^{\circ} \mathrm{C}\left(1562^{\circ} \mathrm{F}\right)$ for three hours. After a three-hour heat soaking period at a constant temperature above $850^{\circ} \mathrm{C}\left(1562^{\circ} \mathrm{F}\right)$, the furnace door was opened, and TU-2 was inserted into the furnace cavity. The furnace door was closed, and when both TCs reached a furnace reading above $825^{\circ} \mathrm{C}\left(1517^{\circ} \mathrm{F}\right)$, the 10 -minute thermal test was started (Figure 3-6). $\mathrm{TC} 1$ was at the center of the furnace, and TC2 was near the front door. The DAQ system provided continuous monitoring of the temperature profile, as shown in Figure 3-6. The temperature profile represents four distinct activities: (1) the furnace pre-heat period, (2) the TU-2 heating period, (3) another pre-heat period between TU-2 extraction and TU-3 insertion, and (4) the TU-3 insertion period. After a 10-minute period, the door was opened, and TU-2 was removed from the furnace and allowed to cool naturally. TU-3 was inserted into the furnace after the furnace temperature had been allowed to reach a temperature greater $825^{\circ} \mathrm{C}\left(1517^{\circ} \mathrm{F}\right)$. The furnace door was closed, and when both TCs reached a furnace reading above $825^{\circ} \mathrm{C}\left(1517^{\circ} \mathrm{F}\right)$, the 10 -minute thermal test for TU-3 was started. Figure 3-7 and Figure 3-8 show the units before and after the heat tests. After the thermal tests, the test units were subjected to the helium leak test and the bubble test.

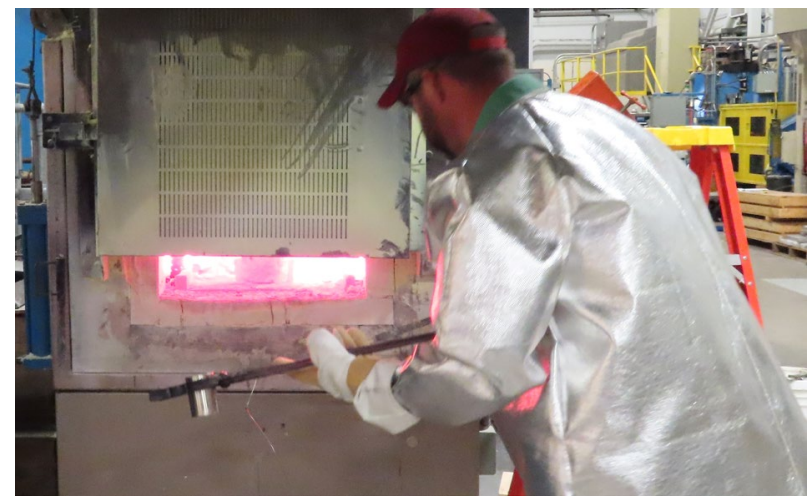

Figure 3-6. TUs were carefully loaded into the furnace. 


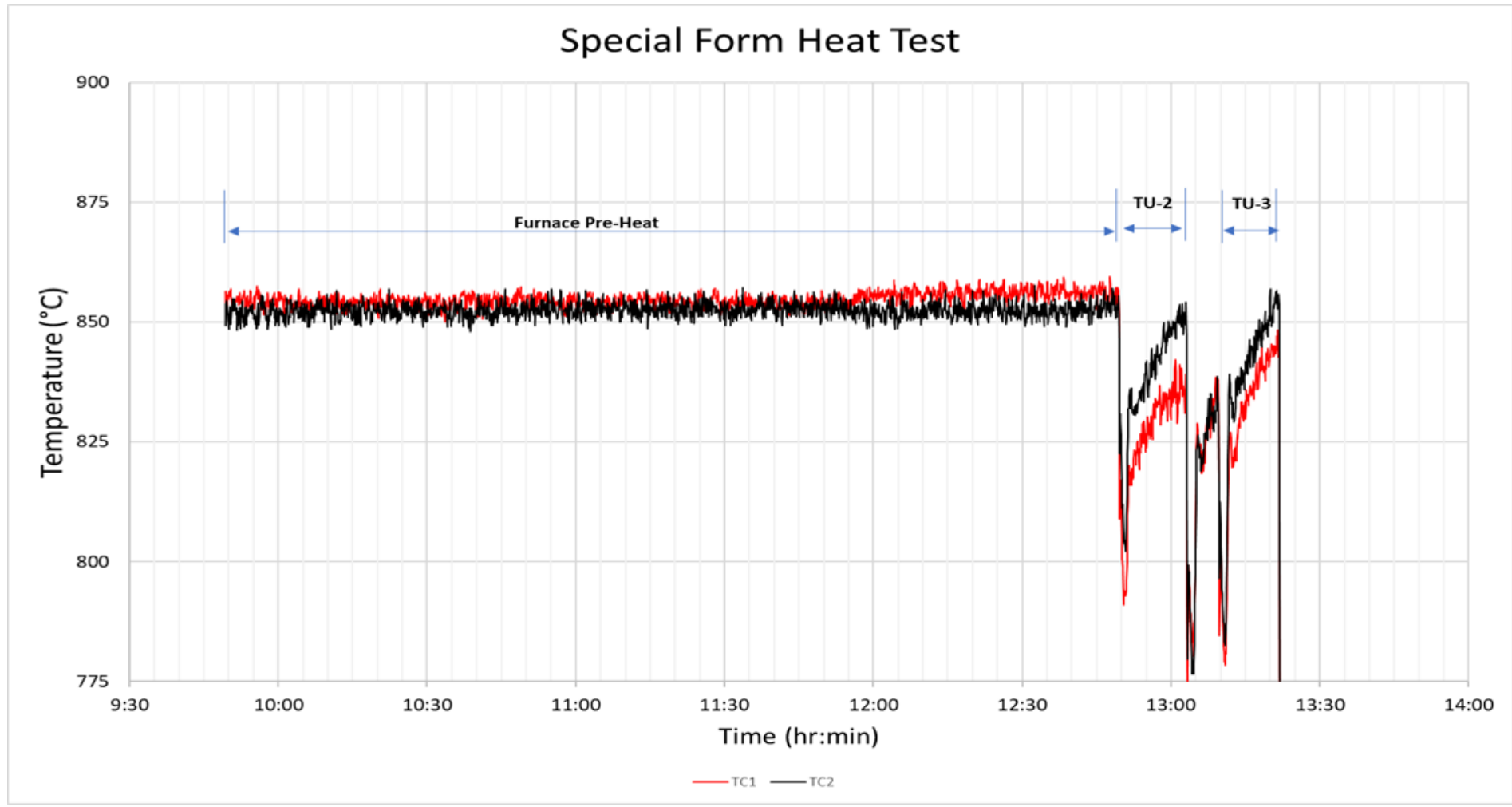

Figure 3-7. Pre-heat and heat test temperature profile.
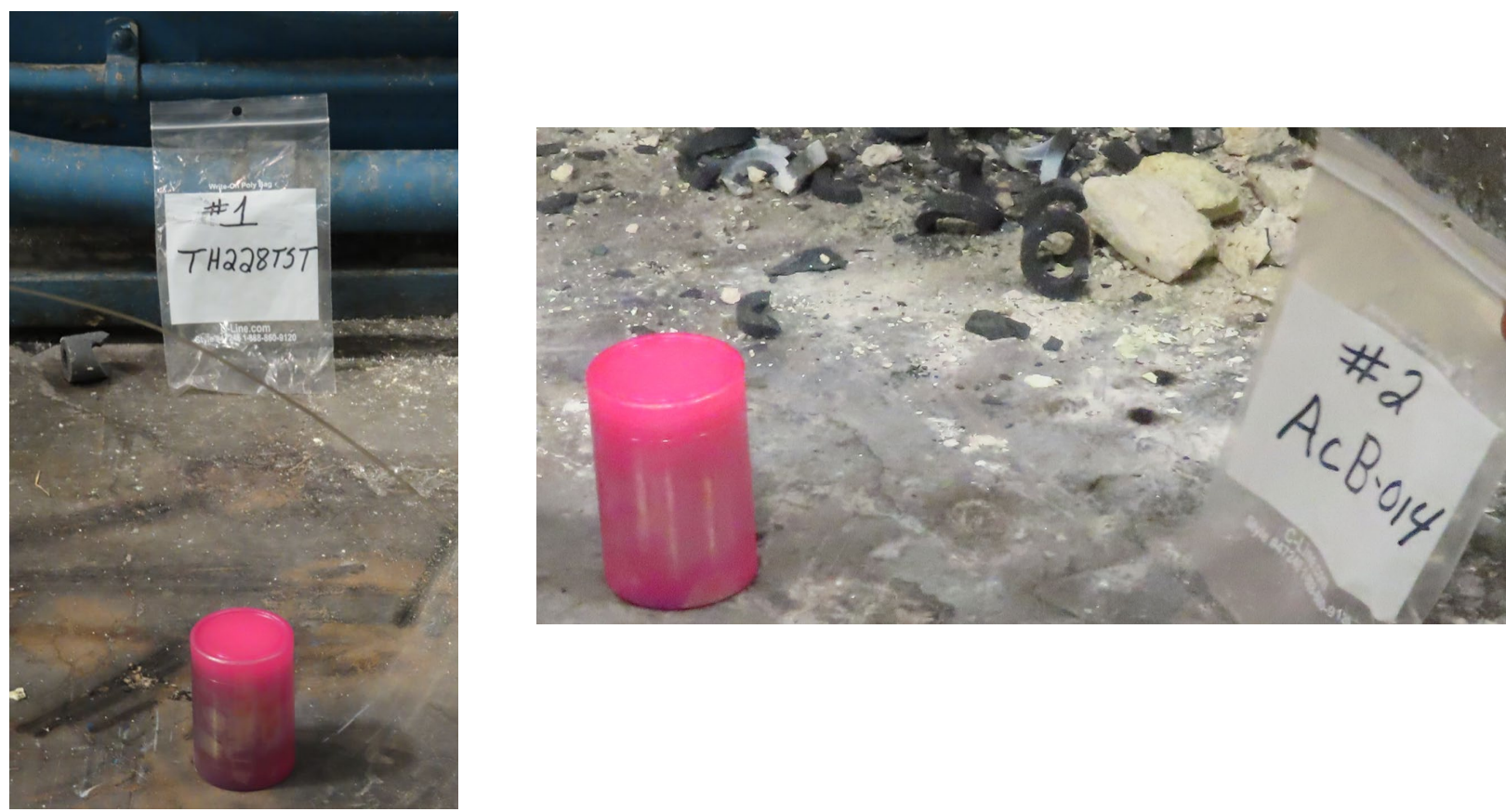

Figure 3-8. TU-2 and TU-3 post-heat test results. 


\subsection{LEAK RATE TESTING}

\subsubsection{Evacuated Envelope (with Back Pressurization)}

Leak rate tests that met the test requirements of 49 CFR 173.469 (a)(4)(i) were performed individually on each test unit before and after each special form test. The leak rate tests were performed according to ANSI N14.5-2014 American National Standard for Radioactive Materials - Leakage Tests on Packages for Shipment, Table A.1, Test Description A.5.5, "Evacuated Envelope (with back pressurization)" and Test Description A.5.6 "Gas bubble techniques." The ANSI document states that the back-pressure method ". . . is ideal for welded capsules from very small sizes up to the sizes limited by the dimensions of the pressurizing chamber," and that the "nominal test sensitivity $=10^{-3}-10^{-8} \mathrm{ref}-\mathrm{cm} / \mathrm{s}$ " and the bubble test method are used for hermetically sealed test specimens.

Section A.5.5 of ANSI N14.5-1997, Evacuated Envelope with Helium Back Pressure references ASTM E 493, Standard Test Methods for Leaks Using the Mass Spectrometer Leak Detector in the Inside-Out Testing Mode. This standard provides the method for converting a measured leak rate using the evacuated envelope with the helium back-pressure method into the standardized leak rate that must be compared to the pass/fail criteria specified in 49 CFR 173.469 (a)(4)(i), which is $10^{-4}$ torr- $1 / \mathrm{s}\left(1.3 \times 10^{-4} \mathrm{~atm}-\mathrm{cm}^{3} / \mathrm{s}\right)$.

The equation provided in Section 11.1.9 of ASTM E493 is as follows:

$$
\mathrm{S}_{1}=\left(\mathrm{P}_{\mathrm{e}} / \mathrm{P}_{\mathrm{a}}\right) \times\left(1-\mathrm{e}^{\left(-3600 * \mathrm{a}^{*} \mathrm{~T}\right)}\right) *\left(\mathrm{e}^{\left(-\mathrm{a}^{*} \mathrm{t}\right)}\right) \times \mathrm{L}
$$

where:

$$
\begin{aligned}
& \mathrm{S}_{1}=\text { indicated (measured) leak rate }(\mathrm{cc} / \mathrm{s}), \\
& \mathrm{P}_{\mathrm{e}}=\text { bombing pressure of helium (absolute), } \\
& \mathrm{P}_{\mathrm{a}}=\text { atmospheric pressure (absolute), } \\
& \mathrm{T}=\text { bombing time (hours), } \\
& \mathrm{t}=\text { waiting time between bombing and testing (s), } \\
& \mathrm{L}=\text { actual (standardized) leak rate (atm-cc/s), } \\
& \mathrm{a}=\mathrm{L} / \mathrm{V} \text { (where } \mathrm{V}=\text { internal volume), and } \\
& \mathrm{e}=2.71 \text { (natural logarithm). }
\end{aligned}
$$

Since $\mathrm{S}_{1}$ is being measured and the objective is to solve for $\mathrm{L}$, an iterative solver is required to find the solution. The equation was solved using Microsoft Excel. Note that the ASTM standard uses the term bombing, while the ANSI standard uses the term back-pressure. These terms are synonymous and are used interchangeably in this report.

TU-1, TU-2, and TU-3 were leak tested at ORNL by certified American Society for Nondestructive Testing (ASNT) Level II and Level III nondestructive testing (NDT) leak testing personnel using the NDE-70 R.7 procedure. See Appendixes D and E for documentation of leak tester certifications and the leak testing procedure. The test units were leak tested before and after each special form test. The test apparatuses used for these tests employed a spectrometer tuned to detect helium, a calibrated helium leak to calibrate the system, and two separate vessels - one vessel for helium back pressurization, and another vessel for the subsequent helium leakage rate testing under vacuum conditions. Figure 3-9 provides a schematic of the system used for helium back pressurization, and Figure 3-10 shows a schematic of the system used for the helium leakage rate test. Leak rate test variables and results for TU-1, TU-2 and TU-3 are shown in Table 3.1. A temperature correlation was performed to determine the measured leak rate at 
$25^{\circ} \mathrm{C}\left(77^{\circ} \mathrm{F}\right)$, and per the requirement, the standardized leak test result was less than the $1.0 \times 10^{-4}$ requirement for all the test units.

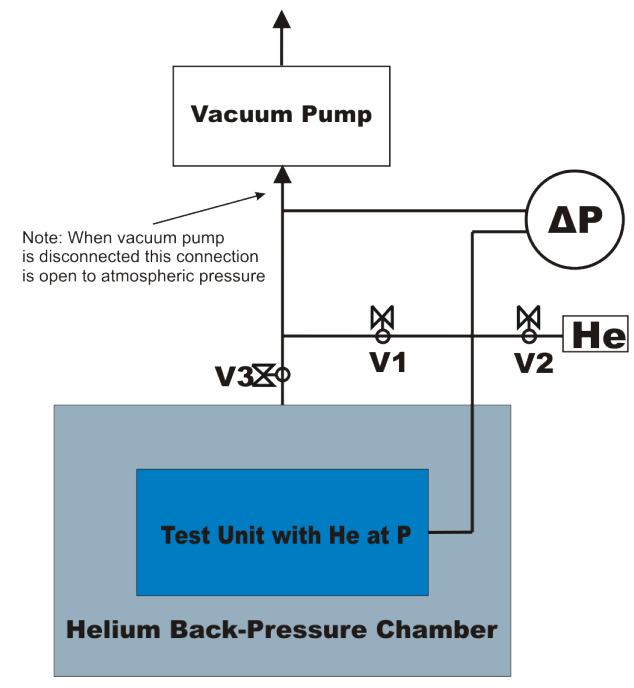

Figure 3-9. Diagram of helium back pressurization test.

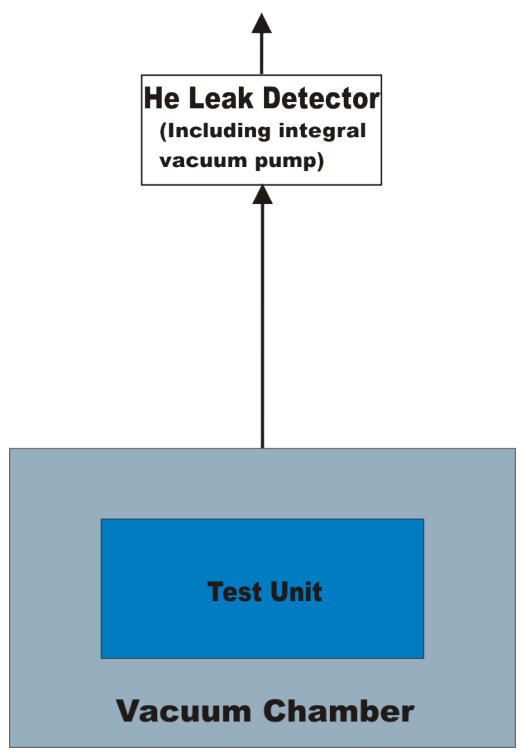

Figure 3-10. Diagram of helium leak testing system.

\subsubsection{Gas Bubble Techniques}

The gas bubble test was performed using the methods described in ANSI N14.5-2014, American National Standard for Radioactive Materials - Leakage Tests on Packages for Shipment, Table A.1, Test Description A.5.6 (b), "Vacuum Bubble." The method involves immersing the test unit in a liquid and then producing a vacuum above the liquid (e.g., water/glycol or isopropyl alcohol) in which the test item is submerged (see Figure 3-11). A leak is indicated by a stream of bubbles. This method applies to welded 
capsules. The nominal test sensitivity is $10^{-3} \mathrm{ref}-\mathrm{cm}^{3} / \mathrm{s}\left(10^{-4} \mathrm{~Pa}-\mathrm{m}^{3} / \mathrm{s}\right)$. Test units TU-1, TU-2 and TU-3 were bubble tested, and the results are presented in Table 3.2. See Appendixes D and E for documentation of leak tester certification and the leak testing procedure. While the sensitivity of the bubble test does not meet the minimum leak rate per 49 CFR 173.469 4(i), this test is needed because it is possible that a leak area is large enough that the helium inside the component may have evacuated out before the test unit is placed in the vacuum chamber for helium detection.

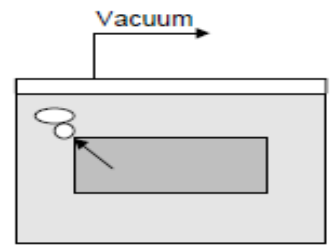

Figure 3-11. Vacuum bubble test.

Table 3.1. Leak rate test variables and results for TU-1, TU-2 and TU-3

\begin{tabular}{|c|c|c|c|c|c|c|c|}
\hline \multirow{3}{*}{ Parameter } & \multicolumn{7}{|c|}{ Test unit } \\
\hline & \multicolumn{3}{|c|}{ TU-1 } & \multicolumn{2}{|c|}{ TU-2 } & \multicolumn{2}{|c|}{ TU-3 } \\
\hline & Test 1 & Test 2 & Test 3 & Test 1 & Test 2 & Test 1 & Test 2 \\
\hline $\begin{array}{l}\text { Void space - } \\
\text { V (cc) }\end{array}$ & 75.9 & 75.9 & 75.9 & 81.2 & 81.1 & 81.2 & 81.1 \\
\hline $\begin{array}{l}\text { Bombing pressure - } \\
P_{\mathrm{e}} \text { (psig) }\end{array}$ & 30 & 30 & 30 & 30 & 30 & 30 & 30 \\
\hline $\begin{array}{l}\text { Atmospheric pressure - } \\
P_{a}(\text { psia })\end{array}$ & 14.69 & 14.69 & 14.69 & 14.69 & 14.69 & 14.69 & 14.69 \\
\hline Bombing time $-\mathrm{T}(\mathrm{hr})$ & 0.25 & 0.25 & 0.25 & 0.25 & 0.25 & 0.25 & 0.25 \\
\hline $\begin{array}{l}\text { Time between bombing and testing - } \\
\text { t (s) }\end{array}$ & $<3,600$ & $<3,600$ & $<3,600$ & $<3,600$ & $<3,600$ & $<3,600$ & $<3,600$ \\
\hline $\begin{array}{l}\text { Measured leak rate }(\mathrm{cc} / \mathrm{s})- \\
\mathrm{S}_{\mathrm{l}}(\mathrm{atm}-\mathrm{cc} \mathrm{He} / \mathrm{s})\end{array}$ & $<5.0 \times 10^{-7}$ & $<5.0 \times 10^{-7}$ & $<5.0 \times 10^{-7}$ & $<5.0 \times 10^{-7}$ & $<5.0 \times 10^{-7}$ & $<5.0 \times 10^{-7}$ & $<5.0 \times 10^{-7}$ \\
\hline $\mathbf{a}=\mathbf{L} / \mathbf{V}\left(\mathbf{s}^{-1}\right)$ & $1.56 \times 10^{-6}$ & $1.56 \times 10^{-6}$ & $1.56 \times 10^{-6}$ & $1.50 \times 10^{-6}$ & $1.50 \times 10^{-6}$ & $1.50 \times 10^{-6}$ & $1.50 \times 10^{-6}$ \\
\hline $\begin{array}{l}\text { Standardized leak rate - } \\
\mathrm{L}(\mathrm{atm}-\mathrm{cc} \mathrm{He} / \mathrm{s})\end{array}$ & $<1.18 \times 10^{-4}$ & $<1.18 \times 10^{-4}$ & $<1.18 \times 10^{-4}$ & $<1.22 \times 10^{-4}$ & $<1.22 \times 10^{-4}$ & $<1.22 \times 10^{-4}$ & $<1.22 \times 10^{-4}$ \\
\hline $\begin{array}{l}\text { Allowable leak rate - } \\
\text { (atm-cc } \mathrm{He} / \mathrm{s})\end{array}$ & $<1.3 \times 10^{-4}$ & $<1.3 \times 10^{-4}$ & $<1.3 \times 10^{-4}$ & $<1.3 \times 10^{-4}$ & $<1.3 \times 10^{-4}$ & $<1.3 \times 10^{-4}$ & $<1.3 \times 10^{-4}$ \\
\hline
\end{tabular}

Table 3.2. Bubble test results for TU-1, TU-2 and TU-3

\begin{tabular}{|c|c|c|c|c|c|c|c|}
\hline \multirow{3}{*}{ Parameter } & \multicolumn{7}{|c|}{ Test unit } \\
\hline & \multicolumn{3}{|c|}{ TU-1 } & \multicolumn{2}{|c|}{ TU-2 } & \multicolumn{2}{|c|}{ TU-3 } \\
\hline & Test 1 & Test 2 & Test 3 & Test 1 & Test 2 & Test 1 & Test 2 \\
\hline Bubble test pass/fail & pass & pass & pass & pass & pass & pass & pass \\
\hline
\end{tabular}




\section{CONCLUSION}

Three prototype ORNL-SFC-W-1 SFCs were subjected to the tests specified in 49 CFR 173.469. All the units were subjected to a pretest leak test. One unit was subjected to the impact test followed by a leak rate test and a percussion test, followed by another leak test. The other two units were subjected to the heat test followed by a leak rate test. Each unit met the leak rate criteria of $1.3 \times 10^{-4} \mathrm{~atm}-\mathrm{cm}^{3} / \mathrm{s}$ following each test. None of the test specimens broke or were shattered when subjected to the impact and percussion tests, and the specimens did not melt or disperse when subjected to the heat test. This testing process has shown that the design of the ORNL-SFC-W-1 SFC meets special form criteria per 49 CFR 173.469 and International Atomic Energy Agency (IAEA) special form requirements.

The ORNL-SFC-W-1 capsules welds (see APPENDIX C) were also examined after the completion of series of tests described above. 



\section{APPENDIX A. ORNL-SFC-W-1 SPECIAL FORM CAPSULE DRAWINGS}

Please note that the capsule named "Mark $42 \mathrm{Pu}$ " in the test records was renamed "ORNL-SFC-W-1" at the time of report writing. 



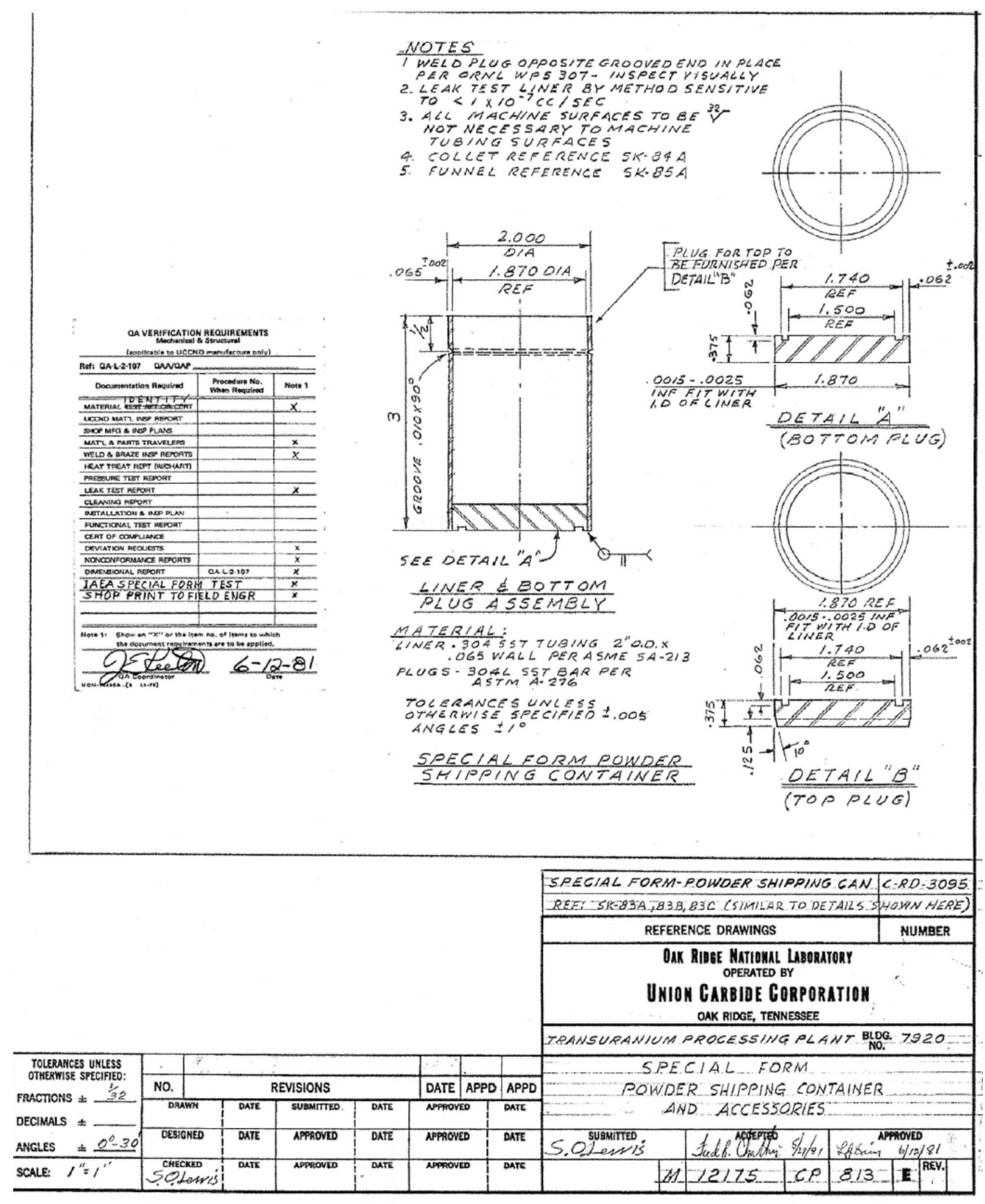

Figure A.4-1. ORNL-SFC-W-1 special form capsule engineering drawing. 



\section{APPENDIX B. TEST FORMS FOR ORNL-SFC-W-1 SPECIAL FORM CAPSULE}

Please note that the capsule named "Mark 42 Pu" in the test records was renamed "ORNL-SFC-W-1" at the time of report writing. 



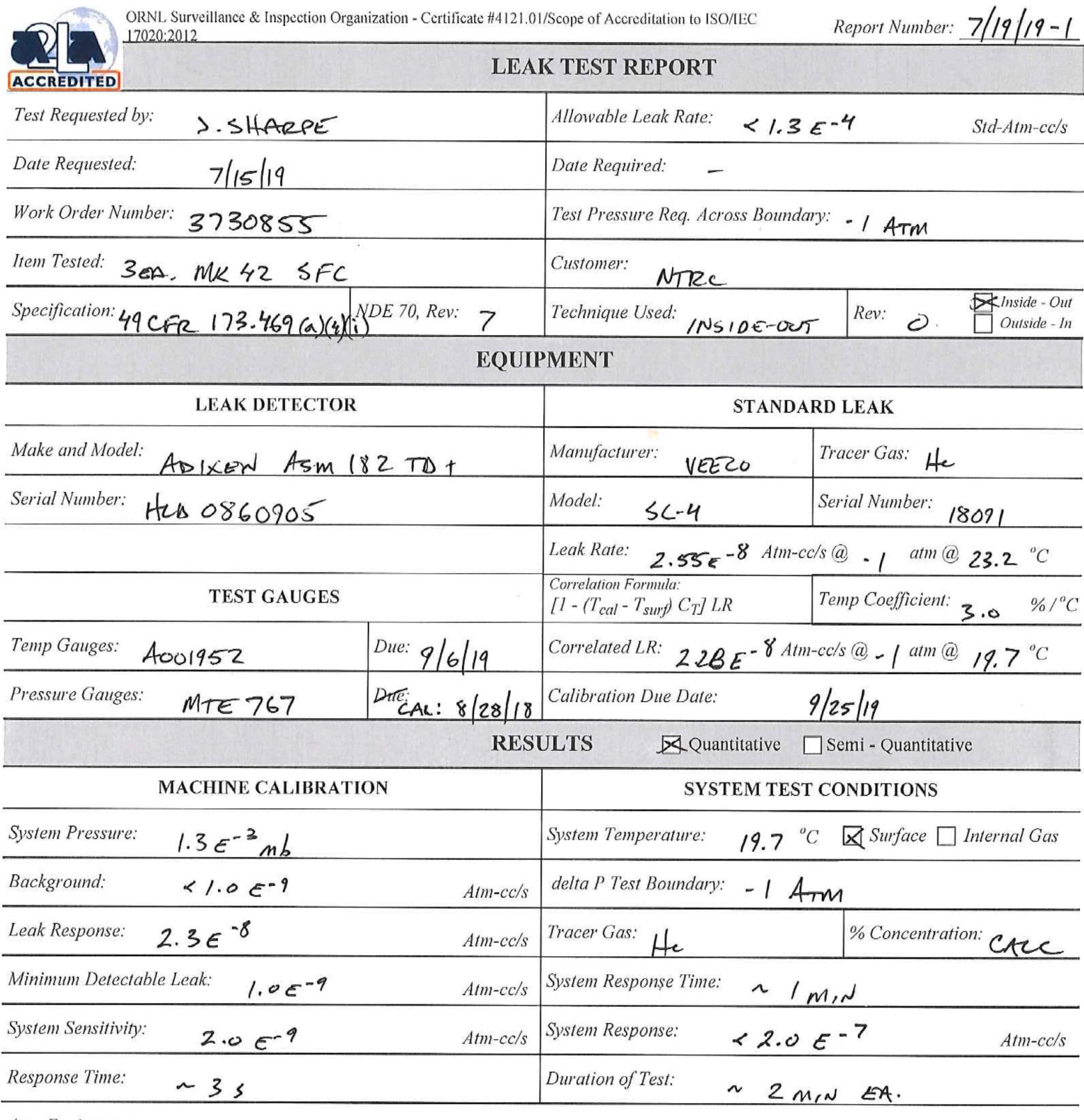

Aux. Equipment:

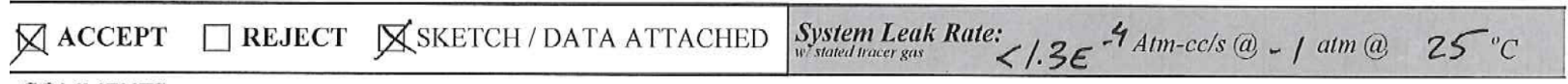
COMMENTS:

$$
\text { TU-1,TU-2,TU-3 LEAK TEST \#/ PER ORNL/NTRC-OS4 }
$$

$$
\text { FINE } \angle T
$$

E.VIOAC




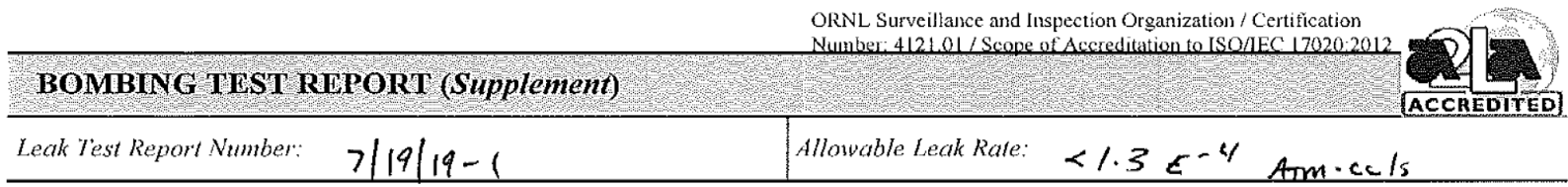

Hem(s) Tested: MK-42 SFC TU-1, TU-2, TU-3

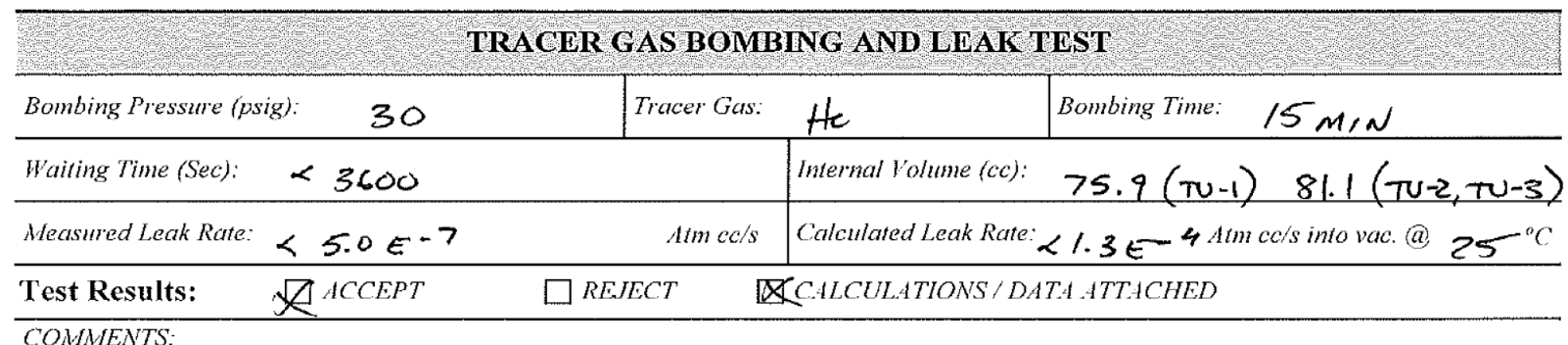

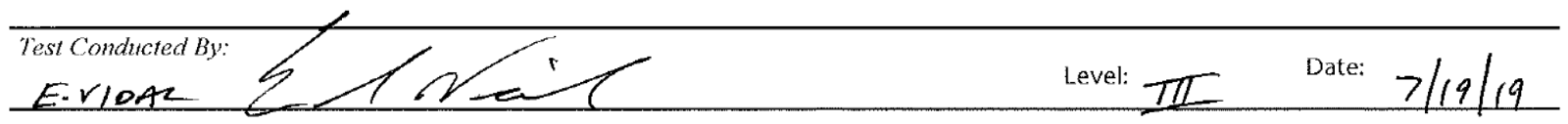

Form NDE 70-Bomb Rev.1 CN02

IDMS: 21078

B-4 


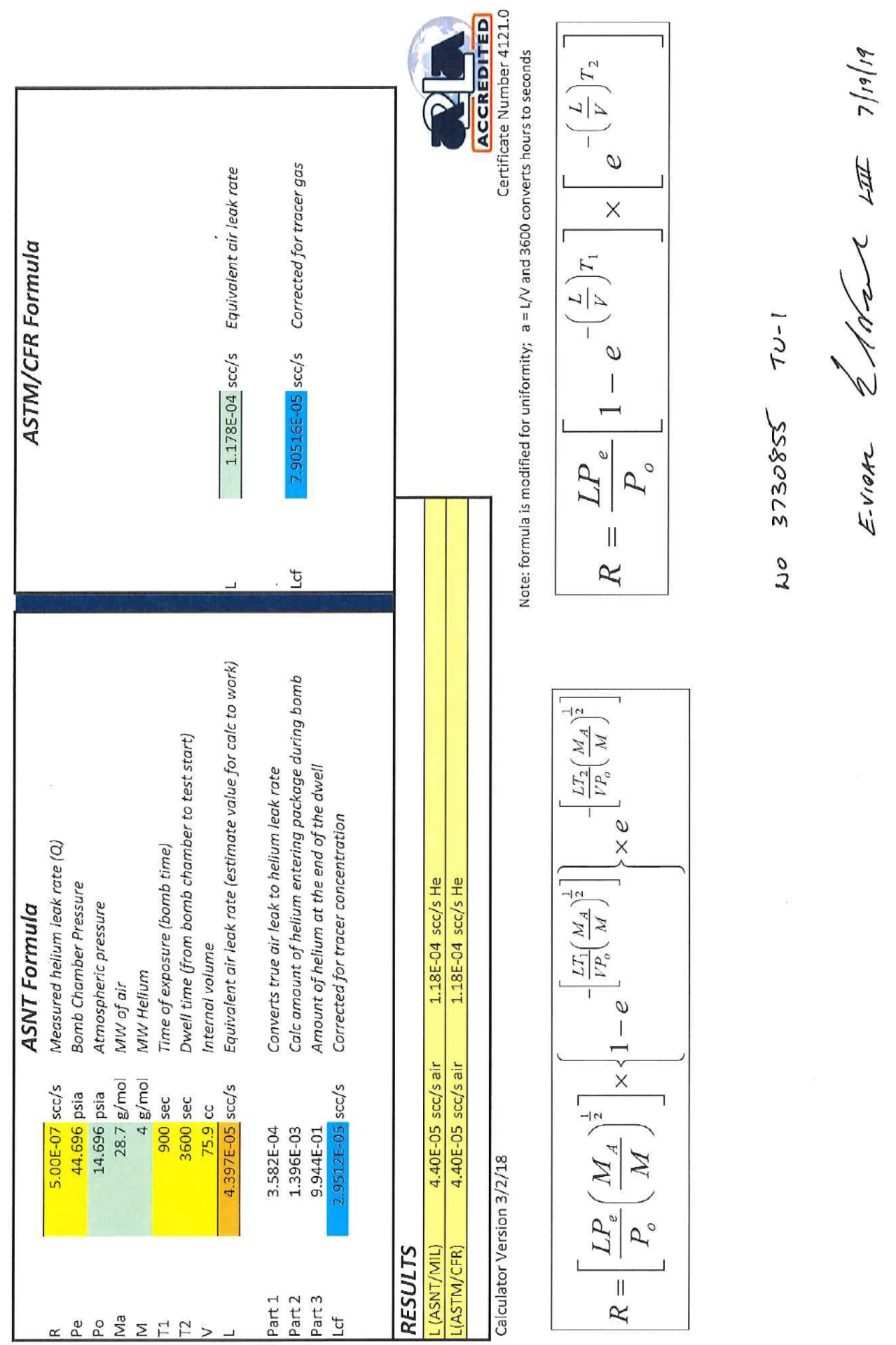




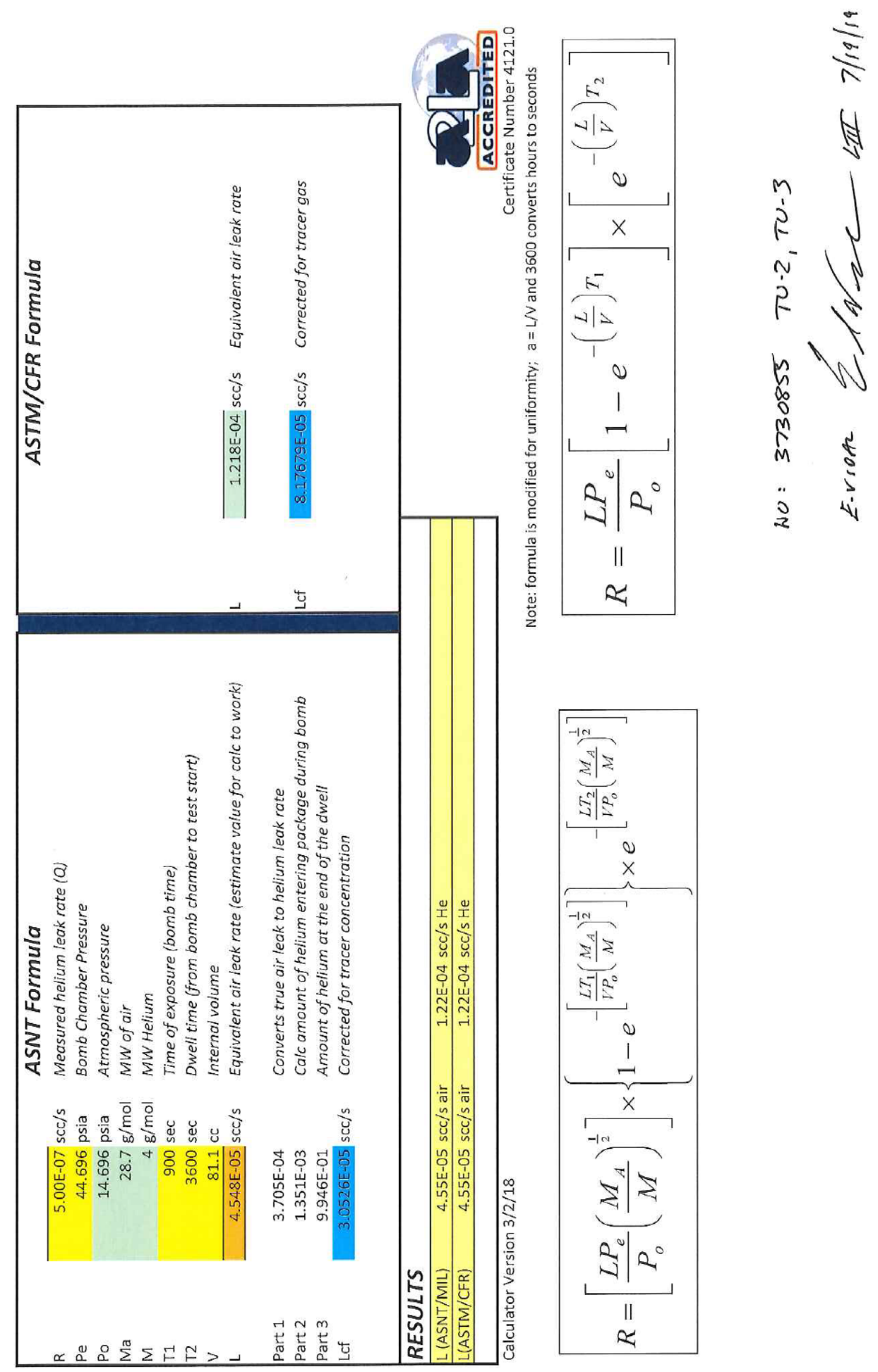




\section{PRESSURE GAGE CALIBRATION DATA SHEET}

\begin{tabular}{|c|c|c|}
\hline DUT M\&TE \# 767 & $\begin{array}{l}\text { Range } \\
0 \cdot 100 \text { psig }\end{array}$ & $\omega k A$ \\
\hline Calibration Frequency & Scale Subdivisions & Accuracy $(\%$ Span $1 / 4-1 / 2-1 / 4)$ \\
\hline AFTER USE & 0.1 ps 19 & Grade B: $3-2-3$ \\
\hline Calibrator Used & & $\begin{array}{l}\text { Calibration Date } \\
\qquad 10-11-17\end{array}$ \\
\hline Calibrator Pressure Module & $1 A$ & Calibration Date 1 \\
\hline Visual Inspection: & ÁAccept & $\square$ Reject \\
\hline
\end{tabular}

\begin{tabular}{|c|c|c|c|c|}
\hline & \multicolumn{2}{|c|}{ DUT } & \multirow{2}{*}{$\begin{array}{c}\text { Standard } \\
\text { Gage }\end{array}$} & \multirow{2}{*}{$\begin{array}{c}\text { Allowed } \\
\text { Error }\end{array}$} \\
\hline & Scale & Reading & & \\
\hline \multirow{5}{*}{ s } & $0 \%$ & 0 & 0 & 3.0 \\
\hline & $25 \%$ & 25 & 24.7 & 2.0 \\
\hline & $50 \%$ & 50 & 49.7 & 2.0 \\
\hline & $75 \%$ & 75 & 75 & 2.0 \\
\hline & $100 \%$ & 100 & 99.5 & 3.0 \\
\hline \multirow{5}{*}{$\begin{array}{l}5 \\
0 \\
0 \\
0\end{array}$} & $100 \%$ & 100 & 100 & 3.0 \\
\hline & $75 \%$ & 75 & 74.7 & 2.0 \\
\hline & $50 \%$ & 50 & 49.7 & 2.0 \\
\hline & $25 \%$ & 25 & 24,7 & 2.0 \\
\hline & $0 \%$ & 0 & 0 & 3.0 \\
\hline
\end{tabular}

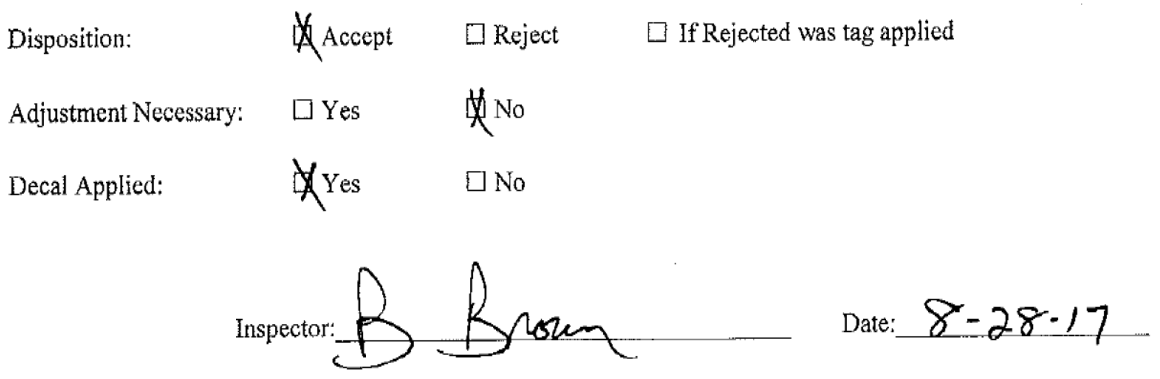




\begin{tabular}{|c|c|c|c|}
\hline (0) RNL & \multirow{3}{*}{$\begin{array}{l}\text { Operating Procedures for HAC } \\
\text { Drop Test - Testing of Radioactive } \\
\text { Material Packages }\end{array}$} & \multicolumn{2}{|c|}{$\begin{array}{l}\text { Test Procedure } \\
\text { P'TP-PRF-10 }\end{array}$} \\
\hline $\begin{array}{l}\text { PACKAGE TESTING PROGRAM } \\
\text { OAK RIDGE NATIONAL LABORATORY } \\
\text { OAK RIDGE, TENNESGEC } 37831\end{array}$ & & Page: $1 / 7$ & $\begin{array}{r}\text { tssue Denek } \\
2-1-19\end{array}$ \\
\hline 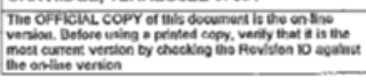 & & $\begin{aligned} \text { Revision Datr: } \\
1-31-19\end{aligned}$ & $\begin{array}{r}\text { Reviow By Done } \\
1-31-22\end{array}$ \\
\hline $\begin{array}{l}\text { Wition By: } \\
\text { Richard Michelhaugh }\end{array}$ & Matt Feldman & Scaglion & \\
\hline
\end{tabular}

1. Scope

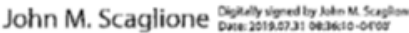

This procedure describes the process that the Package Testing Program (PTP) uses in the performance of Hypothetical Accident Conditions (HAC) drop tests, using a release mechanism, rigging, and a crane/hoist. Drop tests are performed during the package testing sequence to demonstrate compliance with the performance requirements embodied within the radioactive materials packaging requirements.

\section{Safety Precautions}

It is the responsibility of PTP personnel to remain alert to potential hazards and take the necessary precautions to ensure a safe working environment. Personnel Protective Equipment required for conducting drop tests: safety glasses w/side shields, hardhat, gloves and safety shoes. Observers of drop tests are required to wear safety glasses w/side shields and hard hats. All persons (workers and observers) should be familiax with the hazards associated with drop tests, which involve the release (drop) of heavy objects from specified heights, as well as manipulating heavy objects in preparation for such tests. All persons shall remain sufficiently clear of test specimens during any lifting operation to eliminate the possibility of injury from an accidental release. Release mechanisms are used to initiate the controlled release of the test specimen. Release mechanisms shall not be used for general hoisting operations - a release mechanism shall only be used to lift the test specimen in preparation for the actual drop test. Other test specimen lifts shall be accomplished with proper and approved rigging attached to the crane hook. Release mechanisms shall remain disconnected from actuating power sources until the test specimen is in final position and ready to be released.

\section{Equipment}

- Release Mechanisms:

PTP Small Release Mechanism, IE 11631, (for test specimens with a gross mass less than 3000-lb). This is an electro-mechanical device in which an electrically actuated solenoid is used to open the release mechanism jaws, resulting in single-point release of the object suspended from the crane. 


\begin{tabular}{|c|c|c|c|c|}
\hline (0)圆政 & \multirow{3}{*}{$\begin{array}{l}\text { Operating Procedures for HAC } \\
\text { Drop Test - Testing of Radioactive } \\
\text { Material Packages }\end{array}$} & \multicolumn{2}{|c|}{$\begin{array}{l}\text { Test Procodure: } \\
\text { PTP-PRF-10 }\end{array}$} & Rav. 6 \\
\hline $\begin{array}{l}\text { PACKAGE IESIING PROGRAM } \\
\text { ONK RIDGE NATIONAL LAOORATORY } \\
\text { OAK RIDGE, TENNESSEE 37831 }\end{array}$ & & Page. $2 / 7$ & |lossue De & $-1-19$ \\
\hline 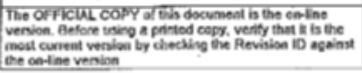 & & $\begin{array}{r}\text { Revision Date: } \\
1-31-19\end{array}$ & $\begin{array}{r}\text { Review: } \\
1-\end{array}$ & $\begin{array}{l}\text { By Date: } \\
31-22\end{array}$ \\
\hline
\end{tabular}

OR

PTP "Big Red" Release Mechanism, IE 12437, (for test specimens with a gross mass up to 20,000-lb). This is a larger version of the PTP Small Release Mechanism, enabling a drop capacity up to 20,000-lb. For these larger packages, it will be necessary to use the outside drop pad, a mobile crane, release mechanism, and appropriate rigging to conduct this drop test.

OR

Explosive Cable Cutters and Bolts. For some drop tests (especially those that exceed the capacity of the available release mechanisms, the use of alternative releasing methods (such as explosive cable cutters or explosive nut/bolts) is required. For these devices, an explosive charge is used to cause the release of the test specimen.

- Drop Pad:

The drop pad that may be used for this test are documented in Design and Certification of Targets for Drop Testing at the NTRC Package Research Facility Rev. 0, May 2003, ORNL/NTRC-001. The document addresses dimensions, surface description, construction details, and the suitability of each drop pad as a flat, essentially unyielding surface for impact (target) pads. The outside drop pad has a steel impact surface and mass in excess of 140 tons.

NTRC Large Drop Pad. This drop pad is located adjacent to the NTRC PEF, and is embedded in the parking lot outside NTRC Room L110. The Large Drop Pad is certified as "essentially unyielding" for 9-m (30-ft) drops of test specimens weighing up to approximately $28,000-1 \mathrm{~b}$.

- Plumb bob cable. A commercial measuring tape or other suitable measuring device is to be used to verify the length of the plumb bob cable.

- Digital Camera, Video Camera and Photographer's Clapboard.

- Rigging suitable for lifting the package as required. Rigging includes items such as straps, wire rope chokers, shackles, etc. 


\begin{tabular}{|c|c|c|c|c|}
\hline (O) R̂N & \multirow{3}{*}{$\begin{array}{l}\text { Operating Procedures for HAC } \\
\text { Drop Test - Testing of Radioactive } \\
\text { Material Packages }\end{array}$} & \multicolumn{2}{|c|}{$\begin{array}{l}\text { Tent Procodure } \\
\text { P'TP-PR F-10 }\end{array}$} & ${ }^{R e v .} 6$ \\
\hline $\begin{array}{l}\text { PACKAGE TESTING PROGRAM } \\
\text { OAK RRDGE NATONAL LARORATORY } \\
\text { OAK RIDGE, IENNESSEE } 37831\end{array}$ & & Page: $3 / 7$ & Issue & $1-19$ \\
\hline 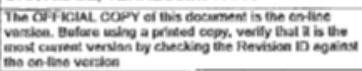 & & $\begin{array}{r}\text { Revision Date } \\
1-31-19\end{array}$ & & $\begin{array}{l}\text { Dy Doner } \\
31-22\end{array}$ \\
\hline
\end{tabular}

- A thermometer for measuring the ambient temperature. Any commercial thermometer may be used, and calibration is not required. The PTP Fluke Thermocouple Thermometer is sufficient for this purpose.

- Test Specimen(s) (i.e., packaging test units)

\section{Test Procedure}

4.1. Ensure that Measuring \& Test Equipment (M\&TE) meets the requirements of PTP-QA-013, "Procedure on Control of Measuring and Test Equipment'. Record any M\&TE on the Procedure Data Sheet.

4.2. Initiate a unique Procedure Checklist form and Data Sheet form for each Test Specimen. Record the Test Plan identifier and Test Unit identifier on each form. Record completion of each step and other required information at appropriate locations on Procedure Checklist and Data Sheet, as referenced by the following procedure steps.

4.3. The drop orientation is specified in the specific Test Plan for each package. Record the orientation.

4.4. Prepare photographer's clapboard with package name and test specimen identification information.

4.5. Rig the test specimen in the required orientation using the selected release mechanism and measure and record the attitude. The tolerance for rigging the angle of a test specimen's attitude is $+/-2.0^{\circ}$ unless otherwise specified in the Test Plan. As a general rule, the testing team will rig the package to a tolerance of $+/-1.0^{\circ}$, if possible, given the attachment points and rigging available for a particular package. Take photograph of rigged and raised specimen. Take photograph of angle measurement.

4.6. Attach the PT'P plumb bob cable to the lowest point of the test specimen with tape. The package will be properly blocked while attaching the cable to keep the operator safe in the event that the package is released prematurely. 


\begin{tabular}{|c|c|c|c|c|}
\hline (O) RNL & \multirow{3}{*}{$\begin{array}{l}\text { Operating Procedures for HAC } \\
\text { Drop Test - Testing of Radioactive } \\
\text { Material Packages }\end{array}$} & \multicolumn{2}{|c|}{$\begin{array}{l}\text { Test Procoduce: } \\
\text { PTP-PRF-10 }\end{array}$} & ${ }_{6}^{\operatorname{Rev} .}$ \\
\hline $\begin{array}{l}\text { PACKAGE TESTING PROGRAM } \\
\text { OAK RIDGE NATONAL LAORATORY } \\
\text { OAK RIDGE, TENNESSEE } 37831\end{array}$ & & $4 / 7$ & $\begin{array}{r}\text { howe } \\
2\end{array}$ & $-1-19$ \\
\hline 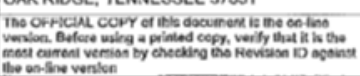 & & $\begin{array}{r}\text { Revision Date. } \\
1-31-19\end{array}$ & & $\begin{array}{l}\text { By Dale: } \\
31-22\end{array}$ \\
\hline
\end{tabular}

4.7. Raise the test specimen to the specified drop height. Take photograph of height measurement. Pull the cable removal string and remove the 9$\mathrm{m}$ plumb bob and cable from the drop pad.

4.8. Confirm that video cameras are rolling. Plug release mechanism into power. Countdown. Trigger release mechanism. Disconnect power from release mechanism.

4.9. Stop video cameras.

4.10. Record Date and time of test and record the ambient temperature at the test time.

4.11. Photograph damaged test specimen as it lies from drop. Turn test specimen to reveal any damage and photograph the damage. When inspection is complete, move the test unit from the drop pad.

4.12. The Test Engineer shall sign and date the completed Procedure Checklist and Data Sheet. A Quality Representative shall check each of these test forms for accuracy and completeness and sign and date each checked test form 


\begin{tabular}{|c|c|c|c|c|}
\hline (O)㡶NL & \multirow{3}{*}{$\begin{array}{l}\text { Operating Procedures for HAC } \\
\text { Drop Test - Testing of Radioactive } \\
\text { Material Packages }\end{array}$} & \multicolumn{2}{|c|}{ P'TP-PRF-10 } & Rov. 6 \\
\hline $\begin{array}{l}\text { PACKAGE TESTING PROGRAM } \\
\text { OAK RIDGE NATIONAL LABORATORY } \\
\text { OAK RIDGE, TENNESSEE } 37831\end{array}$ & & $5 / 7$ & lssua & $1-19$ \\
\hline 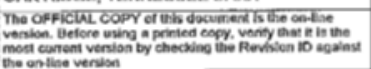 & & $\begin{array}{r}\text { Revision Date: } \\
1-31-19\end{array}$ & & $\begin{array}{l}3 \text { Date } \\
31-22\end{array}$ \\
\hline
\end{tabular}

\section{Review and Revision History}

- 1-30-04 - Original Issue

- 5-27-04 - Expanded step 4.7 to explicitly require removal of the plumb bob before proceeding to next step. Added verification step to checklist.

- 12-01-06 - Triennial Review. Editorial changes. Modified Signoff responsibilities for Checklist and Data Sheet.

- 1-31-10 - Reviewed, no changes made

- 1-31-13 - Reviewed, added ambient temperature recording to the end of the checklist. Also added attitude description in Section 7.

- 1-19-16 - Triennial review, removed TTG reference. Approved by changed to current UFS group leader. - Oscar Martincz

- 1-20-19 - Triennial review. Checked by must be performed by a QR if applicable. Included a step to ensure all equipment has been calibrated per the PTP-QA-013 procedure. Oscar Martinez 


\begin{tabular}{|c|c|c|c|c|}
\hline (0) $R \mathbb{N} L$ & \multirow{3}{*}{$\begin{array}{l}\text { Operating Procedures for HAC } \\
\text { Drop Test - Testing of Radioactive } \\
\text { Material Packages }\end{array}$} & \multicolumn{2}{|c|}{$\begin{array}{l}\text { Test Proctodure } \\
\text { PTP-PRF-10 }\end{array}$} & 6 \\
\hline $\begin{array}{l}\text { PACKAGE TESTING PROGRAM } \\
\text { OAK RDOGE NATIONUL LABOPATORY } \\
\text { OAK RIOGE, IENENESSEE 3/831 }\end{array}$ & & Page $7 / 7$ & Tlssue Di & $1-19$ \\
\hline 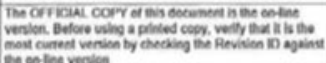 & & $\begin{array}{l}\text { Revision Date. } \\
1-31-19\end{array}$ & Revient: & \\
\hline
\end{tabular}

\section{Data Sheet}

\begin{tabular}{l} 
Test Plan: \\
ORNH/NTRC. O84 \\
\hline
\end{tabular}

\section{Test Unit:}

$$
1
$$

VERIFIEI

TASK
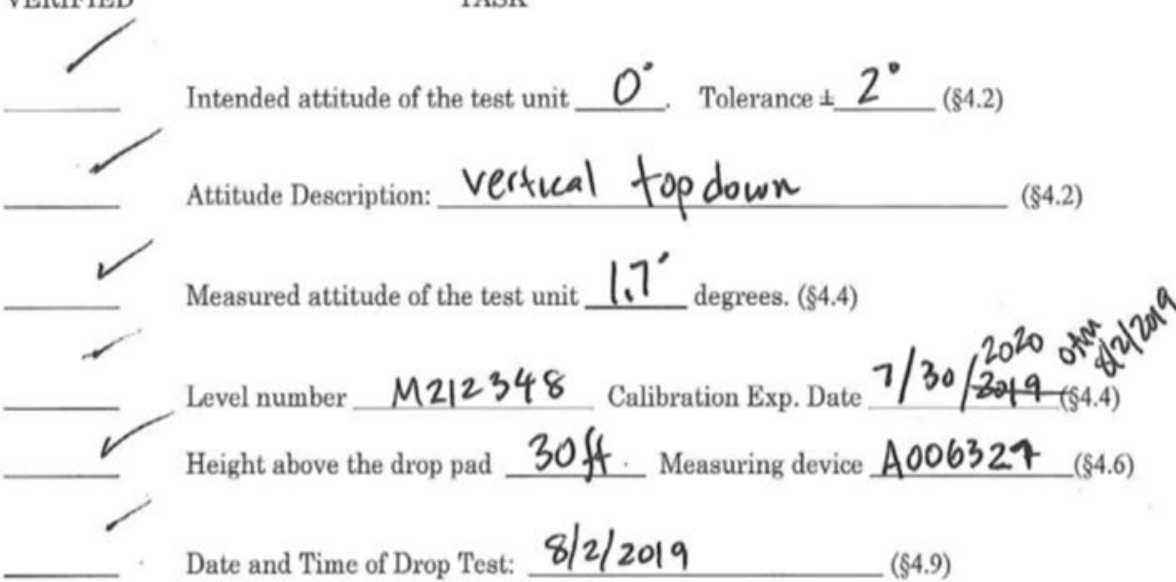

N|A

Ambient temperature: ${ }^{\circ} \mathrm{C}$ ( $\left.{ }^{\circ} \mathrm{F}\right)$

Measuring device $(\$ 4.9)$

\section{Testing Damage Observations:}

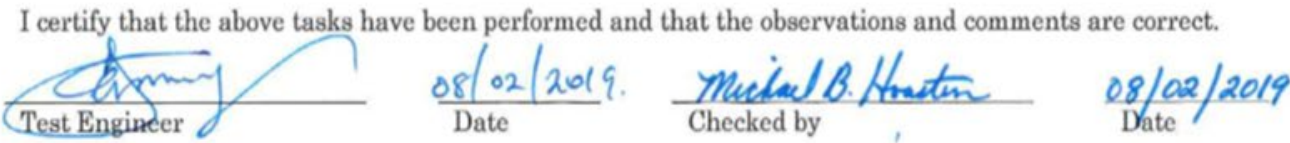




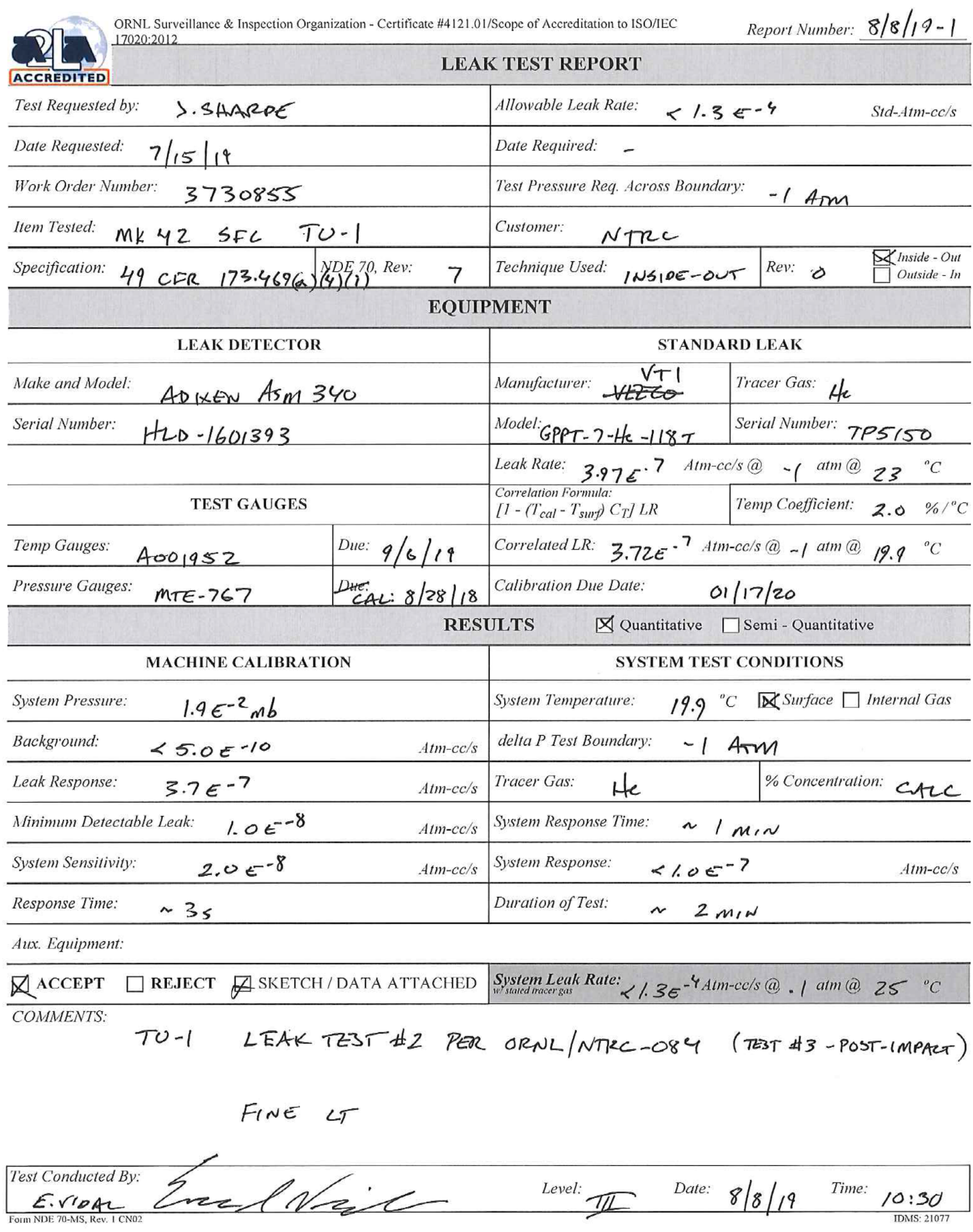


ORNL Surveillance and Inspection Organization / Certification Number: $412 \mathrm{~L} 01 /$ Scone of Accreditation to ISO/IEC 17020:201

\begin{tabular}{|c|c|c|c|}
\hline BOMBING TEST REPORT (Supplement) & & & ACCREDITED \\
\hline Leak Test Report Number: $\quad 8 / 8 / 19-1$ & Allowable Leak Rate: & $<1.3 \mathrm{E}^{-4}$ Arm $\mathrm{ca} / \mathrm{s}$ & \\
\hline
\end{tabular}

Item(s) Tested:

$M K-42$ SFC TU-1

TRACER GAS BOMBING AND LEAK TEST

\begin{tabular}{|c|c|c|c|c|}
\hline Bombing Pressure (psig) & 30 & Tracer Gas: & He & Bombing Time: $15 \mathrm{~m}, \mathrm{~d}$ \\
\hline Waiting Time (Sec): & $<3600$ & & Internal Volume (cc): & 75.9 \\
\hline Measured Leak Rate: & $<5.0 \epsilon^{-7}$ & Atm cc/s & Calculated Leak Rate: & $<1.3 \varepsilon^{-4}$ Atm cc/s into vac. (a) $25{ }^{\circ} \mathrm{C}$ \\
\hline
\end{tabular}

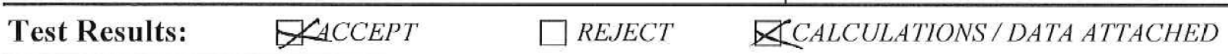

COMMENTS:

Test Conducted By:

Form NDE 70-Bomb Rev.1 CN02

IDMS: 21078 


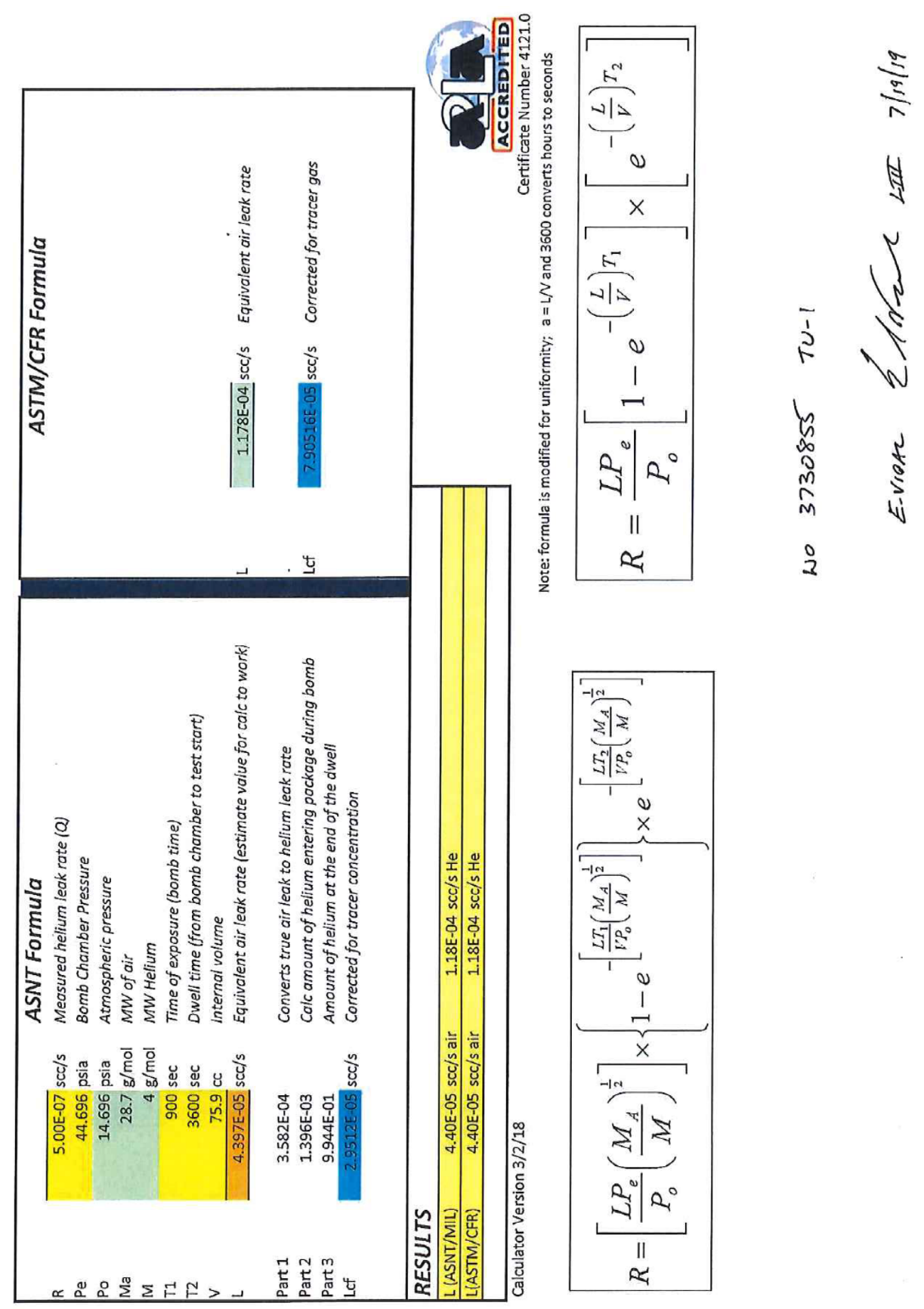


PRESSURE GAGE CALIBRATION DATA SHEET

\begin{tabular}{|c|c|c|}
\hline DUT METE \# 767 & $\begin{array}{l}\text { Range } \\
0-100 \mathrm{psig}\end{array}$ & Manufacturer wiKA \\
\hline Calibration Frequency & Scale Subdivisions & Accuracy (\%Span $1 / 1 / 1 / 2-1 / 4)$ \\
\hline AFTER USE & $0.1 \quad \rho s / g$ & Grade B: $3-2-3$ \\
\hline \multicolumn{2}{|c|}{ Calibrator Used } & Calibration Date $10.11-17$ \\
\hline \multicolumn{2}{|c|}{ Calibrator Pressure Module } & Calibration Date $1 / A$ \\
\hline
\end{tabular}

Visual Inspection:

\begin{tabular}{|c|c|c|c|c|}
\hline & \multicolumn{2}{|c|}{ DUT } & \multirow{2}{*}{$\begin{array}{c}\text { Standard } \\
\text { Gage }\end{array}$} & \multirow{2}{*}{$\begin{array}{c}\text { Allowed } \\
\text { Error } \\
\end{array}$} \\
\hline & Scale & Reading & & \\
\hline \multirow{5}{*}{ 号 } & $0 \%$ & 0 & 0 & 3.0 \\
\hline & $25 \%$ & 25 & 24,7 & 2.0 \\
\hline & $50 \%$ & 50 & 49.7 & 2.0 \\
\hline & $75 \%$ & 25 & 75 & 2.0 \\
\hline & $100 \%$ & 100 & 99.5 & 3.0 \\
\hline \multirow{5}{*}{ 官 } & $100 \%$ & 100 & 100 & 3.0 \\
\hline & $75 \%$ & 75 & 74.7 & 2,0 \\
\hline & $50 \%$ & 50 & 49.7 & 2.0 \\
\hline & $25 \%$ & 25 & 24.7 & 2.0 \\
\hline & $0 \%$ & 0 & 0 & 3.0 \\
\hline
\end{tabular}

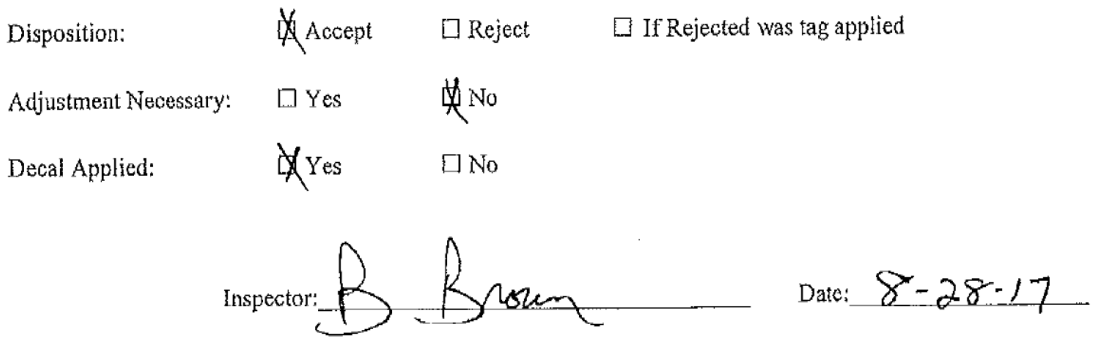

FORM NDE-80-2 Rev. 1

IDMS: 6438 


\begin{tabular}{|c|c|c|}
\hline Test Requested by: >.SHARPE & \multicolumn{2}{|l|}{ RNSD } \\
\hline Date Requested: $\quad 7 / 15 / 19$ & \multicolumn{2}{|l|}{ Date Required: _ } \\
\hline Work Order Number: $\quad 3730855$ & NDE 70, Rev: 7 & Tech, NDE 70-BT Rev: 0 \\
\hline Item Tested: MK.42 SFC TU-1 & Test Pressure Required: & $15^{\prime \prime}+1 y$ \\
\hline Specification: 49 cFe $173.469(a)(4)(i)$ & Inspection Criteria: No & PNDICATIONS $\varrho 2$ MIN \\
\hline Technique Used: VAC BuX & Liquid Media Used: & UMERSIT cim 200 e $20 \%$ sou \\
\hline Test Gas Used: & Liquid Applicator Type: & IMMERSION \\
\hline Inspection Light Intensity: $\quad>100 \mathrm{Fc}$ & Post Cleaning Method: & DI RINSE/WIPE DRY \\
\hline Other Apparatus Used: & & \\
\hline
\end{tabular}

\section{Direct Pressure Technique $\square \quad$ Vacuum Pressure Technique $\not \subset$}

Component Limits of Test:

TEST SEQUENLE \#3, LEAK TEST I2 -PUST-IMPAUT

PER ORNL/NTRC-O8Y

\begin{tabular}{|c|c|c|c|c|c|c|c|}
\hline \multicolumn{2}{|c|}{5500} & \multicolumn{3}{l|}{ Component Installation Site - } \\
\hline \hline \multicolumn{3}{|c|}{ Gauges } & \multicolumn{2}{c|}{ Test Pressure } & \multicolumn{2}{c|}{ Temperature } \\
\hline Mfg & $10 \mathrm{No}$ & $\begin{array}{c}\text { Calibration } \\
\text { Date }\end{array}$ & Range & Beginning & End & Beginning & End \\
\hline & A002124 & $10 / 14 / 18$ & $0-30^{\prime \prime} \mathrm{Hg}$ & $15^{\mathrm{r}} \mathrm{Hg}$ & $23^{\prime \prime} \mathrm{Hg}$ & $19.9^{\circ} \mathrm{C}$ & $19.9^{\circ} \mathrm{C}$ \\
\hline
\end{tabular}

Temperature Measuring Device

\begin{tabular}{|c|c|c|c|c|c|}
\hline Mfg. OMEGA & Model & $\mathrm{HH} 1804$ & Range & K-TYPE & I.D. Number Aool952 \\
\hline RESULTS & $\varnothing \mathrm{ACCEPT}$ & $\square$ REIECT & & \multicolumn{2}{|c|}{ POST CLENING PERFORMED: ØY $\square N$} \\
\hline \multicolumn{6}{|l|}{ Comments: } \\
\hline \multicolumn{6}{|c|}{ Geoss $\angle T$} \\
\hline \multicolumn{6}{|l|}{ Test Conducted By: } \\
\hline E.VIOAL & & & & Level: TII & Insp. Date: $8 / 8 / 19$ \\
\hline
\end{tabular}




\section{TEST FORM 1 - Percussion Test Form}

Test Plan

ORNL/NTRC-084 Rev 0

Test Unit TU- I

VERIFIED

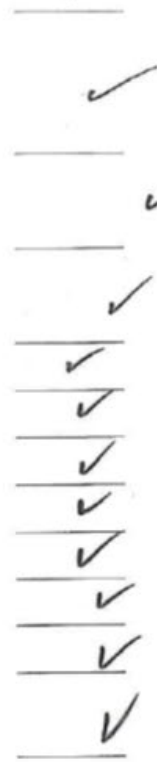

TASK

The weight of the percussion billet has been measured and verified to be $3 \mathrm{lbs}$ or greater:

Measured weight of billet $\quad 1.4249$

Scale used for measurement: $\mathrm{AogO} \mathrm{SO}_{3}$

(lbs.)

The calibration of the 1-m ruler has been verified:

I-m Ruler Equipment \#__ A000853

The dimensions of the lead sheet have been measured by commercial tape measure:

Thickness $I^{\prime \prime} \quad$ Length $12^{\prime \prime}$ Depth

Depth

7/25/2020

The lead sheet has been placed on the unyielding surface and a picture has been taken.

The test unit has been placed (centered) on the lead shect and a picture has been taken.

The drop test release mechanism has been attached to the crane.

The percussion billet has been captured by the release mechanism.

The billet has been centered over the test unit and a picture has been taken.

The billet has been raised to height of 1 meter over the highest point of the test unit and a picture has been taken.

The billet was released and impacted the test unit.

All observable damage to the test unit caused by the percussion test has been recorded and pictures of the test unit after the percussion test have been taken.

Form has been signed and dated by the Quality Assurance Representative (QAR).

Comments:

I certify that the above tasks have been performed and that the observations and comments are correct.

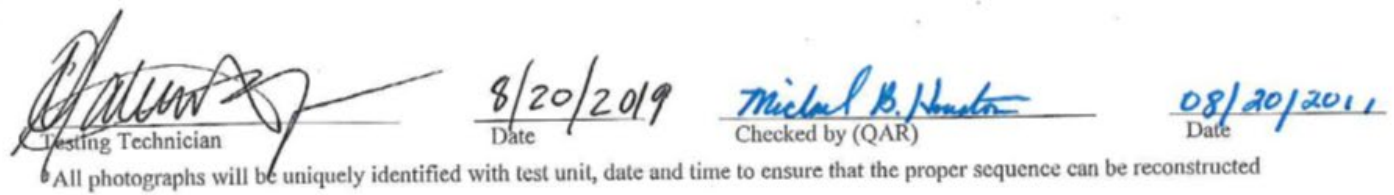

All photographs will be uniquely identified with test unit, date and time to ensure that the proper sequence can be reconstructed 
LEAK TEST REPORT

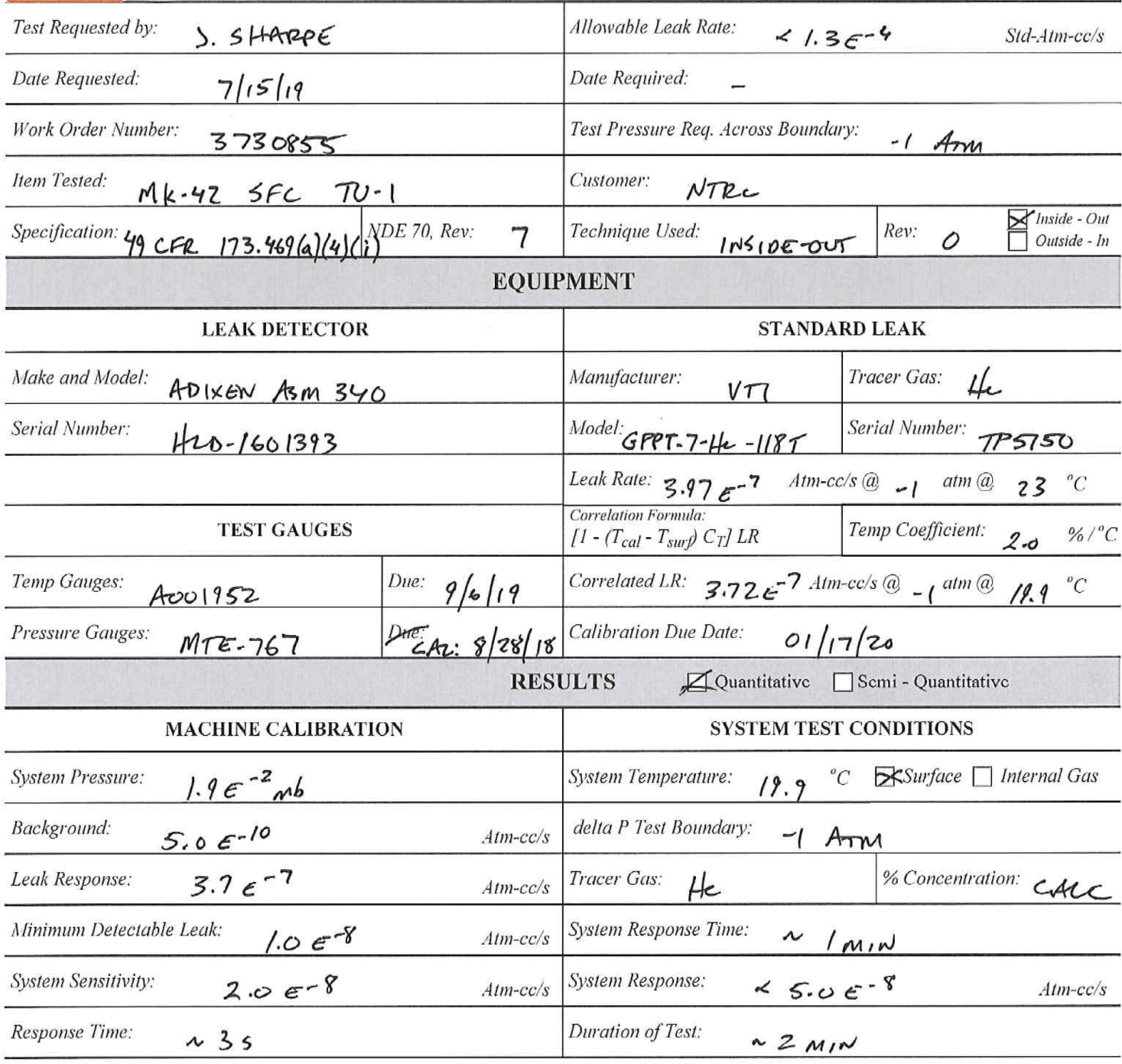

Aux: Equipment:

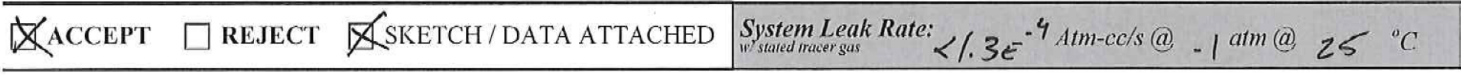
COMMENTS:

TU-1 LEAK TEST \#3 RER ORNL/NTRC-O84 (TEDT\#S PUST.PERCUSSION) FINE $L$ T

E.VioAz


ORNL Surveillance and Inspection Organization / Certification Number: 4121.01/Scope of Accreditation to LSO/LC 17020:2012

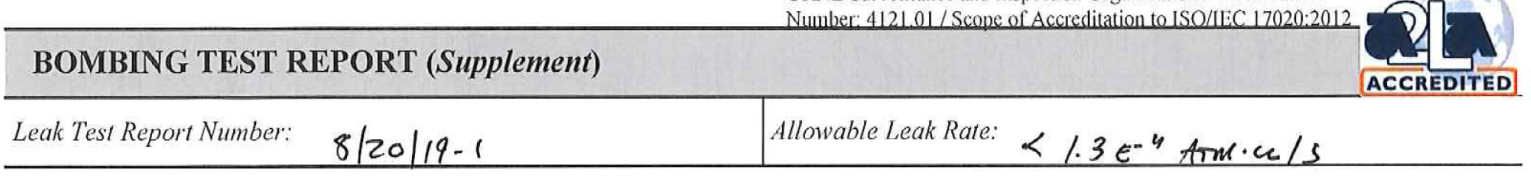

Item(s) Tested:

$$
\text { MK-42 SFC TU.1 POSF-PERcussion }
$$

\begin{tabular}{|c|c|c|c|c|}
\hline \multicolumn{5}{|c|}{ TRACER GAS BOMBING AND LEAK TEST } \\
\hline Bombing Pressure (psig). & 30 & Tracer Gas: & He & Bombing Time: \\
\hline Waiting Time (Sec): & $<3600$ & & Internal Volume (cc): & 75.9 \\
\hline Measured Leak Rate; & $<5.0 t^{-7}$ & Atm cc/s & Calculated Leak Rate: & $<1.3 t^{-4}$ Atm cols into vac. (Q) 2) $-{ }^{\circ} \mathrm{C}$ \\
\hline
\end{tabular}

\begin{tabular}{l} 
Test Results: \ACCEPT $\square$ REJECT \CALCULATIONS / DATA ATTACHED \\
\hline COMMENTS:
\end{tabular}

\section{Test Conducted By:}

E-VIPA

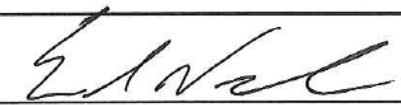

Level:

III

IDMS: 21078 

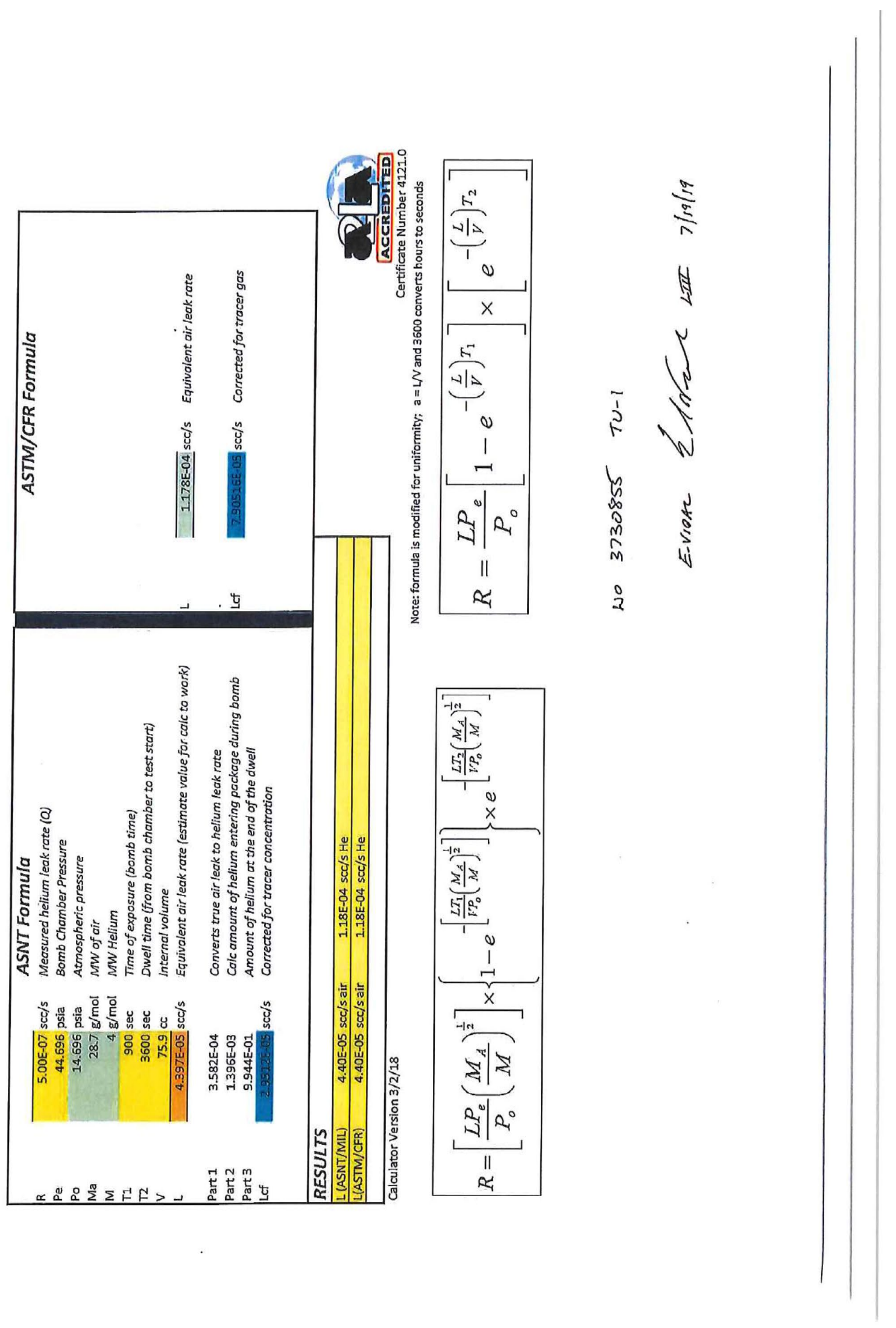


\section{LEAK TEST REPORT - BUBBLE TEST}

Test Requested by:

S. Sharde

Date Requested: $\quad 7 / 15 / 19$

Work Order Number:

3730855

Item Tested:

$M K-42$ SFC TU.1

Specification: 49 CFR $173.469(a)(4)(i)$

Technique Used:

VAC BOX

Test Gas Used: $\quad \mathrm{VAz}$

Inspection Light Intensity:

$>100 \mathrm{Fe}$ Customer: NTRC Date Required: NDE 70, Rev: 7 Tech, NDE 70-BT Rev: Test Pressure Required: $15^{\prime \prime} \mathrm{Hy}$ Inspection Criteria: No INDICAD OWS $2 \mathrm{MrN}$ Liquid Media Used: IMmensit um 200 e $20 \%$ som Liquid Applicator Type: IMmeresior

Other Apparatus Used:

FLASHCIOHT

\section{Direct Pressure Technique $\quad \square \quad$ Vacuum Pressure Technique $\square$}

Component Limits of Test:

TEST SERUTNCE $\$ S, \angle T \# 3$ - POST-PERCUSSIOW TEST PER ORNL/NTRC-084

\begin{tabular}{|c|c|c|c|c|c|c|c|}
\hline \multicolumn{2}{|c|}{ Component Test Site } & \multicolumn{2}{|c|}{5500} & \multicolumn{4}{|c|}{ Component Installation Site } \\
\hline \multicolumn{4}{|c|}{ Gauges } & \multicolumn{2}{|c|}{ Test Pressure } & \multicolumn{2}{|c|}{ Temperature } \\
\hline \multirow[t]{2}{*}{ Mfg } & ID No & $\begin{array}{c}\text { Calibration } \\
\text { Date }\end{array}$ & Range & Beginning & End & Beginning & End \\
\hline & A002124 & $10 / 14 / 18$ & 0.30119 & $-18^{\prime} \mathrm{Hg}$ & $-18^{\prime \prime} \mathrm{Hy}$ & $19.9^{\circ} \mathrm{C}$ & $19.9^{\circ} \mathrm{C}$ \\
\hline
\end{tabular}

Temperature Measuring Device

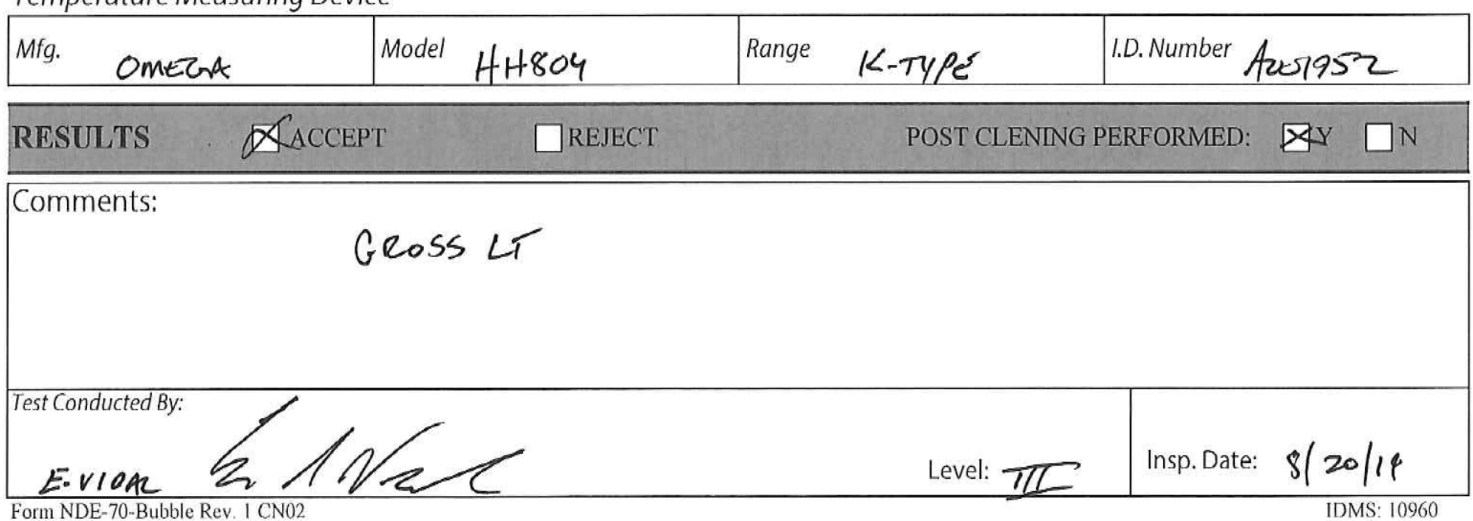




\section{TEST FORM 2 - Heat Test Checklist}

Test Plan ORNL/NTRC-084

Rev. 0

Test Unit 2
VERIFIED
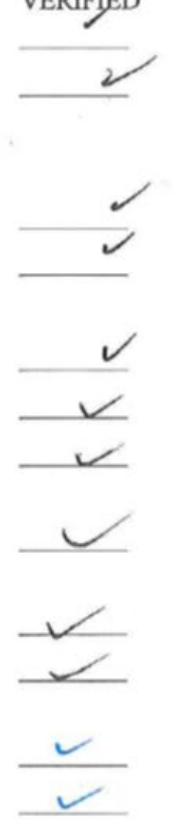

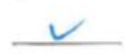

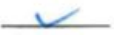

TASK

The test unit tray has been placed in the furnace.

Two calibrated Type K thermocouples have been installed in the working area of the furnace and attached to the Fluke thermocouple reader.

Thermocouple calibration date: $11-12-18$

Delta M. Coip TypeK

The furnace doors have been closed and the furnace has been turned on with a set point of $850^{\circ} \mathrm{C}$.

Thermocouple readings have been made every 60 minutes for at least 3 hours with a calibrated thermocouple reader Thermocouple reader model number $M 303131$ Calibration date: $11-12-18 \rightarrow 11-12-19$

Any changes in the furnace set point during the three-hour preheat period have been recorded on TEST FORM 3.

Just prior to test unit insertion, a final preheat temperature recording was made.

Prior to opening the furnace ensure the operator has the proper PPE including gloves rated for work in 850 deg C atmosphere and a similarly rated face shield if required.

The furnace door has been opened, the test unit inserted, the furnace door closed, and the furnace activated with a set point of $850^{\circ} \mathrm{C}\left(1560^{\circ} \mathrm{F}\right)$ (or as adjusted during the preheat process).

When both thermocouple readings have reached $800^{\circ} \mathrm{C}\left(1475^{\circ} \mathrm{F}\right)$, the 10-minute thermal test was started.

Thermocouple readings were taken and recorded on TEST FORM 4 every 30 seconds for the duration of the 10-minute thermal test.

Adjustments were made to the furnace set point as directed by the test director.

When the 10-minute test period was finished, the furnace was turned off and furnace door was opened to the maximum extent possible.

As soon as conditions permitted, the test unit was removed from the furnace and allowed to cool naturally.

Any deformation or other unusual circumstances regarding the test or the test unit was recorded.

Form has been signed and dated by the Quality Assurance Representative (QAR).

Comments: Pictures wore taken, no daforination obserued.
Furnace was allowed to hact-lacku up after Tu-2 remaval,

I certify that the above tasks have been performed and that the observations and comments are correct.

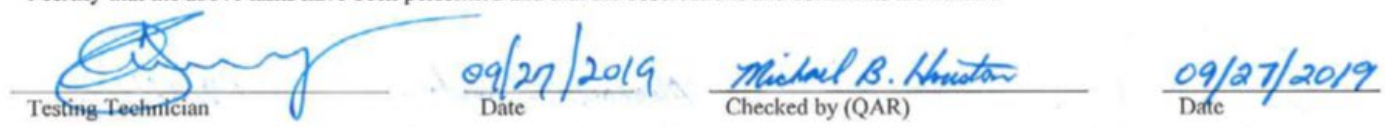

*All photographs will be uniquely identified with test unit, date and time to ensure that the proper sequence can be reconstructed

ORNL/NTRC-084, Rev. 0 Apr-19 
TEST FORM 3 - Heat Test Preheat Data Sheet

$\therefore$

VERIFIED

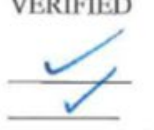

Test Plan ORNL/NTRC-084 Rev. 0

Test Unit 2

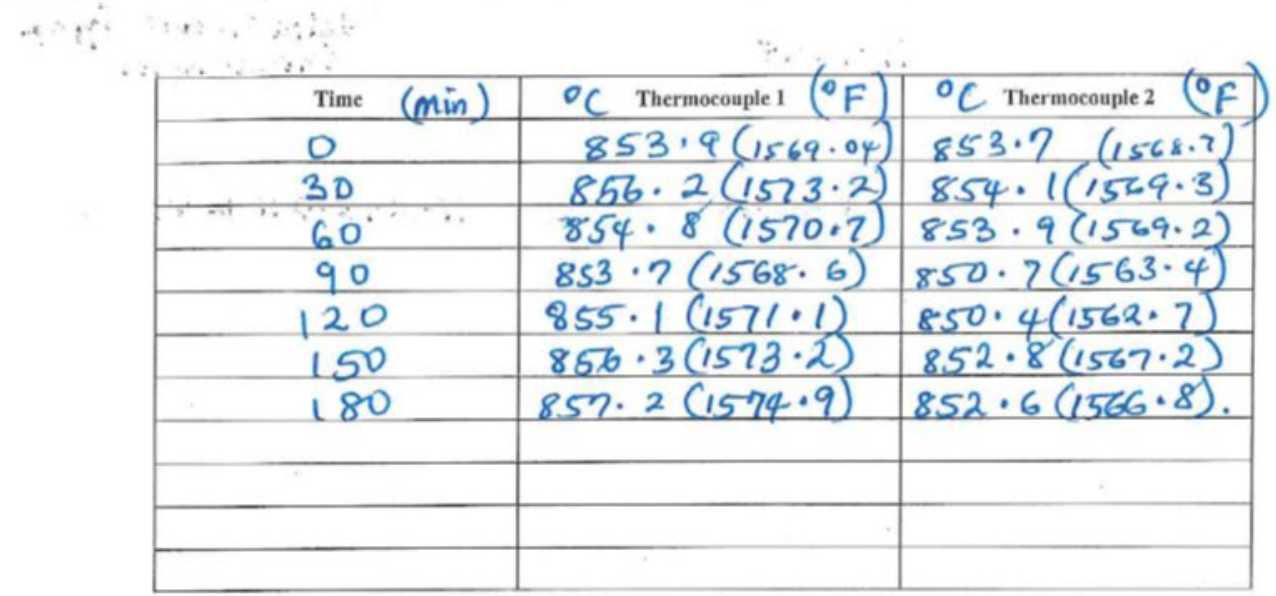

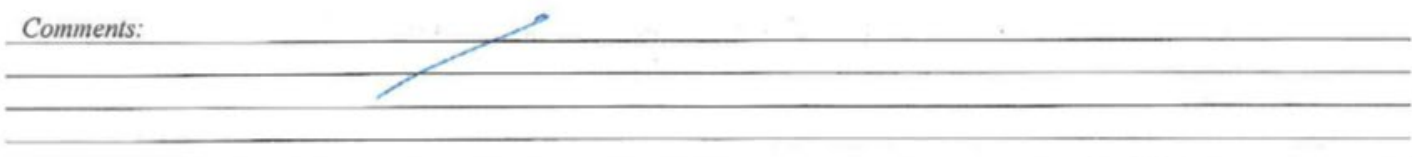

I certify that the above tasks have been performed and that the observations and comments are correct.

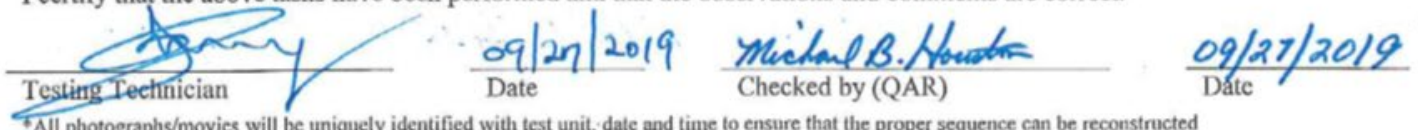

"All photographs/movies will be uniquely identified with test unit, date and time to ensure that the proper sequence can be reconstructed

ORNLNTRC-084, Rev. 0 Apr-19 
TEST FORM 4 - Heat Test Data Sheet

TASK

VERIFIED

Record the temperature in the furnace every 30 seconds for the duration of the test:

Form has been signed and dated by the Quality Assurance Representative (QAR).
Test Plan ORNL/NTRC-084.

Rev. 0

Test Unit 2.

\begin{tabular}{|c|c|c|}
\hline Time (min:sec) & Thermocouple 1 (Celsius) & Thermocouple 2 (Celsius) \\
\hline 00:00 & 822.2 & $831 \cdot 8$ \\
\hline $00: 30$ & 820.9 & 833.9 \\
\hline 01:00 & 825.4 & 833.7 \\
\hline $01: 30$ & 825.8 & 836.2 \\
\hline 02:00 & 824.2 & $841 \cdot 7$ \\
\hline $02: 30$ & 826.4 & 837.9 \\
\hline 03:00 & 826.2 & 844.5 \\
\hline $03: 30$ & 829.9 & $843 \cdot 3$ \\
\hline 04:00 & 833.6 & 843.2 \\
\hline $04: 30$ & $833-4$ & $841 \cdot 8$ \\
\hline $05: 00$ & $-832+3$ & $844 \cdot 4$ \\
\hline $05: 30$ & 831.9 & $848 \cdot 6$ \\
\hline $06: 00$ & 832.3 & 845.1 \\
\hline $06: 30$ & 835.6 & $848 \cdot 9$ \\
\hline 07:00 & 832.3 & $847 \cdot 2$ \\
\hline $07: 30$ & 834.3 & 850.0 \\
\hline 08:00 & 832.9 & 849.9 \\
\hline $08: 30$ & 832.9 & 852.9 \\
\hline 09:00 & 840.4 & $850 \cdot 6$ \\
\hline $09: 30$ & 835.1 & 850.3 \\
\hline $10: 00$ & $829 \cdot 1$ & 849.8 \\
\hline
\end{tabular}

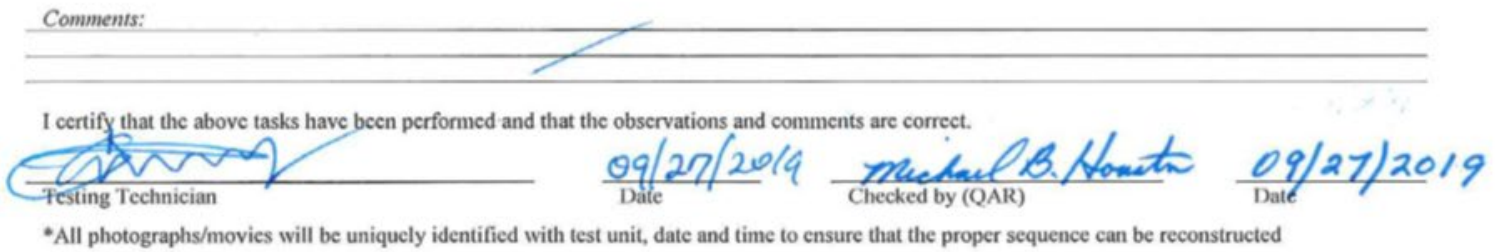

ORNLNTRC-084, Rev. 0 Apr-19 
TEST FORM 2 - Heat Test Checklist
Test Plan ORNL/NTRC-084

$\underline{\text { Rev. } 0}$

Test Unit 3
VERIFIED

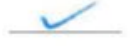

$\checkmark$
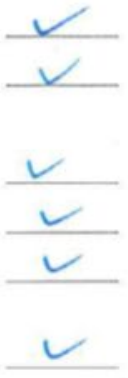

$\frac{u}{u}$
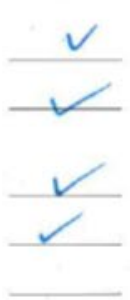

TASK

The test unit tray has been placed in the furnace.

Two calibrated Type $\mathrm{K}$ thermocouples have been installed in the working area of the furnace and attached to the Fluke thermocouple reader.

Thermocouple calibration date: $11-12-18$

The furnace doors have been closed and the furnace has been turned on with a set point of $850^{\circ} \mathrm{C}$

Thermocouple readings have been made every 60 minutes for at least 3 hours with a calibrated thermocouple reader Thermocouple reader model number 1303131 Calibration date: $11-12-18 \rightarrow 11-12-19$ Any changes in the furnace set pbint during the three-hour preheat period have been recorded on TEST FORM 3. Just prior to test unit insertion, a final preheat temperature recording was made.

Prior to opening the furnace ensure the operator has the proper PPE including gloves rated for work in 850 deg C atmosphere and a similarly rated face shield if required.

The furnace door has been opened, the test unit inserted, the furnace door closed, and the furnace activated with a set point of $850^{\circ} \mathrm{C}\left(1560^{\circ} \mathrm{F}\right)$ (or as adjusted during the preheat process).

When both thermocouple readings have reached $800^{\circ} \mathrm{C}\left(1475^{\circ} \mathrm{F}\right)$, the 10 -minute thermal test was started.

Thermocouple readings were taken and recorded on TEST FORM 4 every 30 seconds for the duration of the 10-minute thermal test.

Adjustments were made to the furnace set point as directed by the test director.

When the 10-minute test period was finished, the furnace was turned off and furnace door was opened to the maximum extent possible.

As soon as conditions permitted, the test unit was removed from the furnace and allowed to cool naturally.

Any deformation or other unusual circumstances regarding the test or the test unit was recorded.

Form has been signed and dated by the Quality Assurance Representative (QAR).

Comments:

No unsual deformation olsenvedy pictures wive taken.

After ru-2 remoral, the ferncee was allownd to heat-back-uf

above test temp. range bafore ju-3 woo mrented.

I certify that the above tasks have been performed and that the observations and comments are correct.
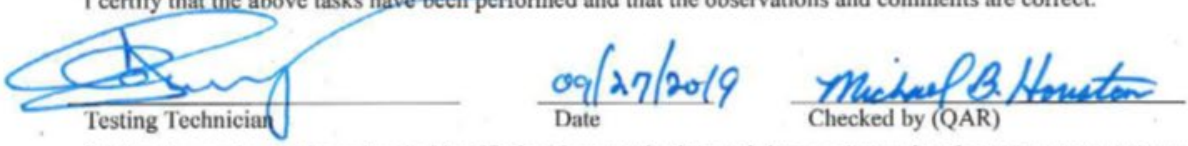

Checked by (QAR)

*All photographs will be uniquely identified with test unit, date and time to ensure that the proper sequence can be reconstructed 
TEST FORM 3 - Heat Test Preheat Data Sheet
Test Plan ORNL/NTRC-084

Rev. 0

Test Unit 3
VERIFIED

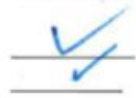

\section{TASK}

Record the temperature in the furnace every thirty (30) minutes for the duration of the preheat (at least 3 hours) Form has been signed and dated by the Quality Assurance Representative (QAR).

\begin{tabular}{|c|c|c|}
\hline Time $(\min )$ & ${ }^{\circ} \mathrm{C}$ Thermocouple 1 (OF) & ${ }^{\circ} \mathrm{C}$ Thermocouple 2 (OF) \\
\hline 0 & $853.9(1569.04)$ & $853.7(1568.7)$ \\
\hline 30 & $856.2(1573.2)$ & $854.1(1569.3)$ \\
\hline 60 & $854.8(1570.7)$ & $853.9(1569.2)$ \\
\hline 90 & $853.7(1568.6)$ & $850.7(1563.4)$ \\
\hline 120 & $855.1(1571.1)$ & $850.4(1562.7)$ \\
\hline 150 & $856.3(1573.2)$ & $852.8(1567.2)$ \\
\hline 180 & $857.2(1574.9)$ & $852.6(1566.8)$ \\
\hline & & \\
\hline & & \\
\hline & & \\
\hline
\end{tabular}

\begin{abstract}
Comments:

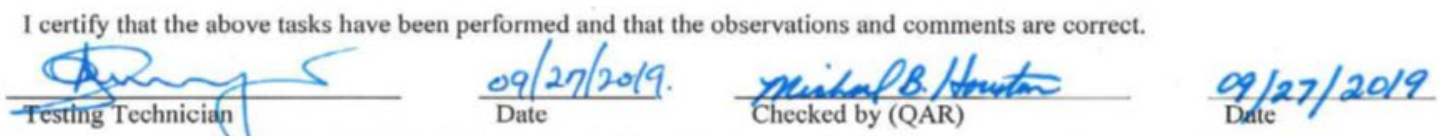

*All photographs/movies -vill be uniquely identified with test unit, date and time to ensure that the proper sequence can be reconstructed 
TEST FORM 4 - Heat Test Data Sheet

TASK

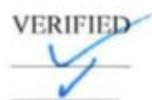

Record the temperature in the fumace every $\mathbf{3 0}$ seconds for the duration of the test

Form has been signed and dated by the Quality Assurance Representative (QAR).

\begin{tabular}{|c|c|c|}
\hline Time (min:sec) & Thermocouple I (Celsius) & Thermocouple 2 (Celsius) \\
\hline $00: 00$ & 822.5 & 834.9 \\
\hline 00:30 & 822.6 & 832.9 \\
\hline 01:00 & $823-0$ & 829.2 \\
\hline 01:30 & 821.0 & $838 \cdot 3$ \\
\hline 02:00 & $830-0$ & 837.1 \\
\hline $02: 30$ & 833.5 & 836.9 \\
\hline 03:00 & 832.3 & 836.0 \\
\hline 03:30 & $835=9$ & $840-0$ \\
\hline 04:00 & $834 \cdot 3$ & 843.4 \\
\hline 04:30 & 834.7 & $844 \cdot 4$ \\
\hline 05:00 & AA $836-3$ & $846 \cdot 9$ \\
\hline 05:30 & 841.4 & 847.9 \\
\hline 06:00 & 839.7 & 850.5 \\
\hline 06:30 & $843 \cdot 3$ & $844 \pi$ \\
\hline 07:00 & 839.8 & 848.1 \\
\hline 07:30 & 843.6 & 849.7 \\
\hline 08:00 & 840.6 & 857.2 \\
\hline 08:30 & 845.4 & $850 \cdot 3$ \\
\hline 09:00 & $845 \cdot 1$ & 853.8 \\
\hline 09:30 & $844-3$ & 856.6 \\
\hline $10: 00$ & $847 \cdot 3$ & 853.5 \\
\hline
\end{tabular}

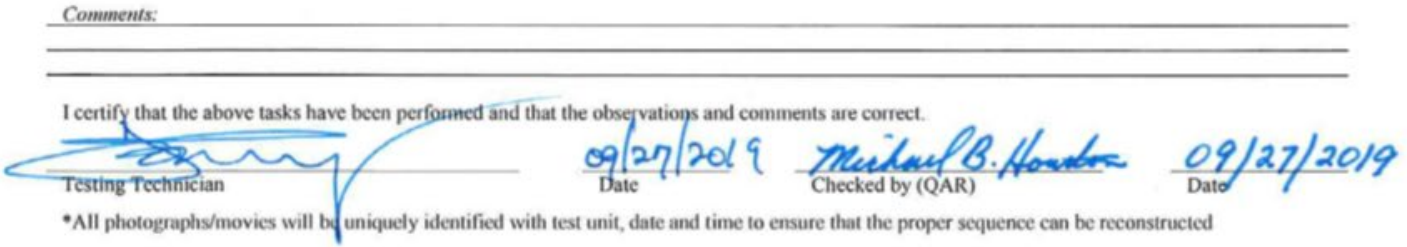

ORNL/NTRC-084, Rev. 0 Apr-19 


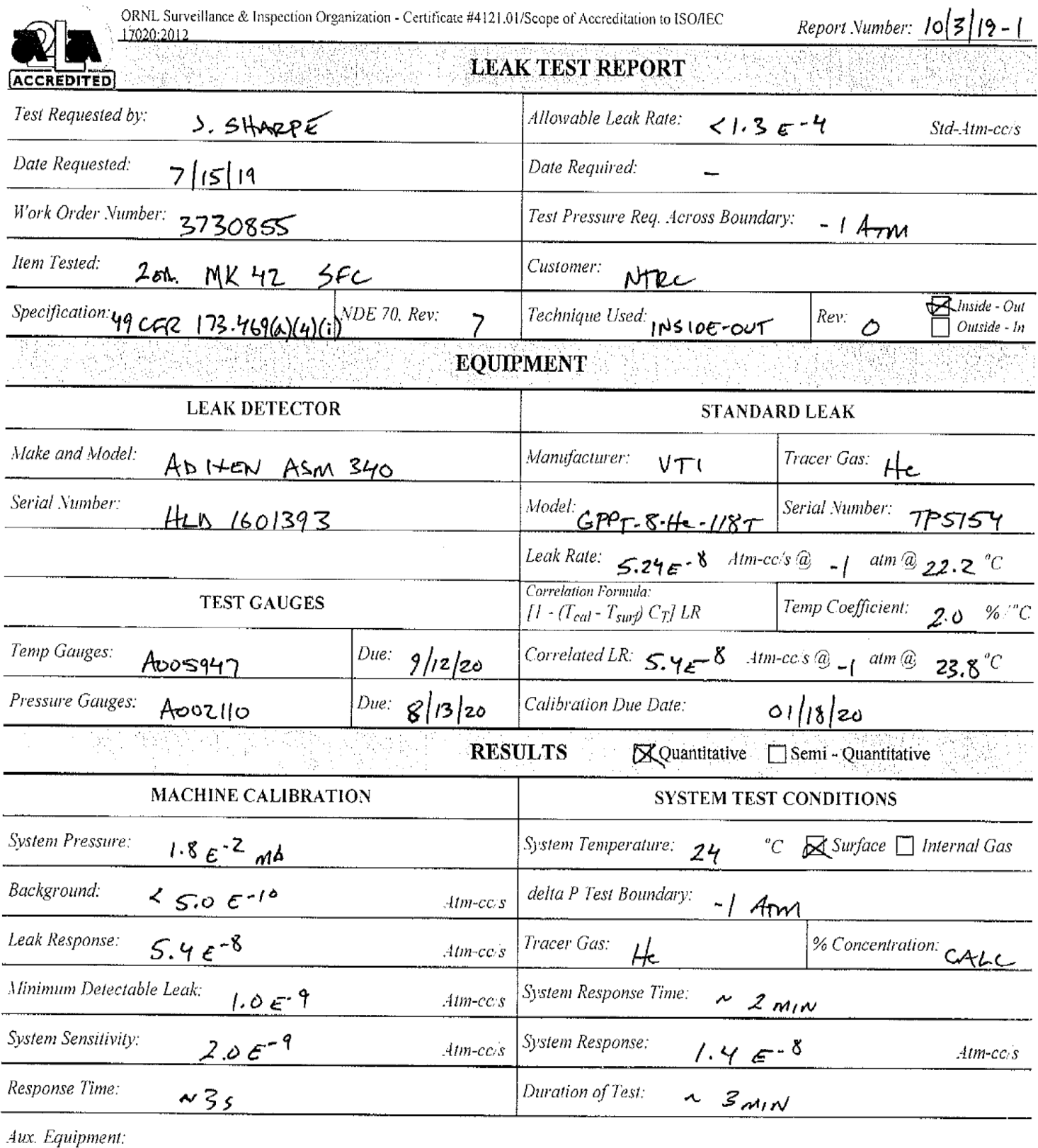

\begin{tabular}{|c|c|c|c|}
\hline 区ACCEPT & [ REJECT & 叉SKETCH / DATA ATTACHED & 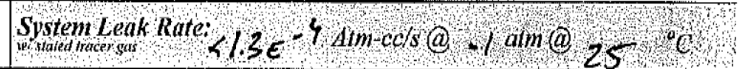 \\
\hline
\end{tabular}

TU-2, TU.3 POST-HEAT LEAK TEST

FINE - LT

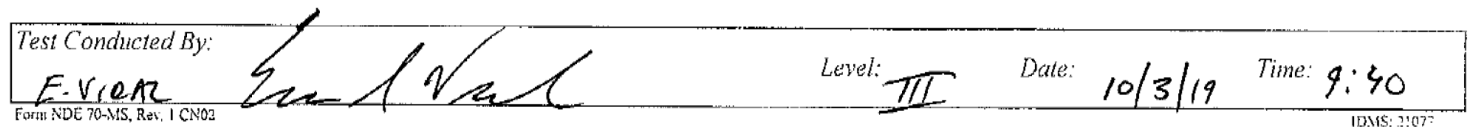


ORNL Surveillance and Inspection Organization / Certification Number: $412 \mathrm{~L} .0 \mathrm{~L} / \mathrm{Sc}$ ove of Accreditation to ISO/IEC 17020:2012

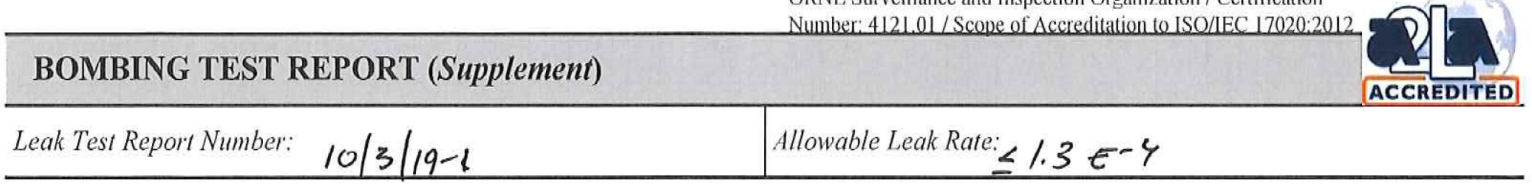

Item(s) Tested:

$$
\text { TU.2, TU.3 Mk } 42 \text { SFC }
$$

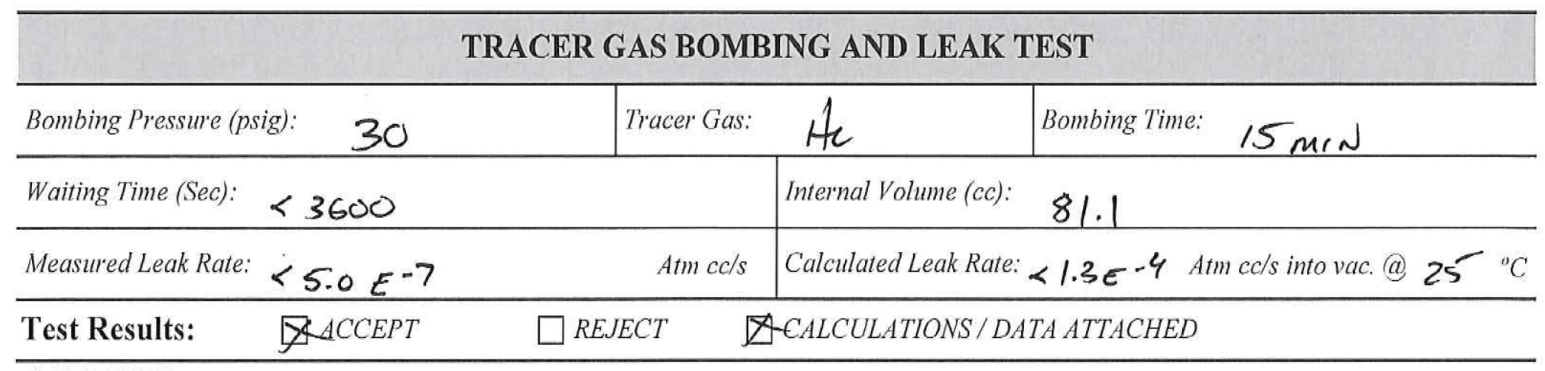

COMMENTS:

$$
\text { POST-HEAT LEAK TEST }
$$

E.vioar Lest Conducted By: Level:-II Date: 10/3/19




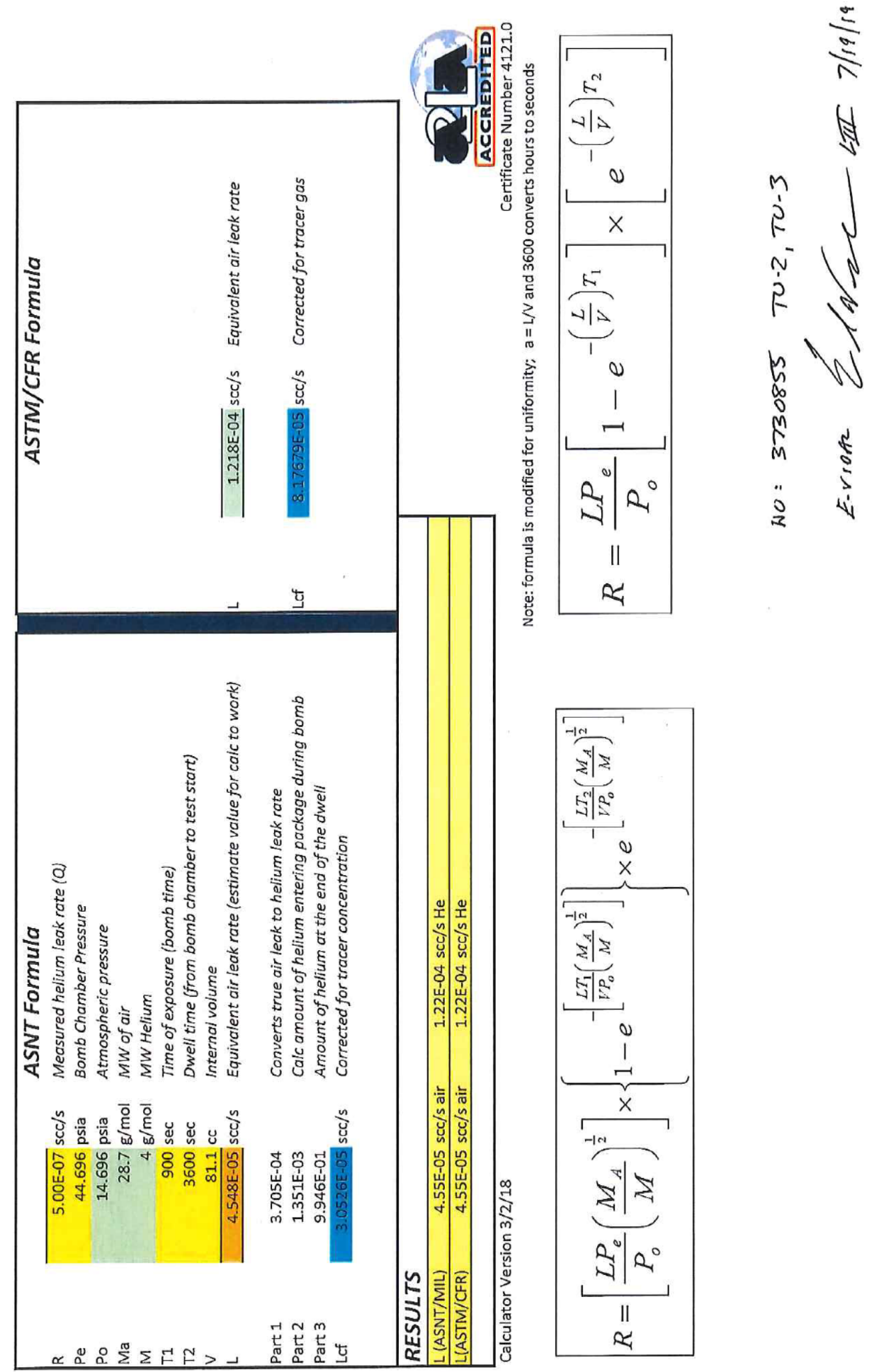




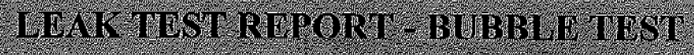

\begin{tabular}{|c|c|}
\hline Test Requested by: S. SHARPE & Customer: NTRC \\
\hline Date Requested: $\quad 7 / 15 / 19$ & Date Required: - \\
\hline Work Order Number: $\quad 3730855$ & \begin{tabular}{|l|l|l} 
NDE 70, Rev: 7 & Tech, NDE 70-BTRev: 0 \\
\end{tabular} \\
\hline Item Tested: TU.2, TU-3 Mk42 SFC & Test Pressure Required: - $15^{\prime \prime} \mathrm{Hy}$ \\
\hline Specification: 49 CFR $173.469($ a) (4)(i) & Inspection Criteria: NO BUBBLET \& $2 \mathrm{~m} / \mathrm{N}$ \\
\hline Technique Used: VAC BOX & Liquid Media Used: ImMers IT cimzooa $20 \%$ \\
\hline Test Gas Used: & Liquid Applicator Type: ImMersiow \\
\hline Inspection Light Intensity: $>100 \mathrm{FC}$ & Post Cleaning Method: \\
\hline
\end{tabular}

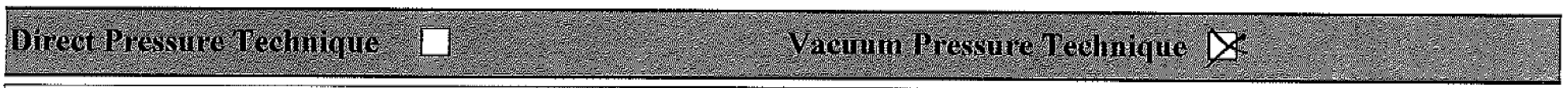

Component Limits of Test:

TEST SEQVENCE \#3 PER ORNLFNTRC-O84

$$
\text { POST.HEAT LT }
$$

\begin{tabular}{|c|c|c|c|c|c|c|c|}
\hline \multicolumn{4}{|c|}{ Component Test Site } & \multicolumn{4}{|c|}{ Component Installation Site } \\
\hline \multicolumn{4}{|c|}{ Gauges } & \multicolumn{2}{|c|}{ Test Pressure } & \multicolumn{2}{|c|}{ Temperature } \\
\hline \multirow[t]{2}{*}{$M f g$} & IDNO & $\begin{array}{c}\text { Calibration } \\
\text { Date }\end{array}$ & Range & Beginning & End & Beginning & End \\
\hline & $A 002124$ & $10 / 4 / 18$ & $0-30 " \mathrm{Ha}$ & $15^{\prime \prime} 14$ & $18 " \mathrm{Ha}$ & $238^{\circ} \mathrm{C}$ & $23.8^{\circ} \mathrm{C}$ \\
\hline
\end{tabular}

Temperature Measuring Device

\begin{tabular}{|l|l|l|l|l|}
\hline Mfg. OMEZA & Model HAl804 & Range K-TYPC & 1.0. Number ADos947 \\
\hline
\end{tabular}

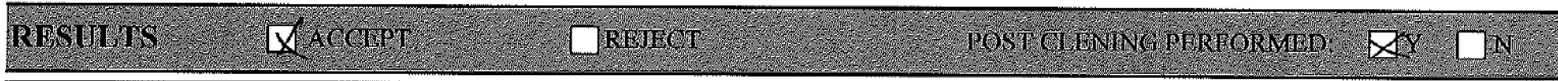

Comments;

$$
\text { GROSS LT }
$$

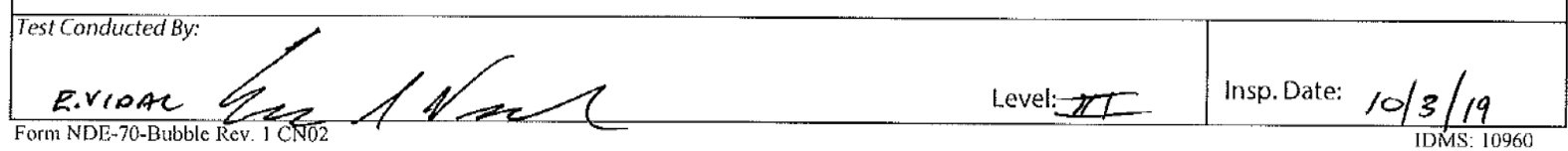


APPENDIX C. WELD INSPECTION REPORT 



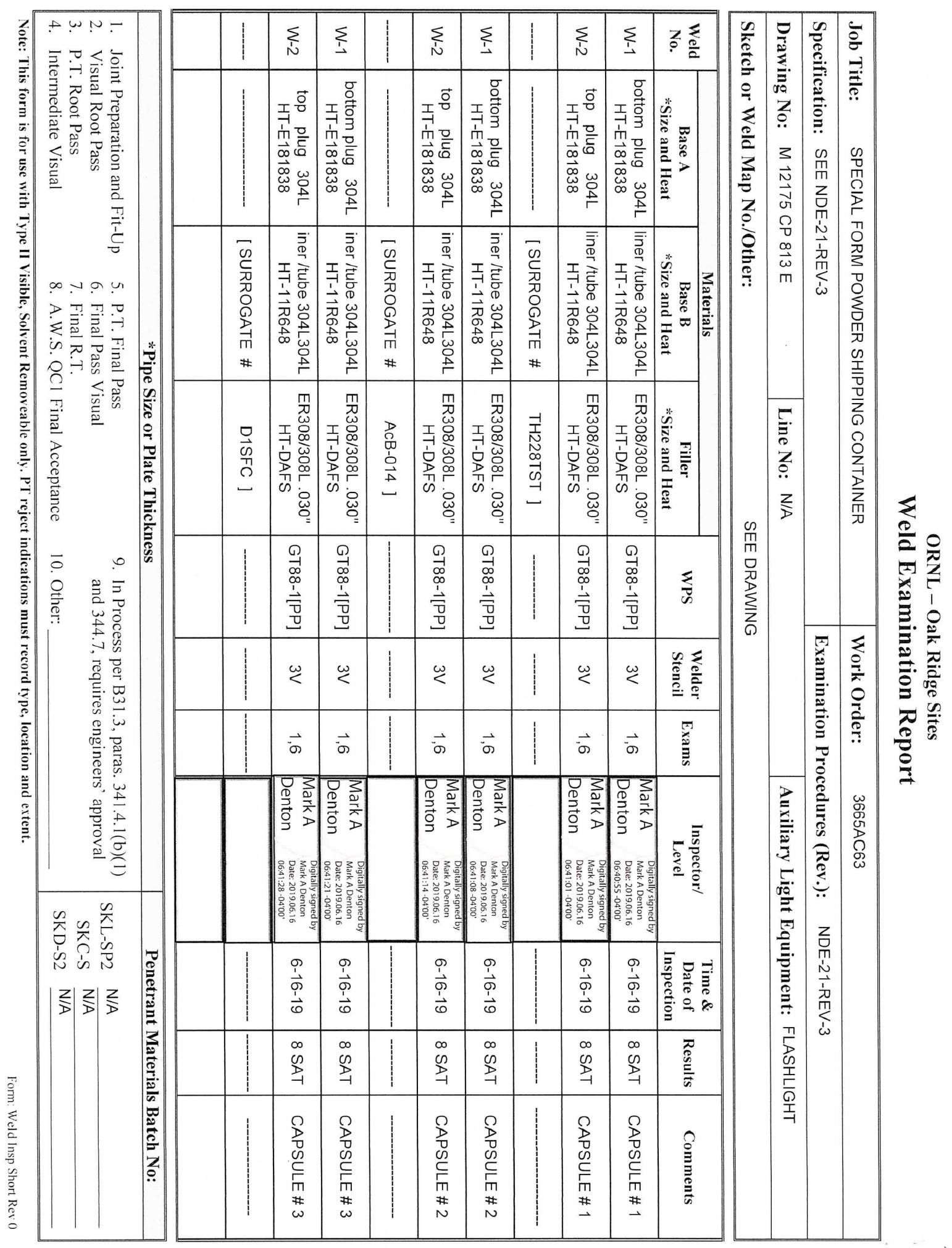


outokumpu Certificate of Test

high performance stainless steel

PRODEC QUALITY Page: 1

HEAT E181838 ORDER 684829/ 04 BOL 0245602 * CERTIEICATION * $12 / 17 / 18$

SHIP TO:

ROLLED ALLOYS BAR CENTER

711 PHOENIX LAKE AVENUE

STREAMWOOD

601070000

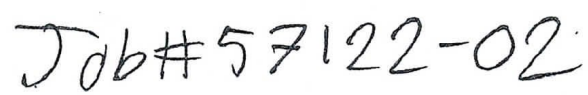

Outokumpu Stainless Bar, LLC 3043 Crenshaw Pkwy.
Richburg, SC 2.9729 . m nom

$0168505-$ STR

11/01/18 CUST\# 0773001 CUST TAG\#0009151

GRADE 304T 304

ITEM DESCRIPTIION

PRODEC QUALITY

Ship Condition CONDA

Size 3041 RND CEA CONDA $2.2500 \times 144.000$ RL
Country of Melt: UNITED KINGDOM Country of Mfg.: UNITED STATES

No wela repair

Eree of mercury contamination, Free of radiation contamination

No WEEE relevant substances; Meets RoHS-2011/65/EU and 2015/863

Total Bundles 1 Total Weight 2498 Approx. Hot Red. Ratio 8:1

WO 2091731 Bundles: 1 A

MEG TO FINISHED BAR IN THE USA EROM BILLETS MPORTED UNITED KINGDOM

AMS $5639 \mathrm{~J}, 5647 \mathrm{~K}$

ASME BPVC.II.A-2017 SA-182

ASME SA -4842017 Ed.

ASME SA-193 B8 2017 Edition

ASTM A 314.15

ASTM A484/A484M $18 \mathrm{a}$

ASTM A193 16 B8

NACE MR0175-09, ISO 15156:09

Eederal Spec QQ - S-763E

UNS 530403 , AISI 304 I

EN 10204 Type 3.1 Document

Prodec Quality

OTC is a prolongation of bar

No WEEE relevant substances

Bars are Eday Current tested

Sol Anneal at $1900 \mathrm{E}$ min/ Water Quench

SAE AMS-00-S-763D

ASME SA- 4792017 Ed.

ASME SA-320 B8 CLI, $2017 \mathrm{Ed}$

ASTM 182 A182M 18 a

ХSTM $276 / A 276 M 17$

ASTM A479/A479M 18

ASTM $\triangle 320$ 17a B8 Class 1

Solut j on Annealed Condition

DEAR $252.225 .700910 / 4 / 11$

UNS S30400, AISI 304

Free of Cont. carbide network

RA-53 RAM 304L

ASTM F899 $12 \mathrm{~b}$

DEARS $225,7002-3$ (B) (1)

Sol Ann $1900 \mathrm{E} \mathrm{min} / \mathrm{WQ}$
Hardness as shipped
Hardness as shipped
Grain size

Micro

Intergranular corrosion
MECHA
HRB
7.5

OK

Tensile strength, KSI (MPa)

$0.2 \%$ Yield Strngth, KSI (MPa)

88.7
38.3 $\left(\begin{array}{l}612 \\ 264\end{array}\right)$

Elongation \% in 4D

54.4

-- Continued -- 


\section{[5]}

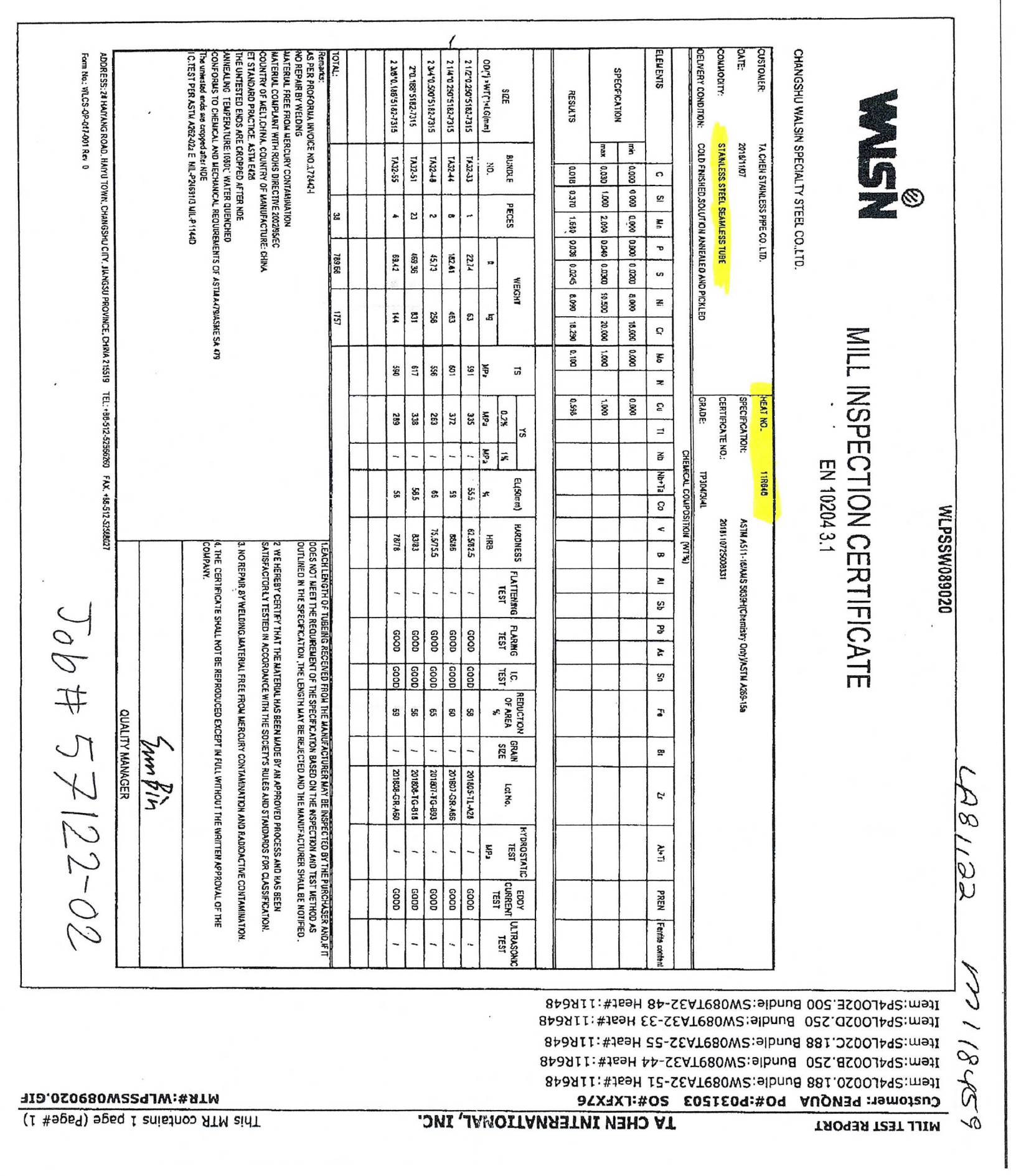




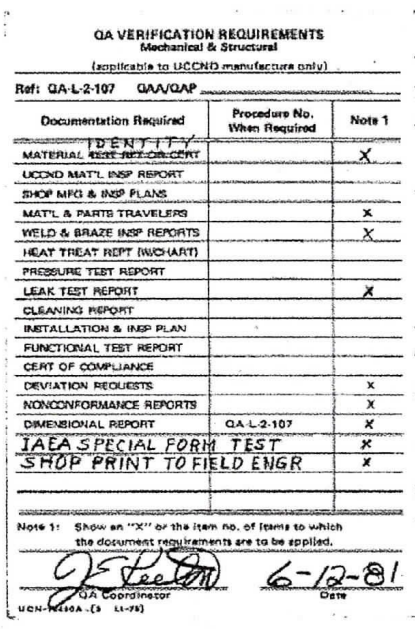

NOTES

1 WELO PLUG OPPOSITE GROOVEDEND IN PLACE

PLR OINL WFS 307 . INSPECT VISUALLY

2. LEAK TEST LINER BY METHOD SENSITIVE

TO $<1 \times 10^{-7} \mathrm{CC} / \mathrm{SEC}$

3. ALC MACHINE SURFACES TO BE 32

NOT NECESSARY TO M

T. COLLET REFERENCE SK DA

5. FUNNEL REFERENCE SK.85A

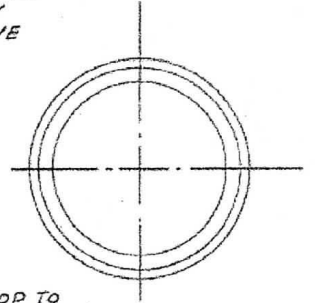

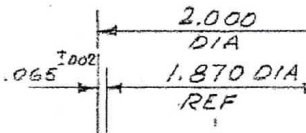

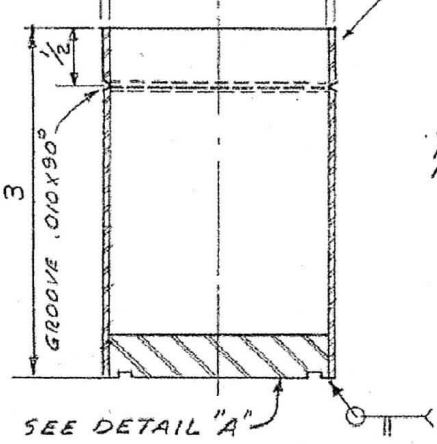

$\frac{\text { LINER EBOTTOM }}{\text { PIVE ASSEMPLY }}$

\section{MATER/AL:}

WINER. 3045 ST TUBING 2 "O.O.X .065 WALL PERASME $5 A-213$

PLUGS- $304 L$ S5T BAR PER

TOLERANCES UNLESS ANGLES I 10

SPECIAL FORM POWDER SHIPPING CONTAINER
PLUG FOR TOP TO

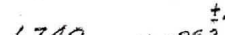
DETALL"
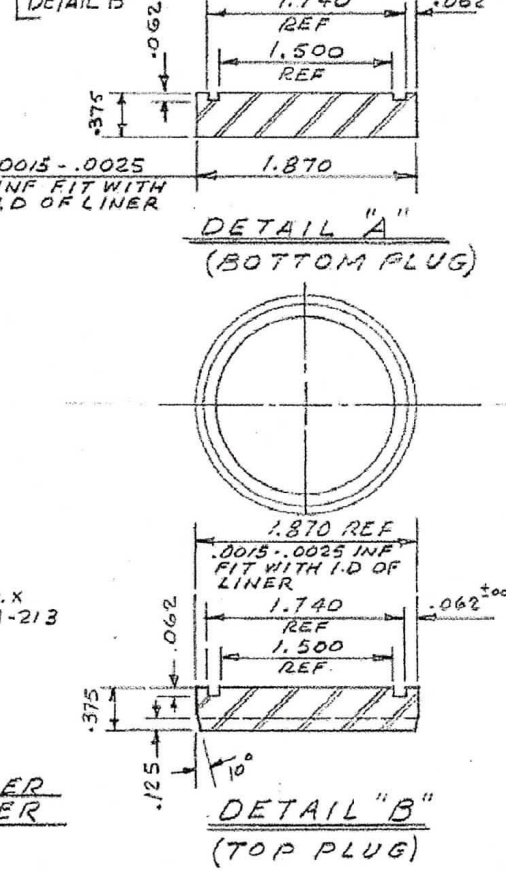

\begin{tabular}{|c|c|c|c|c|c|c|c|c|c|c|c|c|}
\hline \\
\hline & & & & & & & & & \multirow{2}{*}{\multicolumn{4}{|c|}{ 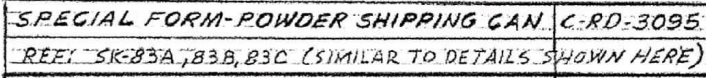 }} \\
\hline & & & & & & & & & & & & \\
\hline & & & & & & & & & \multicolumn{3}{|c|}{ REFERENCE DRAWINGS } & NUMBER \\
\hline & & & & & & & & & \multicolumn{4}{|c|}{$\begin{array}{l}\text { OAK RIDEE National LaboratoRY } \\
\text { OPERATED BY } \\
\text { UNION GARBIBE CORPORATIOH } \\
\text { OAK RIDGE, TENNESSEE }\end{array}$} \\
\hline & & & & & & & & & \multicolumn{4}{|c|}{ TPANSURANIUNA PROEESSING PLANT BLOG. 7920} \\
\hline $\begin{array}{l}\text { TOLERANCES UNLESS } \\
\text { OTHERWISE SPECIFIED }\end{array}$ & 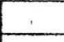 & \multicolumn{4}{|l|}{7} & 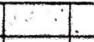 & & & \multicolumn{4}{|c|}{ SPEC/AL FORM } \\
\hline FRAGTONS $+\frac{1}{32}$ & No. & \multicolumn{4}{|c|}{ REVISIONS } & DATE & APPD & APPD & \multicolumn{4}{|c|}{ POWIDER SHIPPING CONTAINER } \\
\hline DECIMALS \pm & \multicolumn{2}{|c|}{ DRAWH } & DATE & SUBMTTEE. & DATE & NPAROVIEO & & DATE & \multicolumn{4}{|c|}{ AND ACCESSORIES } \\
\hline ANGLES $\pm 0^{\circ}-30$ & \multicolumn{2}{|c|}{ DESIGNED } & DATE & APPROVED & DXTE & APPROVED & & DATE & 5.0 Sestitis & 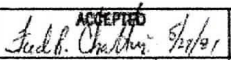 & \multicolumn{2}{|c|}{ Lefin $6 / 12 / 81$} \\
\hline SCALE: $\quad I^{\prime \prime}=l^{\prime}$ & \multicolumn{2}{|c|}{ CHECKED } & DUTE & APPROVED & DuTE & \multicolumn{2}{|l|}{ APPAOVED } & DAFE & HA & \begin{tabular}{l|l|}
12175 & $C P$ \\
\end{tabular} & 813 & T: \\
\hline
\end{tabular}




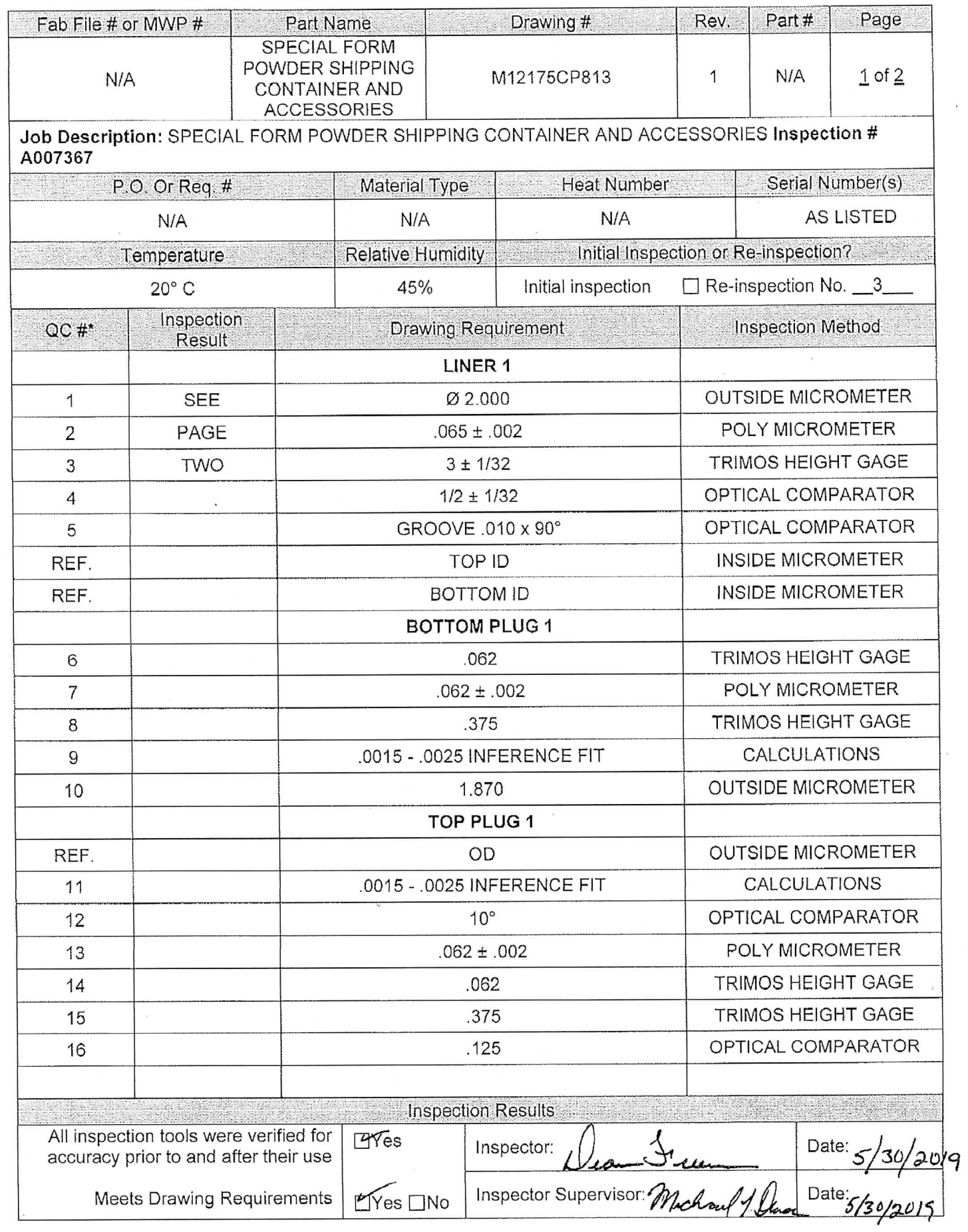




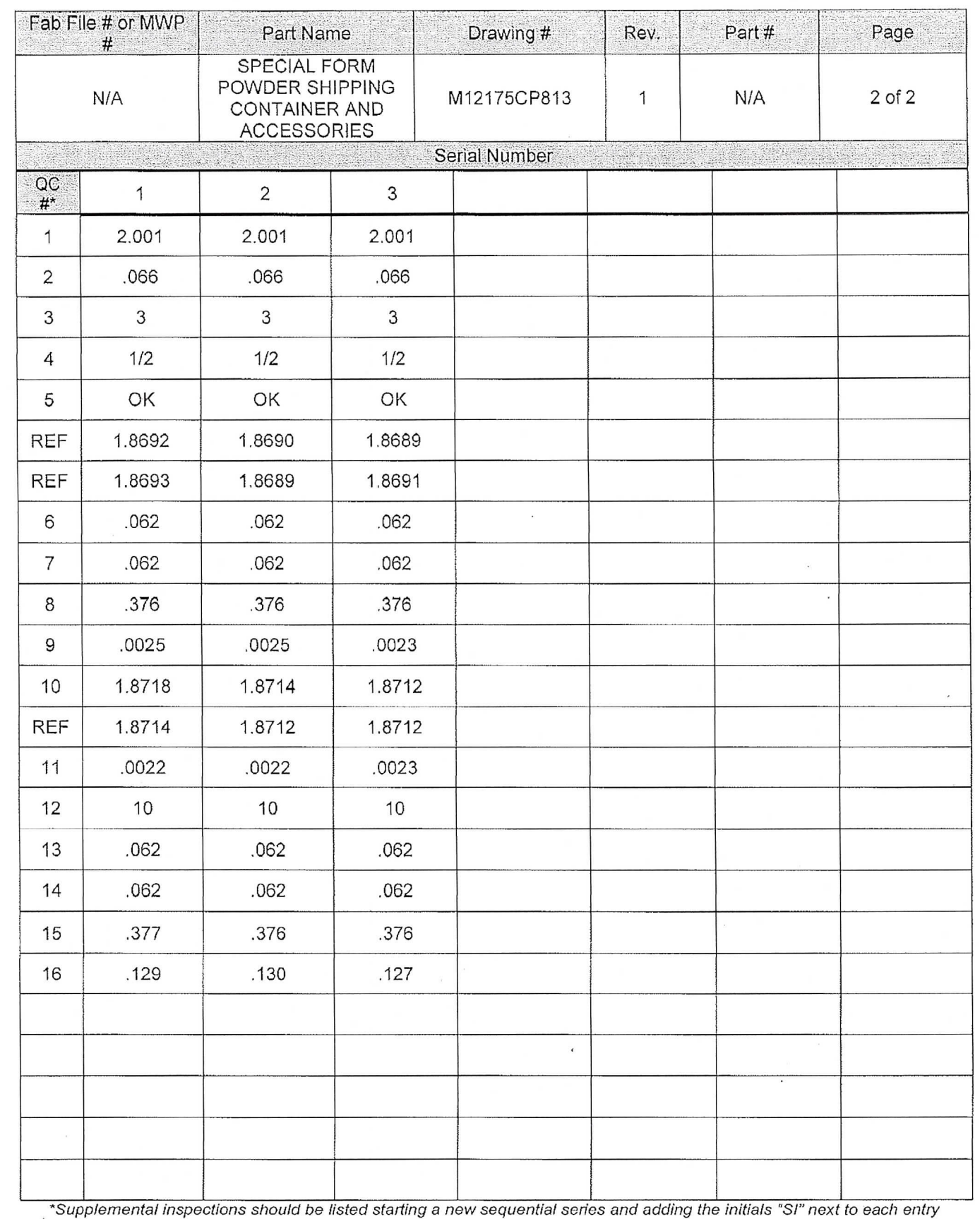




\section{APPENDIX D. LEAK TEST NDT EXAMINER TECHNICIAN CERTIFICATION}




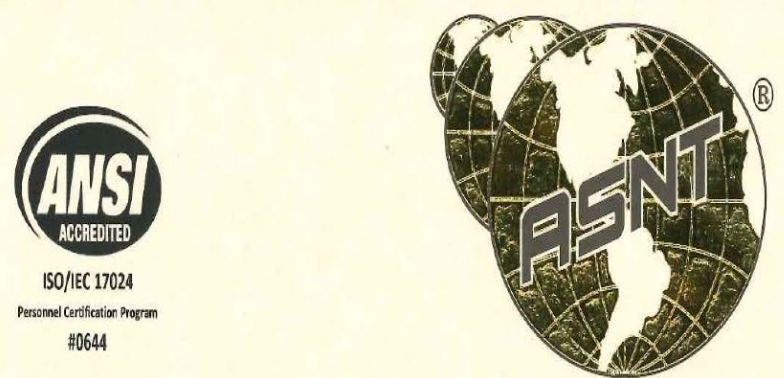

The American Society for Nondestructive Testing, Inc.

Be it known that

\section{Eric Steven Vidal}

has met the established and published Requirements for Certification by ASNT as

\section{NDT Level III}

in the following Nondestructive Testing Methods:

\begin{tabular}{lccc} 
Method & Issue Date & & Expiration Date \\
\cline { 2 - 2 } Leak Testing & $7 / 17$ & & $7 / 22$ \\
Liquid Penetrant Testing & $5 / 17$ & & $5 / 22$
\end{tabular}
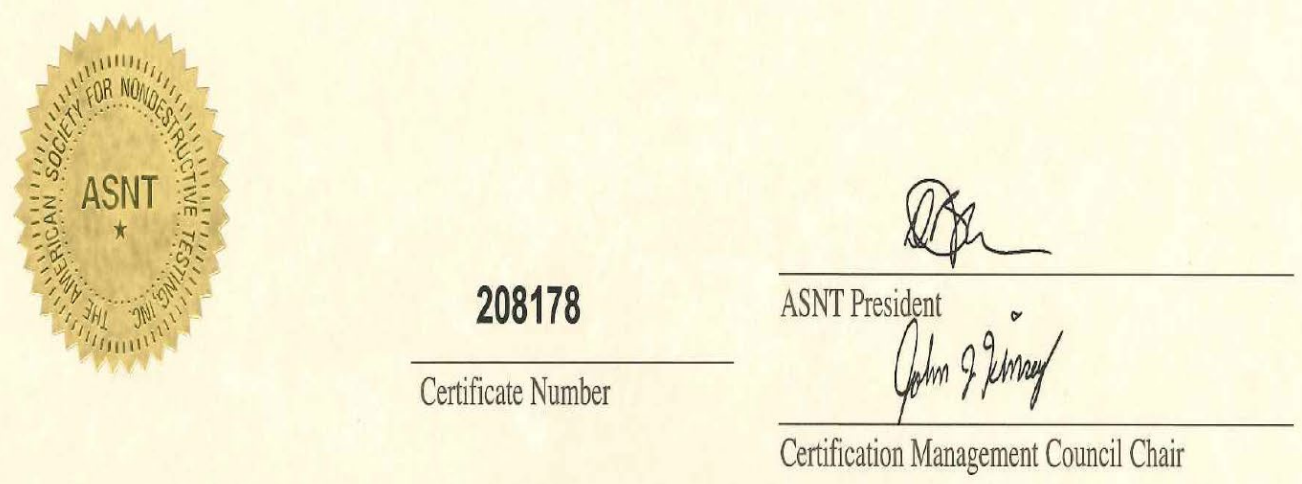

This certificate is the property of ASNT, is not official without ASNT's raised gold seal and is subject to revocation prior to the listed expiration date. This certificate should be verified on the ASNT website or by contacting the ASNT Technical Services Department. 



\section{APPENDIX E. LEAK TESTING PROCEDURE}

ORNL Leak Test Procedure (NDE-70 R.7) IS not available for public release. 

APPENDIX F. CALIBRATION RECORDS 



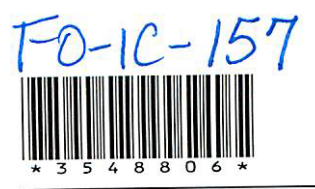

ORNL Work Order: 3548806

5. COAPLETED

Equipment: DATACQ-M303131 / Data acqusition-SCX
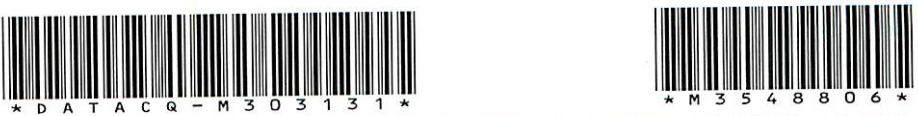

Work Description:

Location/Add'I Loc: 5700 3 1309

CB-V-IC-Calibration-G4-XF-1P-4H Variable Type

Service Org:

IC-RESCH/INST

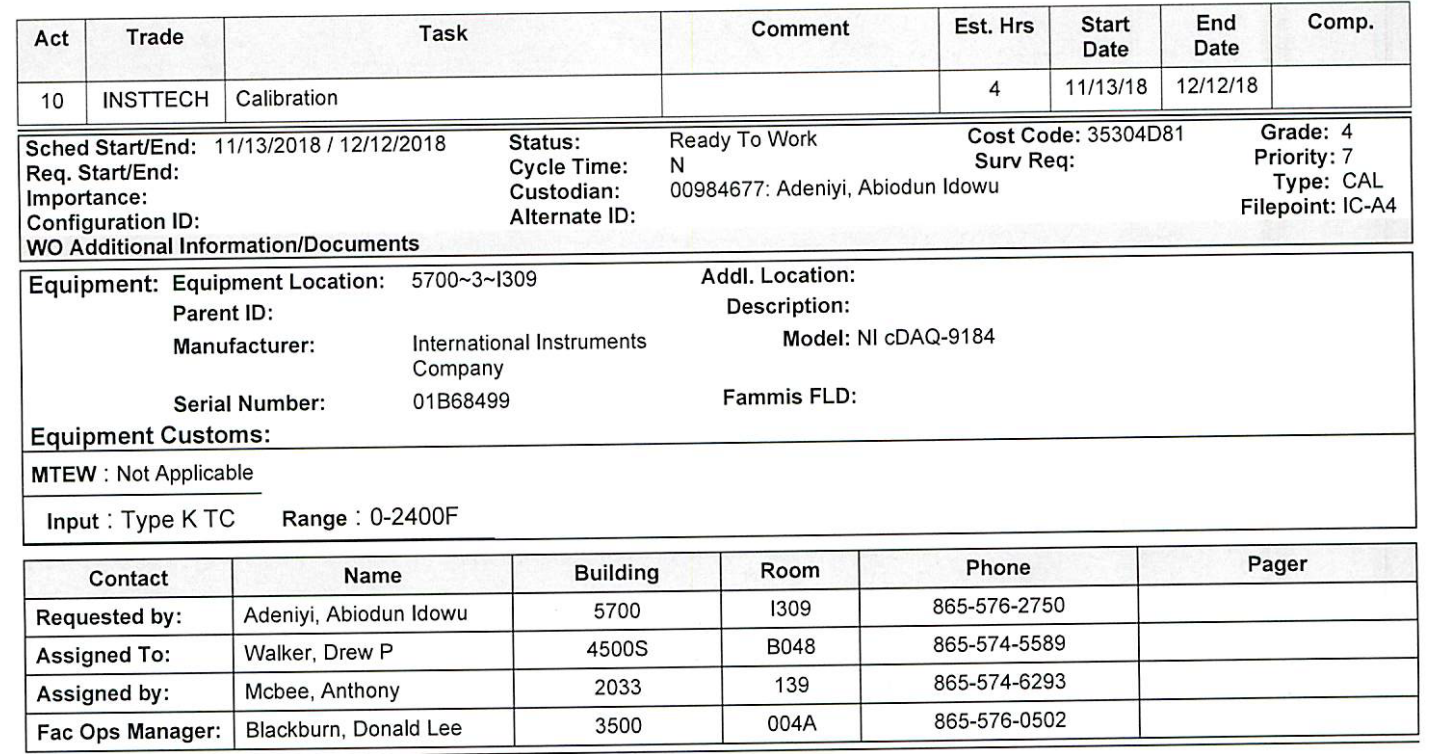

Safety (Grade 4 only) Answer the following for this job \& work location. Any Yes answer - contact the Task Leader for further

\begin{tabular}{|c|c|c|c|}
\hline & 1. & Yes & No \\
\hline & 2. & Yes & No \\
\hline & 3. & Yes & No \\
\hline & 4. & Yes & No \\
\hline & 5. & Yes & No \\
\hline & 6. & Yes & No \\
\hline
\end{tabular}

HPI Pre-Check Questions: Each worker should confirm readiness to begin the work (regardless of the Work Grade) by asking these or similar questions.

- What am I (are we) doing? - How are we going to respond in the event of a local, area or equipment alarm?

- What is the worst thing that can happen? How can $1 /$ we prevent it? What will $1 /$ we do if it does occur? - Are there lessons learned that should be considered? - What communication is needed during the task? How will we communicate?

Calibration:

\begin{tabular}{|c|c|c|c|c|c|c|c|c|}
\hline Seq & LABEL & INPUT & OUTPUT & TOLERANCE & ASFOUND & $\begin{array}{c}\text { Pass / Fail / } \\
\text { N/A }\end{array}$ & As Left & $\begin{array}{c}\text { Pass / Fail / } \\
\text { N/A }\end{array}$ \\
\hline 1 & $\begin{array}{l}\text { This captures diagnosis of } \\
\text { calibration only. Refer to } \\
\text { equipment documentation } \\
\text { to see actual calibration } \\
\text { data. 0-Pass 1-Pass w/Adj }\end{array}$ & 0 * & & 0 to +1 & * & & * & \\
\hline
\end{tabular}

Nov 21, 2018 8:57:11 AM

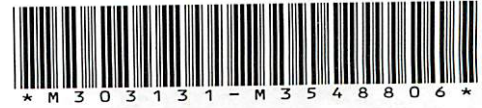


ORNL Work Order: 3548806

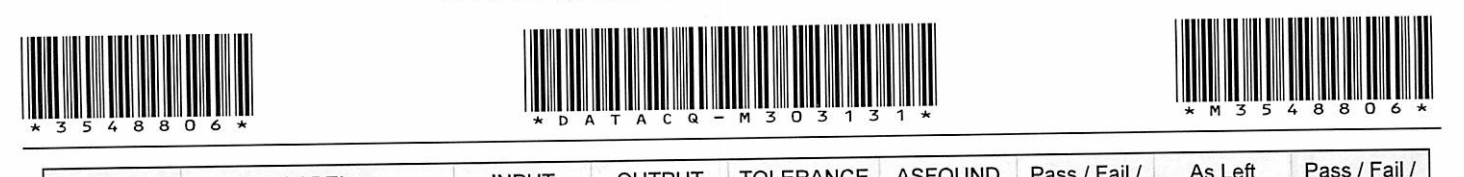

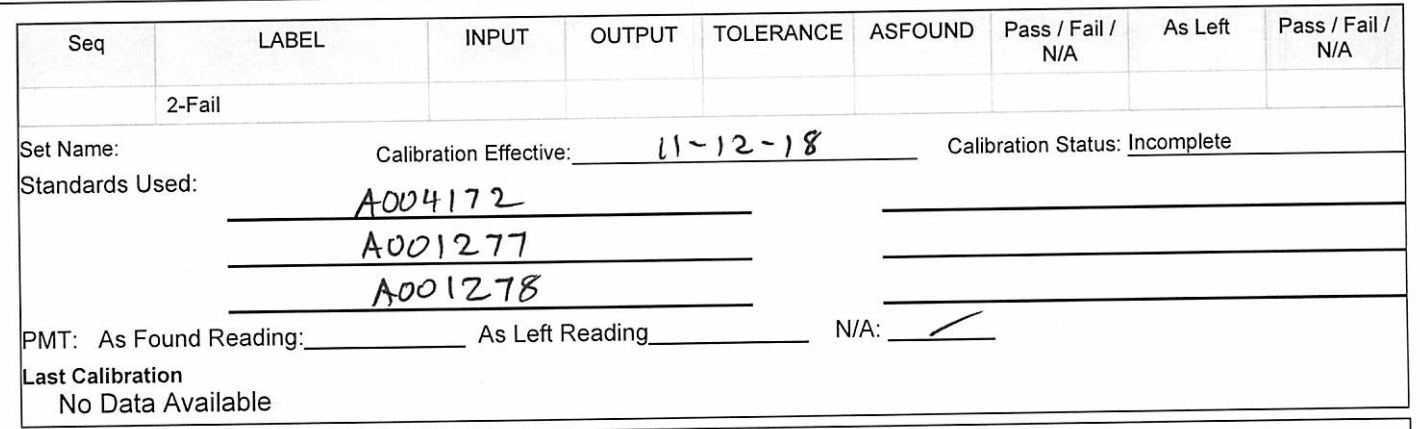

\section{Signatures:}

Person Notified:

Accepted By:

Reviewed by: leves WW

Date/Time:

osing: Completed: $\square$ Yes $\square$ No

Date: $\quad$ N/A [ ]

Closing:

Date: $11 / 28 / 18$ N/A [ ]

Comments:

Date Completed: $11-21-18$

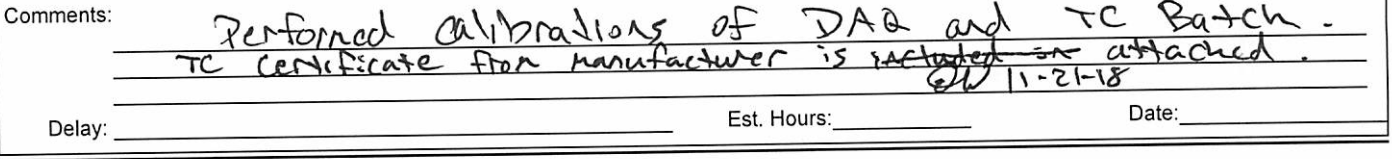

\begin{tabular}{|c|c|c|c|c|c|c|c|}
\hline Act. \# & Badge - Name & Date & Hours & Act. \# & Badge - Name & Date & Hours \\
\hline & & & & & & & \\
\hline & & & & & & & \\
\hline & & & & & & & \\
\hline
\end{tabular}

Booked Hours

Note: Only 10 time records will be displayed; See Total WO Booked Hours field for total hours.

Note: Only 10 time records will be displayed; See Total WO Booked Hours field for total hours.
\begin{tabular}{|c|l|c|c|}
\hline Act. \# & \multicolumn{1}{|c|}{ Badge - Name } & Date & Hours \\
\hline \multirow{2}{*}{10} & 03026591 - Walker, Drew P & Nov 12, 2018 & 0.5 \\
\cline { 2 - 3 } & 03026591 - Walker, Drew P & Total Hours for Activity 10 & 3 \\
\hline
\end{tabular}

\begin{tabular}{|l|l|}
\hline \hline Total Estimated Hours & Total Booked Hours \\
\hline
\end{tabular}

4

3.5

Nov 21, 2018 8:57:11 AM

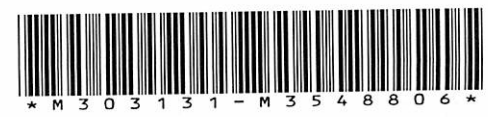


TECHNICIAN(s)/BADGE(s): $\quad 302659$

DATE: $11-12-18$

WORK ORDER \#: 3548806

ID\#: $\quad M 303131$

REVIEWED BY:

DATE:

GENERIC DATA SHEET FOR ELECTRONIC RECORDERS

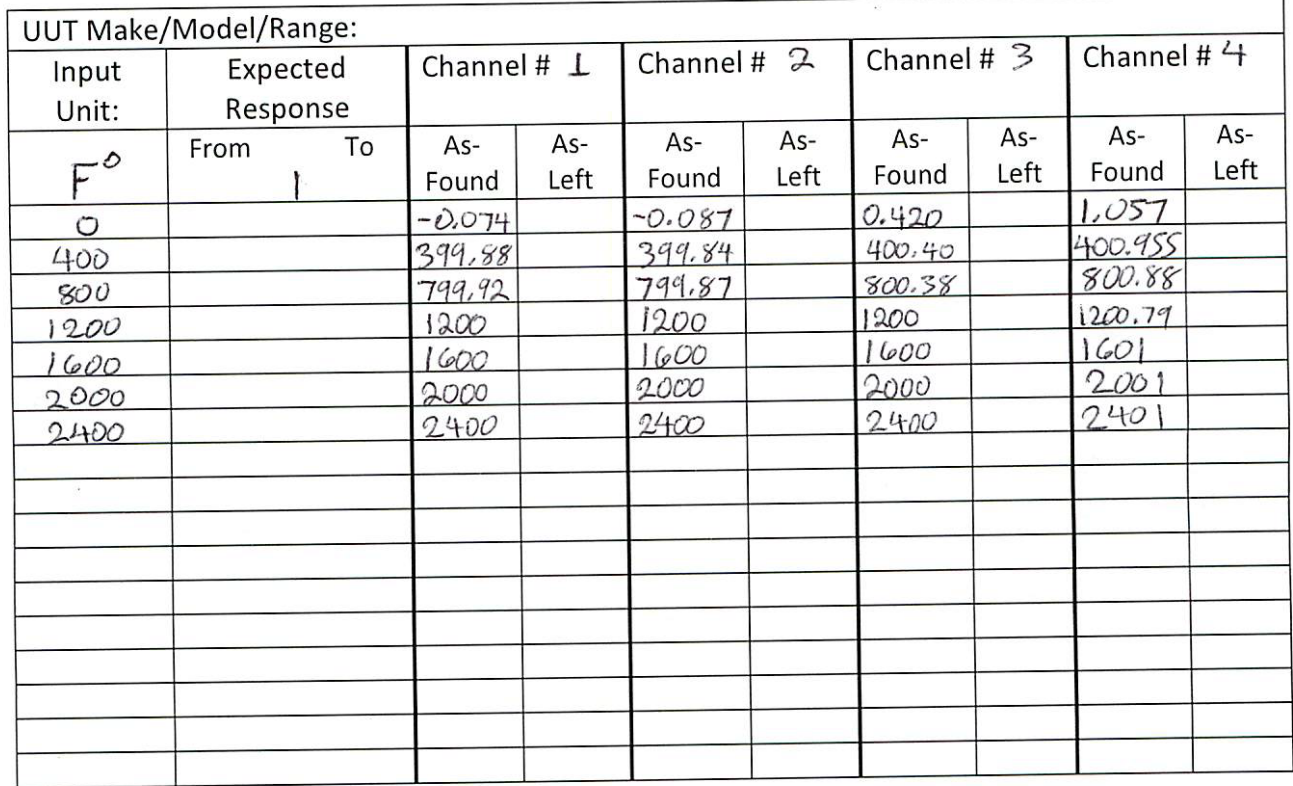

STANDARDS:

\begin{tabular}{|l|l|}
\hline ID Number: A004172 & Due Date: \\
\hline ID Number: & Due Date: \\
\hline ID Number: & Due Date: \\
\hline ID Number: & Due Date: \\
\hline
\end{tabular}

COMMENTS: Page $|-1|$ 
ICS/CREA1022-DS Rev. 04 (03/08/2017)

Page 1 of 1

Procedure: CALIBRATION OF ELECTRONIC RECORDERS

TECHNICIAN(s)/BADGE(s):

DATE:

WORK ORDER \#:

ID\#:

REVIEWED BY:

DATE:

GENERIC DATA SHEET FOR ELECTRONIC RECORDERS

\begin{tabular}{|c|c|c|c|c|c|c|c|c|c|}
\hline \multicolumn{10}{|c|}{ UUT Make/Model/Range: } \\
\hline \multirow{2}{*}{$\begin{array}{l}\text { Input } \\
\text { Unit: } \\
F^{0}\end{array}$} & $\begin{array}{l}\text { Expected } \\
\text { Response }\end{array}$ & \multicolumn{2}{|c|}{ Channel \# 5} & \multicolumn{2}{|c|}{ Channel \# 6} & \multicolumn{2}{|c|}{ Channel \# 7} & \multicolumn{2}{|c|}{ Channel \# 8} \\
\hline & From $\quad$ To & $\begin{array}{c}\text { As- } \\
\text { Found }\end{array}$ & $\begin{array}{l}\text { As- } \\
\text { Left }\end{array}$ & $\begin{array}{l}\text { As- } \\
\text { Found }\end{array}$ & $\begin{array}{l}\text { As- } \\
\text { Left }\end{array}$ & $\begin{array}{l}\text { As- } \\
\text { Found }\end{array}$ & $\begin{array}{l}\text { As- } \\
\text { Left }\end{array}$ & $\begin{array}{c}\text { As- } \\
\text { Found }\end{array}$ & $\begin{array}{l}\text { As- } \\
\text { Left }\end{array}$ \\
\hline 0 & & 0.633 & - & -0.054 & & $-0,046$ & & 0.301 & \\
\hline 400 & & 400.628 & & 399,96 & & 400.008 & & 400.369 & \\
\hline 800 & & 800.595 & & 799,933 & & 799,948 & & 799,964 & \\
\hline 1200 & & 1200,57 & & 1200 & & 1200 & & 1200 & \\
\hline 1600 & & 1601 & & 1600 & & 1600 & & 1600 & \\
\hline 2000 & & 2001 & & 2000 & & 2000 & & 2000 & \\
\hline 2400 & & 2401 & & 2400 & & 2400 & & 2400 & \\
\hline & & & & & & & & & \\
\hline & & & & & & & & & \\
\hline & & & & & & & & & \\
\hline & & & & & & & & & \\
\hline & & & & & & & & & \\
\hline & & & & & & & & & \\
\hline & & & & & & & & & \\
\hline & & & & & & & & & \\
\hline & & & & & & & & & \\
\hline & & & & & & & & & \\
\hline
\end{tabular}

STANDARDS:

\begin{tabular}{|l|l|}
\hline ID Number: & Due Date: \\
\hline ID Number: & Due Date: \\
\hline ID Number: & Due Date: \\
\hline ID Number: & Due Date: \\
\hline
\end{tabular}

comments: Continuation 2-11 
ICS/CREA1022-DS Rev. 04 (03/08/2017)

Page 1 of 1

Procedure: CALIBRATION OF ELECTRONIC RECORDERS

IDMS: \# 20566

TECHNICIAN(s)/BADGE(s):

DATE:

WORK ORDER \#:

ID\#:

REVIEWED BY:

DATE:

GENERIC DATA SHEET FOR ELECTRONIC RECORDERS

\begin{tabular}{|c|c|c|c|c|c|c|c|c|c|c|}
\hline \multicolumn{11}{|c|}{ UUT Make/Model/Range: } \\
\hline \multirow{2}{*}{$\begin{array}{l}\text { Input } \\
\text { Unit: } \\
\text { OF }\end{array}$} & \multicolumn{2}{|c|}{$\begin{array}{l}\text { Expected } \\
\text { Response }\end{array}$} & \multicolumn{2}{|c|}{ Channel \# 9} & \multicolumn{2}{|c|}{ Channel \# 10} & \multicolumn{2}{|c|}{ Channel \# II } & \multicolumn{2}{|c|}{ Channel \# 12} \\
\hline & From & To & $\begin{array}{l}\text { As- } \\
\text { Found }\end{array}$ & $\begin{array}{l}\text { As- } \\
\text { Left }\end{array}$ & $\begin{array}{l}\text { As- } \\
\text { Found }\end{array}$ & $\begin{array}{l}\text { As- } \\
\text { Left }\end{array}$ & $\begin{array}{l}\text { As- } \\
\text { Found }\end{array}$ & $\begin{array}{l}\text { As- } \\
\text { Left }\end{array}$ & $\begin{array}{c}\text { As- } \\
\text { Found }\end{array}$ & $\begin{array}{l}\text { As- } \\
\text { Left }\end{array}$ \\
\hline 0 & & & 0.228 & & 0.217 & & 0.185 & & 0.167 & \\
\hline 400 & & & 400.276 & & 400,276 & & 400,23 & & 400,244 & \\
\hline 800 & & & 800.253 & & 800,236 & & 800.206 & & 800.212 & \\
\hline 1200 & & & 1200 & & 1200 & & 1200 & & 1200 & \\
\hline 1600 & & & 1600 & & 1600 & & 1600 & & 1600 & \\
\hline 2000 & & & 2000 & & 2000 & & 2000 & & 2000 & \\
\hline 2400 & & & 2400 & & 2400 & & 2400 & & 2400 & \\
\hline & & & & & & & & & & \\
\hline & & & & & & & & & & \\
\hline & & & & & & & & & & \\
\hline & & & & & & & & & & \\
\hline & & & & & & & & & & \\
\hline & & & & & & & & & & \\
\hline & & & & & & & & & & \\
\hline & & & & & & & & & & \\
\hline & & & & & & & & & & \\
\hline & & & & & & & & & & \\
\hline
\end{tabular}

STANDARDS:

\begin{tabular}{|l|l|}
\hline ID Number: & Due Date: \\
\hline ID Number: & Due Date: \\
\hline ID Number: & Due Date: \\
\hline ID Number: & Due Date: \\
\hline
\end{tabular}

COMMENTS:

Continuation

$3-11$ 
DATA SHEET

ICS/CREA1022-DS Rev. 04 (03/08/2017)

Procedure: CALIBRATION OF ELECTRONIC RECORDERS

IDMS: \# 20566

TECHNICIAN(s)/BADGE(s):

DATE:

WORK ORDER \#:

ID\#:

REVIEWED BY:

DATE:

GENERIC DATA SHEET FOR ELECTRONIC RECORDERS

\begin{tabular}{|c|c|c|c|c|c|c|c|c|c|}
\hline \multicolumn{10}{|c|}{ UUT Make/Model/Range: } \\
\hline $\begin{array}{l}\text { Input } \\
\text { Unit: }\end{array}$ & $\begin{array}{l}\text { Expected } \\
\text { Response }\end{array}$ & \multicolumn{2}{|c|}{ Channel \# 13} & \multicolumn{2}{|c|}{ Channel \# 14} & \multicolumn{2}{|c|}{ Channel \# 15} & \multicolumn{2}{|c|}{ Channel \# 16} \\
\hline OF & From $\quad$ To & $\begin{array}{l}\text { As- } \\
\text { Found }\end{array}$ & $\begin{array}{l}\text { As- } \\
\text { Left }\end{array}$ & $\begin{array}{c}\text { As- } \\
\text { Found }\end{array}$ & $\begin{array}{l}\text { As- } \\
\text { Left }\end{array}$ & $\begin{array}{c}\text { As- } \\
\text { Found }\end{array}$ & $\begin{array}{l}\text { As- } \\
\text { Left }\end{array}$ & $\begin{array}{c}\text { As- } \\
\text { Found }\end{array}$ & $\begin{array}{l}\text { As- } \\
\text { Left }\end{array}$ \\
\hline 0 & & 0,066 & & 0.173 & & 0.182 & & 0.141 & \\
\hline 400 & & 400,144 & & 400.266 & & 400,177 & & 400,173 & \\
\hline 800 & & 800,166 & & 800,228 & & 80.175 & & 800,125 & \\
\hline 1200 & & 1200 & & 1200 & & 1200 & & 1200 & \\
\hline 1600 & & 1600 & & 1600 & & 1600 & & 1600 & \\
\hline 2000 & & 2000 & & 2000 & & 2000 & & 2000 & \\
\hline 2400 & & 2400 & & 2400 & & 2400 & & 2400 & \\
\hline & & & & & & & & & \\
\hline & & & & & & & & & \\
\hline & & & & & & & & & \\
\hline & & & & & & & & & \\
\hline & & & & & & & & & \\
\hline & & & & & & & & & \\
\hline & & & & & & & & & \\
\hline & & & & & & & & & \\
\hline & & & & & & & & & \\
\hline & & & & & & & & & \\
\hline
\end{tabular}

STANDARDS:

\begin{tabular}{|l|l|}
\hline ID Number: & Due Date: \\
\hline ID Number: & Due Date: \\
\hline ID Number: & Due Date: \\
\hline ID Number: & Due Date: \\
\hline
\end{tabular}

COMMENTS: Continuation 4-11 
ICS/CREA1022-DS Rev. 04 (03/08/2017)

Procedure: CALIBRATION OF ELECTRONIC RECORDERS

IDMS: \# 20566

TECHNICIAN(s)/BADGE(s):

DATE:

WORK ORDER \#:

ID\#:

REVIEWED BY:

DATE:

GENERIC DATA SHEET FOR ELECTRONIC RECORDERS

\begin{tabular}{|c|c|c|c|c|c|c|c|c|c|c|}
\hline \multicolumn{11}{|c|}{ UUT Make/Model/Range: } \\
\hline $\begin{array}{l}\text { Input } \\
\text { Unit: }\end{array}$ & \multicolumn{2}{|c|}{$\begin{array}{l}\text { Expected } \\
\text { Response }\end{array}$} & \multicolumn{2}{|c|}{ Channel \# 17} & \multicolumn{2}{|c|}{ Channel \# 18} & \multicolumn{2}{|c|}{ Channel \# 19} & \multicolumn{2}{|c|}{ Channel \#20 } \\
\hline${ }^{\circ} \mathrm{F}$ & From & To & $\begin{array}{l}\text { As- } \\
\text { Found }\end{array}$ & $\begin{array}{l}\text { As- } \\
\text { Left }\end{array}$ & $\begin{array}{l}\text { As- } \\
\text { Found }\end{array}$ & $\begin{array}{l}\text { As- } \\
\text { Left }\end{array}$ & $\begin{array}{l}\text { As- } \\
\text { Found }\end{array}$ & $\begin{array}{l}\text { As- } \\
\text { Left }\end{array}$ & $\begin{array}{l}\text { As- } \\
\text { Found }\end{array}$ & $\begin{array}{l}\text { As- } \\
\text { Left }\end{array}$ \\
\hline 0 & & & -0.164 & & -0.252 & & -0.050 & & -0.110 & \\
\hline 400 & & & 399.89 & & 399.85 & & 349.959 & & 399.929 & \\
\hline 800 & & & 799,871 & & 799.918 & & 799.941 & & 799.842 & \\
\hline 1200 & & & 1200 & & 1200 & & 1200 & & 1200 & \\
\hline 1600 & & & 1600 & & 1600 & & 1600 & & 1600 & \\
\hline 2000 & & & 2000 & & 2000 & & 2000 & & 2000 & \\
\hline 2400 & & & 2400 & & 2400 & & 2400 & & 2400 & \\
\hline & & & & & & & & & & \\
\hline & & & & & & & & & & \\
\hline & & & & & & & & & & \\
\hline & & & & & & & & & & \\
\hline & & & & & & & & & & \\
\hline & & & & & & & & & & \\
\hline & & & & & & & & & & \\
\hline & & & & & & & & & & \\
\hline & & & & & & & & & & \\
\hline & & & & & & & & & & \\
\hline
\end{tabular}

STANDARDS:

\begin{tabular}{|l|l|}
\hline ID Number: & Due Date: \\
\hline ID Number: & Due Date: \\
\hline ID Number: & Due Date: \\
\hline ID Number: & Due Date: \\
\hline
\end{tabular}

COMMENTS:

Continuation

$5-11$ 
ICS/CREA1022-DS Rev. 04 (03/08/2017)

Page 1 of 1

Procedure: CALIBRATION OF ELECTRONIC RECORDERS

IDMS: \# 20566

TECHNICIAN(s)/BADGE(s):

DATE:

WORK ORDER \#:

ID\#:

REVIEWED BY:

DATE:

GENERIC DATA SHEET FOR ELECTRONIC RECORDERS

\begin{tabular}{|c|c|c|c|c|c|c|c|c|c|c|}
\hline \multicolumn{11}{|c|}{ UUT Make/Model/Range: } \\
\hline $\begin{array}{l}\text { Input } \\
\text { Unit: }\end{array}$ & \multicolumn{2}{|c|}{$\begin{array}{l}\text { Expected } \\
\text { Response }\end{array}$} & \multicolumn{2}{|c|}{ Channel \#21 } & \multicolumn{2}{|c|}{ Channel \#22 } & \multicolumn{2}{|c|}{ Channel \#23 } & \multicolumn{2}{|c|}{ Channel \#24 } \\
\hline${ }^{\circ} \mathrm{F}$ & From & To & $\begin{array}{c}\text { As- } \\
\text { Found }\end{array}$ & $\begin{array}{l}\text { As- } \\
\text { Left }\end{array}$ & $\begin{array}{l}\text { As- } \\
\text { Found }\end{array}$ & $\begin{array}{l}\text { As- } \\
\text { Left }\end{array}$ & $\begin{array}{l}\text { As- } \\
\text { Found }\end{array}$ & $\begin{array}{l}\text { As- } \\
\text { Left }\end{array}$ & $\begin{array}{l}\text { As- } \\
\text { Found }\end{array}$ & $\begin{array}{l}\text { As- } \\
\text { Left }\end{array}$ \\
\hline 0 & & & -0.308 & & -0.167 & & $-0-205$ & & -0.184 & \\
\hline 400 & & & 399,755 & & 399,859 & & 399,836 & & 399.807 & \\
\hline 800 & & & 799,785 & & 799.801 & & 799.864 & & 799.893 & \\
\hline 1200 & & & 1200 & & 1200 & & 1200 & & 1200 & \\
\hline 1600 & & & 1600 & & 1600 & & 1600 & & 1600 & \\
\hline 2000 & & & 2000 & & 2000 & & 2000 & & 2000 & \\
\hline 2400 & & & 2400 & & 2400 & & 2400 & & 2400 & \\
\hline & & & & & & & & & & \\
\hline & & & & & & & & & & \\
\hline & & & & & & & & & & \\
\hline & & & & & & & & & & \\
\hline & & & & & & & & & & \\
\hline & & & & & & & & & & \\
\hline & & & & & & & & & & \\
\hline & & & & & & & & & & \\
\hline & & & & & & & & & & \\
\hline & & & & & & & & & & \\
\hline
\end{tabular}

STANDARDS:

\begin{tabular}{|l|l|}
\hline ID Number: & Due Date: \\
\hline ID Number: & Due Date: \\
\hline ID Number: & Due Date: \\
\hline ID Number: & Due Date: \\
\hline
\end{tabular}

COMMENTS:

Continuation

$6-11$ 
DATA SHEET

ICS/CREA1022-DS Rev. 04 (03/08/2017)

Page 1 of 1

Procedure: CALIBRATION OF ELECTRONIC RECORDERS

IDMS: \# 20566

TECHNICIAN(s)/BADGE(s):

DATE:

WORK ORDER \#:

ID\#:

REVIEWED BY:

DATE:

GENERIC DATA SHEET FOR ELECTRONIC RECORDERS

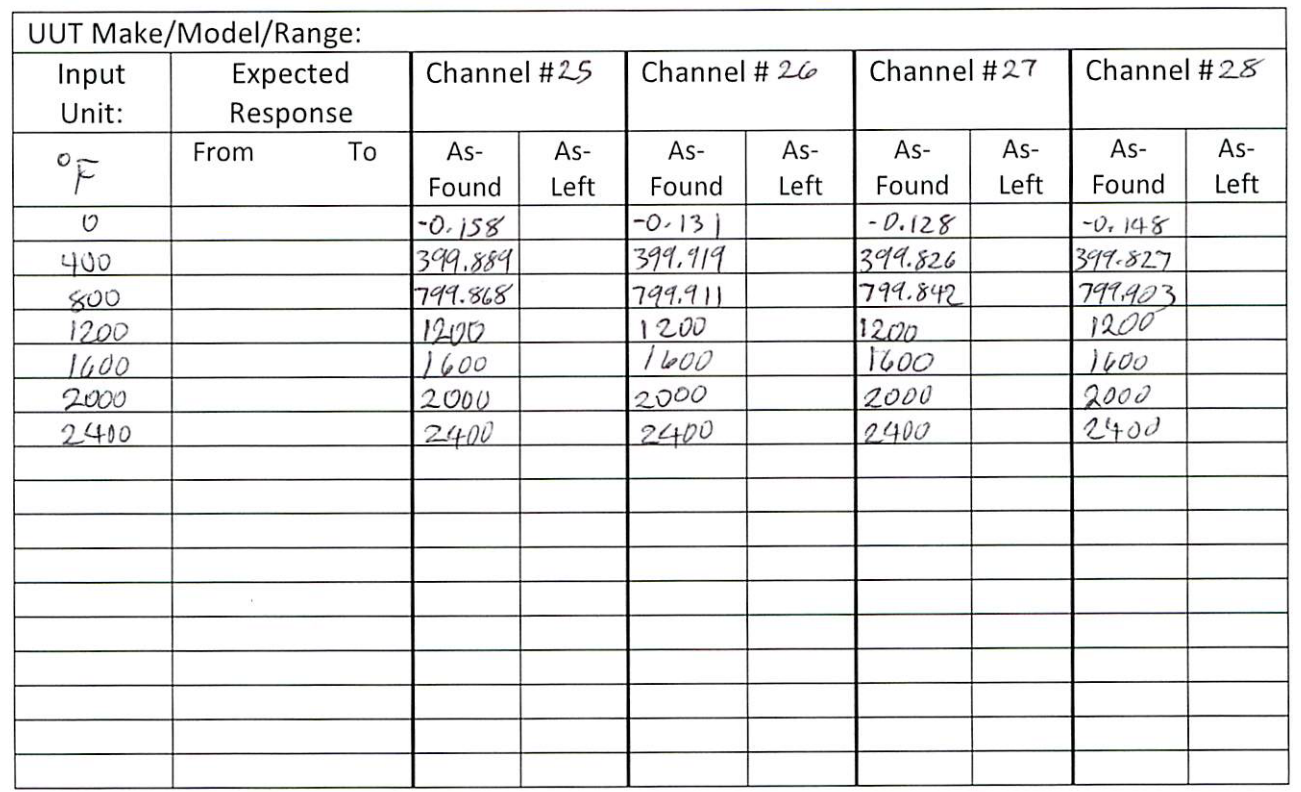

STANDARDS

\begin{tabular}{|l|l|}
\hline ID Number: & Due Date: \\
\hline ID Number: & Due Date: \\
\hline ID Number: & Due Date: \\
\hline ID Number: & Due Date: \\
\hline
\end{tabular}

COMMENTS: Continuation 7-11 
ICS/CREA1022-DS Rev. 04 (03/08/2017)

Procedure: CALIBRATION OF ELECTRONIC RECORDERS

IDMS: \# 20566

DATE:

WORK ORDER \#:

ID\#:

REVIEWED BY:

DATE:

GENERIC DATA SHEET FOR ELECTRONIC RECORDERS

\begin{tabular}{|c|c|c|c|c|c|c|c|c|c|c|}
\hline \multicolumn{11}{|c|}{ UUT Make/Model/Range: } \\
\hline $\begin{array}{l}\text { Input } \\
\text { Unit: }\end{array}$ & \multicolumn{2}{|c|}{$\begin{array}{l}\text { Expected } \\
\text { Response }\end{array}$} & \multicolumn{2}{|c|}{ Channel \#29 } & \multicolumn{2}{|c|}{ Channel \# 30} & \multicolumn{2}{|c|}{ Channel \#31 } & \multicolumn{2}{|c|}{ Channel \#32 } \\
\hline${ }^{\circ} \mathrm{F}$ & From & To & $\begin{array}{c}\text { As- } \\
\text { Found }\end{array}$ & $\begin{array}{l}\text { As- } \\
\text { Left }\end{array}$ & $\begin{array}{c}\text { As- } \\
\text { Found }\end{array}$ & $\begin{array}{l}\text { As- } \\
\text { Left }\end{array}$ & $\begin{array}{l}\text { As- } \\
\text { Found }\end{array}$ & $\begin{array}{l}\text { As- } \\
\text { Left }\end{array}$ & $\begin{array}{l}\text { As- } \\
\text { Found }\end{array}$ & $\begin{array}{l}\text { As- } \\
\text { Left }\end{array}$ \\
\hline 0 & & & -0.338 & & -0.317 & & $-0,340$ & & -0.348 & \\
\hline 400 & & & 399.702 & & 399,661 & & 399,651 & & 399.648 & \\
\hline 800 & & & 799,733 & & 799.717 & & 799.736 & & 744,722 & \\
\hline 1200 & & & 1200 & & 1200 & & 1200 & & 1200 & \\
\hline 1600 & & & 1600 & & 1600 & & 1600 & & 1600 & \\
\hline 2000 & & & 2000 & & 2000 & & 2000 & & 2000 & \\
\hline 2400 & & & 24,00 & & 2400 & & 2400 & & 2400 & \\
\hline & & & & & & & & & & \\
\hline & & & & & & & & & & \\
\hline & & & & & & & & & & \\
\hline & & & & & & & & & & \\
\hline & & & & & & & & & & \\
\hline & & & & & & & & & & \\
\hline & & & & & & & & & & \\
\hline & & & & & & & & & & \\
\hline & & & & & & & & & & \\
\hline & & & & & & & & & & \\
\hline
\end{tabular}

STANDARDS:

\begin{tabular}{|l|l|}
\hline ID Number: & Due Date: \\
\hline ID Number: & Due Date: \\
\hline ID Number: & Due Date: \\
\hline ID Number: & Due Date: \\
\hline
\end{tabular}

COMMENTS:

Continuation

$8-11$ 
ICS/CREA1022-DS Rev. 04 (03/08/2017)

Procedure: CALIBRATION OF ELECTRONIC RECORDERS

IDMS: \# 20566

TECHNICIAN(s)/BADGE(s):

DATE:

WORK ORDER \#:

ID\#:

REVIEWED BY:

DATE:

GENERIC DATA SHEET FOR ELECTRONIC RECORDERS

\begin{tabular}{|c|c|c|c|c|c|c|c|c|c|}
\hline \multicolumn{10}{|c|}{ UUT Make/Model/Range: } \\
\hline $\begin{array}{l}\text { Input } \\
\text { Unit: }\end{array}$ & $\begin{array}{l}\text { Expected } \\
\text { Response }\end{array}$ & \multicolumn{2}{|c|}{ Channel \#33 } & \multicolumn{2}{|c|}{ Channel \#34 } & \multicolumn{2}{|c|}{ Channel \#35 } & \multicolumn{2}{|c|}{ Channel \#36 } \\
\hline${ }^{\circ} \mathrm{F}$ & From $\quad$ To & $\begin{array}{l}\text { As- } \\
\text { Found }\end{array}$ & $\begin{array}{l}\text { As- } \\
\text { Left }\end{array}$ & $\begin{array}{c}\text { As- } \\
\text { Found }\end{array}$ & $\begin{array}{l}\text { As- } \\
\text { Left }\end{array}$ & $\begin{array}{c}\text { As- } \\
\text { Found }\end{array}$ & $\begin{array}{l}\text { As- } \\
\text { Left }\end{array}$ & $\begin{array}{l}\text { As- } \\
\text { Found }\end{array}$ & $\begin{array}{l}\text { As- } \\
\text { Left }\end{array}$ \\
\hline 0 & & 0.100 & & 0.045 & & 0.251 & & 0.199 & \\
\hline 400 & & 400.152 & & 400.123 & & 400,263 & & 400,231 & \\
\hline 800 & & 800.167 & & $800 \cdot 106$ & & 800.279 & & 800,247 & \\
\hline 1200 & & 1200 & & 1200 & & 1200 & & 1200 & \\
\hline 1600 & & 1600 & & 1600 & & 1600 & & 1600 & \\
\hline 2000 & & 2000 & & 2000 & & 2000 & & 2000 & \\
\hline 2400 & & 2400 & & 2400 & & 2400 & & $2+\infty 0$ & \\
\hline & & & & & & & & & \\
\hline & & & & & & & & & \\
\hline & & & & & & & & & \\
\hline & & & & & & & & & \\
\hline & & & & & & & & & \\
\hline & & & & & & & & & \\
\hline & & & & & & & & & \\
\hline & & & & & & & & & \\
\hline & & & & & & & & & \\
\hline & & & & & & & & & \\
\hline
\end{tabular}

STANDARDS:

\begin{tabular}{|l|l|}
\hline ID Number: & Due Date: \\
\hline ID Number: & Due Date: \\
\hline ID Number: & Due Date: \\
\hline ID Number: & Due Date: \\
\hline
\end{tabular}

COMMENTS:

continuation

$9-11$ 
ICS/CREA1022-DS Rev. 04 (03/08/2017)

Page 1 of 1

Procedure: CALIBRATION OF ELECTRONIC RECORDERS

TECHNICIAN(s)/BADGE(s):

DATE:

WORK ORDER \#:

ID\#:

REVIEWED BY:

DATE:

GENERIC DATA SHEET FOR ELECTRONIC RECORDERS

\begin{tabular}{|c|c|c|c|c|c|c|c|c|c|c|}
\hline \multicolumn{11}{|c|}{ UUT Make/Model/Range: } \\
\hline $\begin{array}{l}\text { Input } \\
\text { Unit: }\end{array}$ & \multicolumn{2}{|c|}{$\begin{array}{l}\text { Expected } \\
\text { Response }\end{array}$} & \multicolumn{2}{|c|}{ Channel \#37 } & \multicolumn{2}{|c|}{ Channel \#38 } & \multicolumn{2}{|c|}{ Channel \#39 } & \multicolumn{2}{|c|}{ Channel \#40 } \\
\hline${ }^{\circ} \mathrm{F}$ & From & To & $\begin{array}{l}\text { As- } \\
\text { Found }\end{array}$ & $\begin{array}{l}\text { As- } \\
\text { Left }\end{array}$ & $\begin{array}{l}\text { As- } \\
\text { Found }\end{array}$ & $\begin{array}{l}\text { As- } \\
\text { Left }\end{array}$ & $\begin{array}{l}\text { As- } \\
\text { Found }\end{array}$ & $\begin{array}{l}\text { As- } \\
\text { Left }\end{array}$ & $\begin{array}{l}\text { As- } \\
\text { Found }\end{array}$ & $\begin{array}{l}\text { As- } \\
\text { Left }\end{array}$ \\
\hline 0 & & & 0,167 & & 0,189 & & 0.174 & & 0.180 & \\
\hline 400 & & & 400,178 & & 400.203 & & 400.183 & & 400.221 & \\
\hline 800 & & & 800.185 & & 800.255 & & 800,164 & & 800.212 & \\
\hline 1200 & & & 1200 & & 1200 & & 1200 & & 1200 & \\
\hline 1600 & & & 1600 & & 1600 & & 1600 & & 1600 & \\
\hline 2000 & & & 2000 & & 2000 & & 2000 & & 2000 & \\
\hline 24100 & & & 2400 & & 2400 & & 2400 & & 2400 & \\
\hline & & & & & & & & & & \\
\hline & & & & & & & & & & \\
\hline & & & & & & & & & & \\
\hline & & & & & & & & & & \\
\hline & & & & & & & & & & \\
\hline & & & & & & & & & & \\
\hline & & & & & & & & & & \\
\hline & & & & & & & & & & \\
\hline & & & & & & & & & & \\
\hline & & & & & & & & & & \\
\hline
\end{tabular}

STANDARDS:

\begin{tabular}{|l|l|}
\hline ID Number: & Due Date: \\
\hline ID Number: & Due Date: \\
\hline ID Number: & Due Date: \\
\hline ID Number: & Due Date: \\
\hline
\end{tabular}

COMMENTS: Continuation $\quad$ Co-11 
DATA SHEET

ICS/CREA1022-DS Rev. 04 (03/08/2017)

Page 1 of 1

Procedure: CALIBRATION OF ELECTRONIC RECORDERS

IDMS: \# 20566

TECHNICIAN(s)/BADGE(s):

DATE:

WORK ORDER \#:

ID\#:

REVIEWED BY:

DATE:

GENERIC DATA SHEET FOR ELECTRONIC RECORDERS

\begin{tabular}{|c|c|c|c|c|c|c|c|c|c|c|}
\hline \multicolumn{11}{|c|}{ UUT Make/Model/Range: } \\
\hline \multirow{2}{*}{$\begin{array}{l}\text { Input } \\
\text { Unit: } \\
{ }^{\circ} F\end{array}$} & \multicolumn{2}{|c|}{$\begin{array}{l}\text { Expected } \\
\text { Response }\end{array}$} & \multicolumn{2}{|c|}{ Channel \#41 } & \multicolumn{2}{|c|}{ Channel \# 42} & \multicolumn{2}{|c|}{ Channel \#43 } & \multicolumn{2}{|c|}{ Channel \# } \\
\hline & From & To & $\begin{array}{l}\text { As- } \\
\text { Found }\end{array}$ & $\begin{array}{l}\text { As- } \\
\text { Left }\end{array}$ & $\begin{array}{c}\text { As- } \\
\text { Found }\end{array}$ & $\begin{array}{l}\text { As- } \\
\text { Left }\end{array}$ & $\begin{array}{c}\text { As- } \\
\text { Found }\end{array}$ & $\begin{array}{l}\text { As- } \\
\text { Left }\end{array}$ & $\begin{array}{l}\text { As- } \\
\text { Found }\end{array}$ & $\begin{array}{l}\text { As- } \\
\text { Left }\end{array}$ \\
\hline 0 & & & 0.170 & & -0.044 & & -0.148 & & & \\
\hline 400 & & & 400.194 & & 400.136 & & 399,903 & & & \\
\hline 800 & & & 800,184 & & 800,148 & & 799.927 & & & \\
\hline 1200 & & & 1200 & & 1200 & & 1200 & & & \\
\hline 1600 & & & 1600 & & 1600 & & 1600 & & & \\
\hline 2000 & & & 2000 & & 2000 & & 2000 & & & \\
\hline 2400 & & & 2400 & & 2400 & & & & & \\
\hline & & & & & & & & & & \\
\hline & & & & & & & & & & \\
\hline & & & & & & & & & & \\
\hline & & & & & & & & & & \\
\hline & & & & & & & & & & \\
\hline & & & & & & & & & & \\
\hline & & & & & & & & & & \\
\hline & & & & & & & & & & \\
\hline & & & & & & & & & & \\
\hline & & & & & & & & & & \\
\hline
\end{tabular}

STANDARDS:

\begin{tabular}{|l|l|}
\hline ID Number: & Due Date: \\
\hline ID Number: & Due Date: \\
\hline ID Number: & Due Date: \\
\hline ID Number: & Due Date: \\
\hline
\end{tabular}

COMMENTS:

continuation

$11-11$ 


\section{DETTA M}

Delta M Corporation 1003 Larsen Drive

Oak Ridge, TN 37830

$\mathrm{T}-(865) 483-1569$

$F-(865) 483-1142$

U. ISO $9001: 2008$

10000442QM08

\section{Material Certification Documentation}

The following documents are to certify that the material and test data as described below conforms in accordance with the requirements and specifications stated within the Purchase Order.

\begin{tabular}{|c|c|}
\hline Customer : & $\begin{array}{l}\text { UT-Battelle, LLC for the Dept. of Energy } \\
1 \text { Bethel Valley Road, c/o ORNL } \\
\text { Oak Ridge, TN } 37830\end{array}$ \\
\hline P.O. No. : & 4000150155 \\
\hline D.M. Job No. & TC-160365 \\
\hline Mat'l Desc. : & T5-U-062-304-K-M-600 Thermocouple \\
\hline Mat'l Trace : & $\begin{array}{l}.062-\mathrm{K}-304-\mathrm{MgO} \text { - PN: } 100472 \\
\text { PO\# } 160339\end{array}$ \\
\hline Quantity & $100 p c(95 p c-160339.1 / 5 p c-160339.2)$ \\
\hline
\end{tabular}

\section{Certificate Of Compliance}

This certifies that the articles and/or services supplied to UT-Battelle, LLC

by Delta M Corporation on October $12^{\text {th }}, 2016$ are in Compliance with the requirements of your

Purchase Order $\underline{4000150155}$. This Certification also applies to any documented amendments and/or clarifications pertaining to this stated Purchase Order.

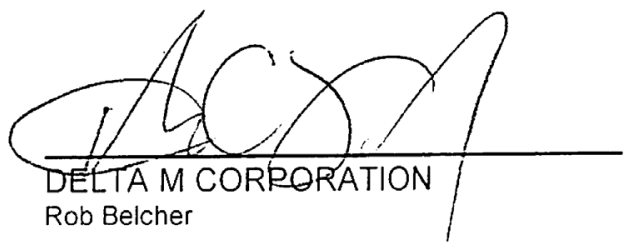

DMF171 Material Certification Documentation 1/16/08 


\section{MATERIAL CERTIFICATE}

Material Heat \#: 39700

ILC Sales Order \#: 216492

Customer P.O \#: 160339
Material Description: 062-KS-304

Customer: DELTA M

The materials and services supplied are in conformance with ASTM E585/585M-12 and/or customer purchase order requirements. Thermocouple material has been calibrated as covered by ASTM E-220 07a, ASTM E-230/E230M, AMS 2750, ANSI/NCSL Z540.1 and ITP 0017 and is traceable to the National Institute of Standards and Technology.

CALIBRATION REPORT

\begin{tabular}{|l|l|l|}
\hline Actual Temperature $\left({ }^{\circ} \mathrm{F}\right)$ & Measured Temperature $\left({ }^{\circ} \mathrm{F}\right)$ & Deviation $\left({ }^{\circ} \mathrm{F}\right)$ \\
\hline 1000.515 & 1004.0 & 3.486 \\
\hline 1001.952 & 1005.309 & 3.357 \\
\hline 1504.813 & 1508.371 & 3.559 \\
\hline 1504.484 & 1508.327 & 3.844 \\
\hline 1996.717 & 2002.973 & 6.256 \\
\hline 1996.412 & 2002.783 & 6.371 \\
\hline
\end{tabular}

RAW MATERIALS REPORT

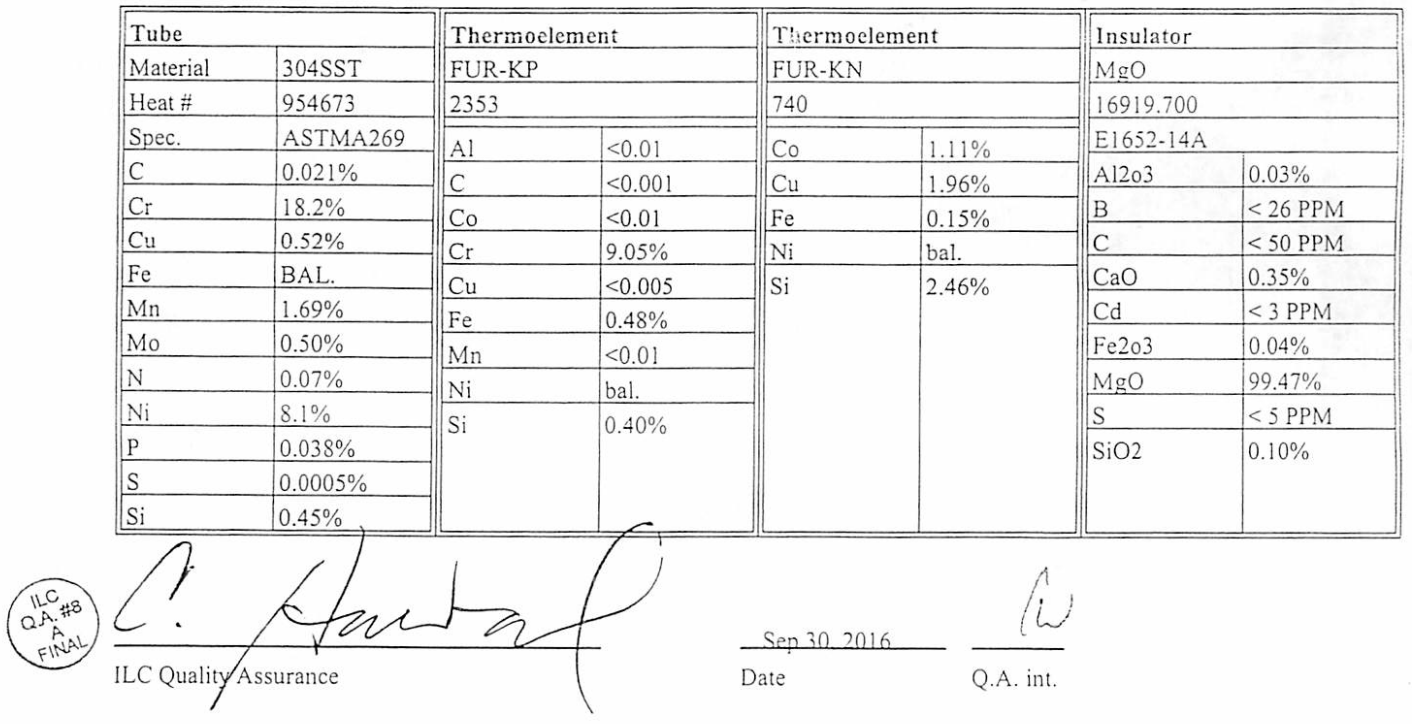




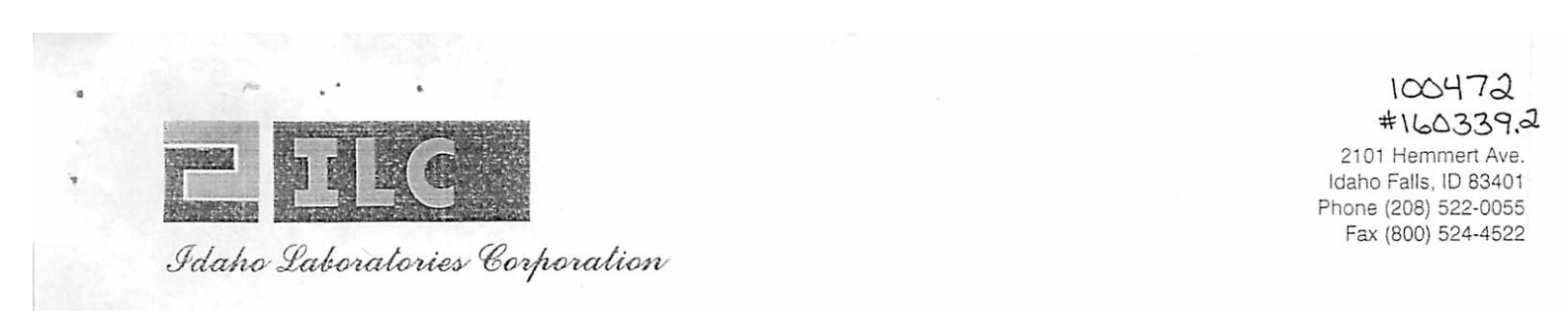

\title{
MATERIAL CERTIFICATE
}

Material Heat \#: 39288

ILC Sales Order \#: 216492

Material Description: 062-KS-304

Customer P.O. \#: 160339

\author{
Customer: DELTA M
}

The materials and services supplied are in conformance with ASTM E585/585M-12 and/or customer purchase order requirements. Thermocouple material has been calibrated as covered by ASTM E-220 07a, ASTM E-230/E230M, AMS 2750, ANSI/NCSL Z540.1 and ITP 0017 and is traceable to the National Institute of Standards and Technology.

CALIBRATION REPORT

\begin{tabular}{|l|l|l|}
\hline Actual Temperature $\left({ }^{\circ} \mathrm{F}\right)$ & Measured Temperature $\left({ }^{\circ} \mathrm{F}\right)$ & Deviation $\left({ }^{\circ} \mathrm{F}\right)$ \\
\hline 1000.0 & 1000.57 & 0.57 \\
\hline 1000.0 & 1000.77 & 0.77 \\
\hline 1500.0 & 1502.48 & 2.48 \\
\hline 1500.0 & 1503.08 & 3.08 \\
\hline 2000.0 & 2004.39 & 4.39 \\
\hline 2000.0 & 2005.4 & 5.4 \\
\hline
\end{tabular}

RAW MATERIALS REPORT

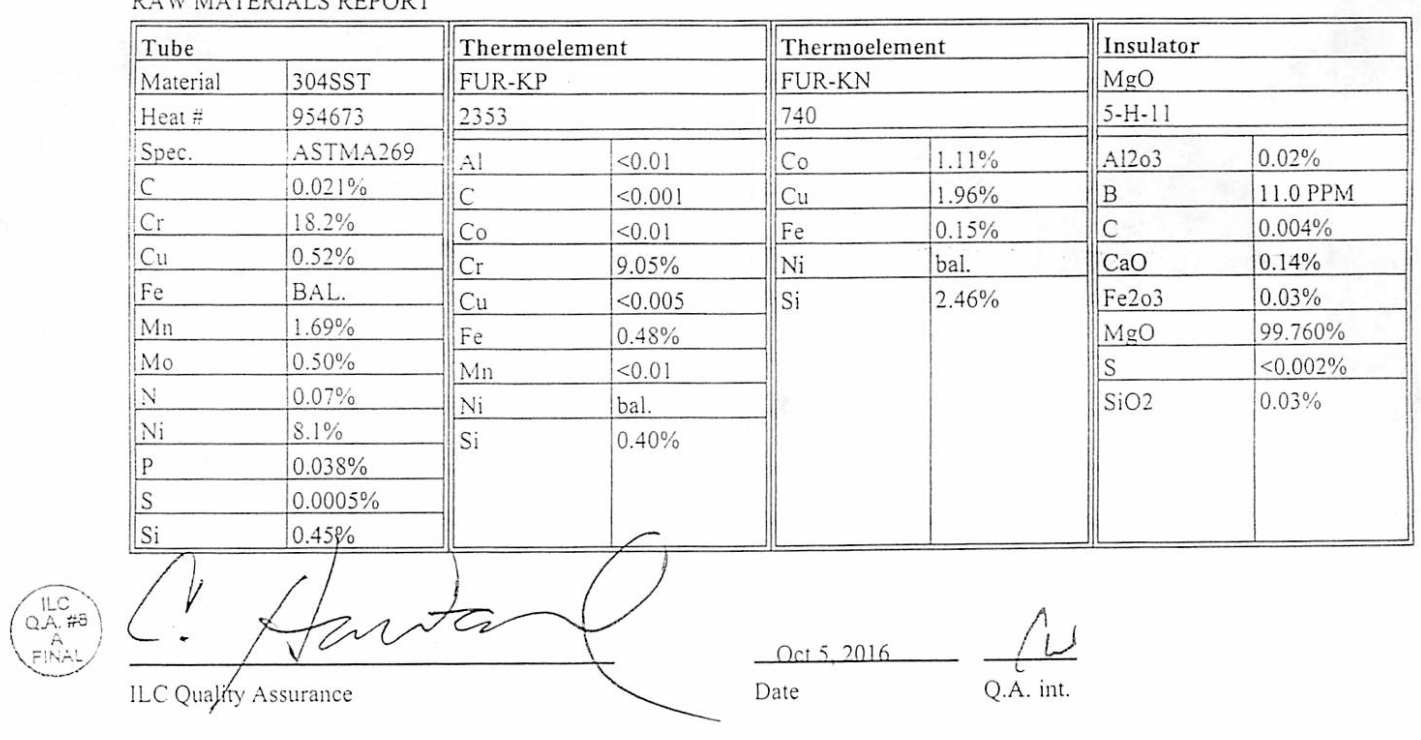




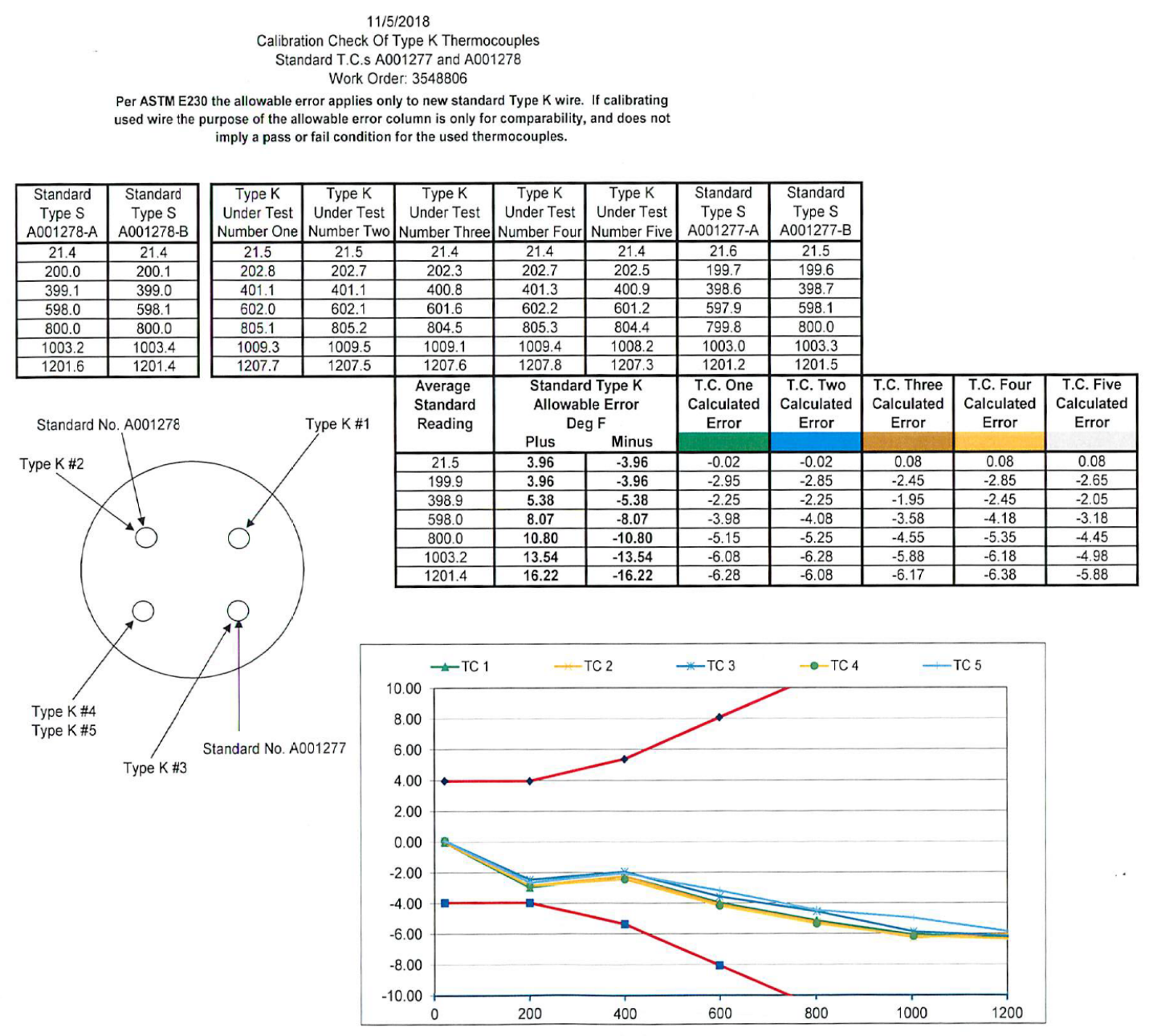




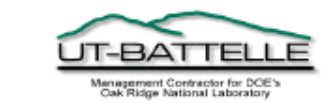

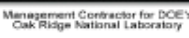

Calibration Results

Oak Ridge National Laboratory

ORNL Metrology Laboratory

Oak Ridge. TN $37831-6366$

\begin{tabular}{|c|c|c|}
\hline $\begin{array}{l}\text { Unit Under Test Information } \\
\text { Manufacturer: Stanley } \\
\text { Description: } 40 \text { Foot Tape Measure } \\
\text { Model Number: } 33-740 \\
\text { Serial Number: None } \\
\text { Asset / ID Number: A006327 } \\
\text { Custodian: Oscar A Martinez } \\
\text { Work Order Number: 2018000749 }\end{array}$ & $\begin{array}{l}\text { Customer Information } \\
\text { Oscar A Martinez } \\
\text { Building } 5700 \\
\text { Room H320 } \\
\text { Mail Stop } 6170\end{array}$ & $\begin{array}{l}\text { Test Information } \\
\text { Certificate Number: 2018000749 } \\
\text { Overall Result: Pass } \\
\text { Performed on: } 3 / 20 / 2018 \\
\text { Next Cal Due: } 3 / 20 / 2023 \\
\text { Performed by: Jerry Freeman } \\
\text { Environment: } 20^{\circ} \mathrm{C} \quad 46 \% \text { Rh } \\
\text { Received: In Tolerance }\end{array}$ \\
\hline Notoc: & & \\
\hline
\end{tabular}

ORNL Metrology Laboratory (ORNL ML) certifies that the above listed instrument meets or exceeds all specifications as stated in the referenced procedure unless otherwise noted. This Report of Calibration applies only to the item being calibrated, identified above.

This calibration report documents the traceability to national standards, which realize the units of measurement according to the International System of Units (SI). Calibration data and conformity assessment (Pass/Fail decision) is limited to the performance of the instrument at the time of test. The "Next Cal Due" date is based on manufacturer's recommendations or best calibration practices and with customer agreement (in the case of external ORNL customers); the instrument should not be used past this date without recalibration. This report shall not be reproduced, except in full, unless written penmission for an approved abstract is obtained from ORNL ML. Any report containing accredited data shall not be used to claim product certification, approval, or endorsement by NVL.AP, NIST, or any agency of the Federal Government. Calibration reports without authorizing signature(s) are not valid.

For accredited data, measurement uncertainties at the time of test, expressed in base units, are given on the following pages, where applicable. They are calculated in accordance with the methods described in EA-4/02, NIST TN1297, DKD-3, or other applicable documents that comply with the Guide to the Uncertainty in Measurement (GUM), using a coverage factor of $\mathrm{k}=2$, corresponding to a confidence level of approximately $95 \%$. Unless otherwise indicated, any conformity determination in this report is based on a Test Uncertainty Ratio (TUR) of $4: 1$ or greater. Any TUR less than $4: 1$ will be identified in the test data. It is the responsibility of the instrument custodian, with the assistance of his/her Quality Representative, to determine whether this level of confidence for the determination of conformance is adequate for the intended use of this instrument

This calibration was performed using measurement standards traceable to the appropriate standard(s), maintained by the National Institute of Standards and Technology (NIST), to accepted intrinsic standards of measurement, or is derived by ratio type self-calibration techniques. The calibration system used to derive accredited data complies with the requirements of NIST Handbook 150, ANSINCSL Z540.1-1999 (R2002), ISO/IEC 17025.

\section{Standards Used}

\begin{tabular}{llll}
\hline ID & Description & Dervice Date & Due Date \\
0084705 & Agilent 5519A Laser Head (5530A System) & $4 / 2012017$ & $4 / 2012018$
\end{tabular}




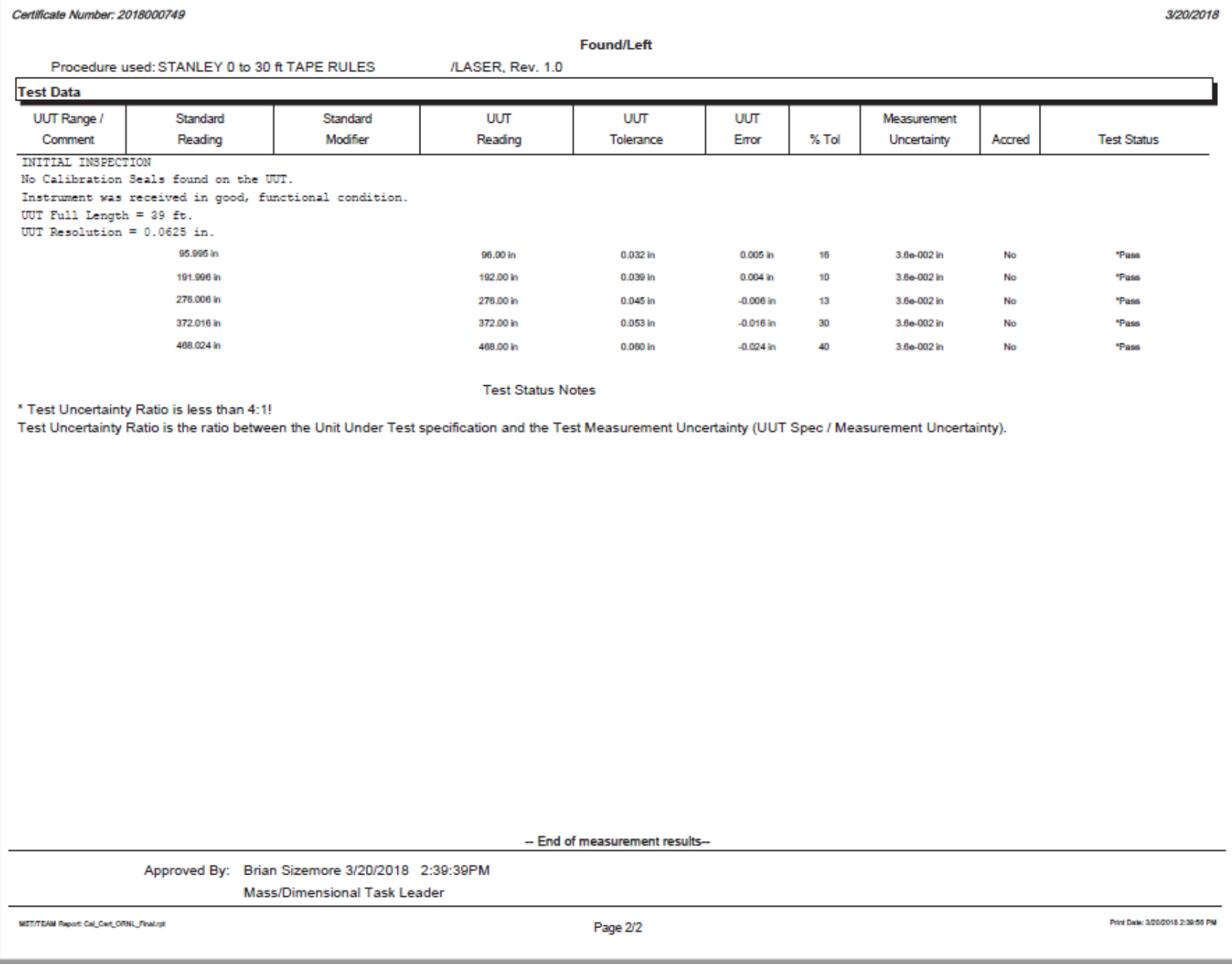




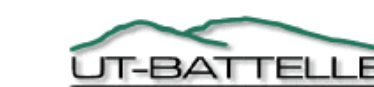

Manapement Contrector for DOE:s

\section{Calibration Results}

Oak Ridge National Laboratory

Mass Standard Laboratory

Bethel Valley Rd. Bldg. $2547 \mathrm{Rm}$. 4

Oak Ridge, IN 37831

Phone: 865574.8978

\begin{tabular}{|c|c|c|}
\hline \multicolumn{2}{|c|}{ Unit Under Test Information } & \multirow{2}{*}{$\begin{array}{c}\text { Customer Information } \\
\text { Oscar A Martinez }\end{array}$} \\
\hline Manufacturer: & Mettler Toledo & \\
\hline Description: & Balance $32 \mathrm{Kg}$ & Building 5700 \\
\hline Model Number: & XP32001 & Room H320 \\
\hline $\begin{array}{l}\text { Serial Number: } \\
\text { Asset / ID Number: }\end{array}$ & $\begin{array}{l}\text { Unknown } \\
\text { A000593 }\end{array}$ & Mail Stop 6170 \\
\hline Custodian: & Oscar A Martinez & \\
\hline Work Order Number: & 2019002157 & \\
\hline \multicolumn{3}{|l|}{ Notes: } \\
\hline & Asset No. & Work Order No. \\
\hline & & \\
\hline
\end{tabular}
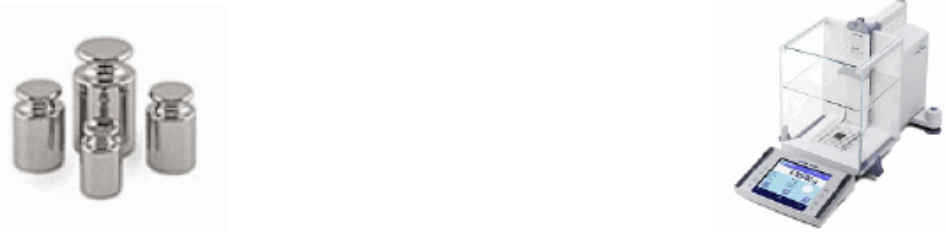

ORNL Metrology Laboratory (ORNL ML) certifies that the above listed instrument meets or exceeds all specifications as stated in the referenced procedure unless otherwise noted. This Report of Calibration applies only to the item being calibrated, identified above.

This calibration report documents the traceability to national standards, which realize the units of measurement according to the International System of Units (SI). Calibration data and conformity assessment (Pass/Fail decision) is limited to the performance of the instrument at the time of test. The "Next Cal Due" date is based on manufacturer's recommendations or best calibration practices; the instrument should not be used past this date without recalibration. This report shall not be reproduced, except in full, unless written permission for an approved abstract is obtained from ORNL ML. Any report containing accredited data shall not be used to claim product certification, approval, or endorsement by NVLAP, NIST, or any agency of the Federal Government. Calibration reports without authorizing signature(s) are not valid.

For accredited data, measurement uncertainties at the time of test, expressed in base units, are given on the following pages, where applicable. They are calculated in accordance with the methods described in EA-4/02, NIST TN1297, DKD-3, or other applicable documents that comply with the Guide to the Uncertainty in Measurement (GUM), using a coverage factor of $\mathrm{k}=2$, corresponding to a confidence level of approximately $95 \%$. The ability of the ORNL Metrology Laboratory to determine the conformance of the calibrated instrument to its specifications is limited to the level of certainty thereby indicated. It is the responsibility of the instrument custodian, with the assistance of his/her Quality Representative, to determine whether this level of confidence for the determination of conformance is adequate for the intended use of this instrument.

This calibration was performed using measurement standards traceable to the appropriate standard(s), maintained by the National Institute of Standards and Technology (NIST), to accepted intrinsic standards of measurement, or is derived by ratio type self-calibration techniques. The calibration system used to derive accredited data complies with the requirements of NIST Handbook 150, ANSI/NCSL Z540.1-1999 (R2002), ISO/IEC 17025.

Magnetic screening was not performed and any errors due to magnetic properties of the items were not considered in the uncertainty calculation.

Approved by: Brian Sizemore 7/26/2019

Mass/Dimensional Task Leader 
Oak Ridge National Laboratory

Mass Metrology

Building 2547 Room 4

Oak Ridge, TN 37831

CALIBRATION REPORT

Delta Range Balance

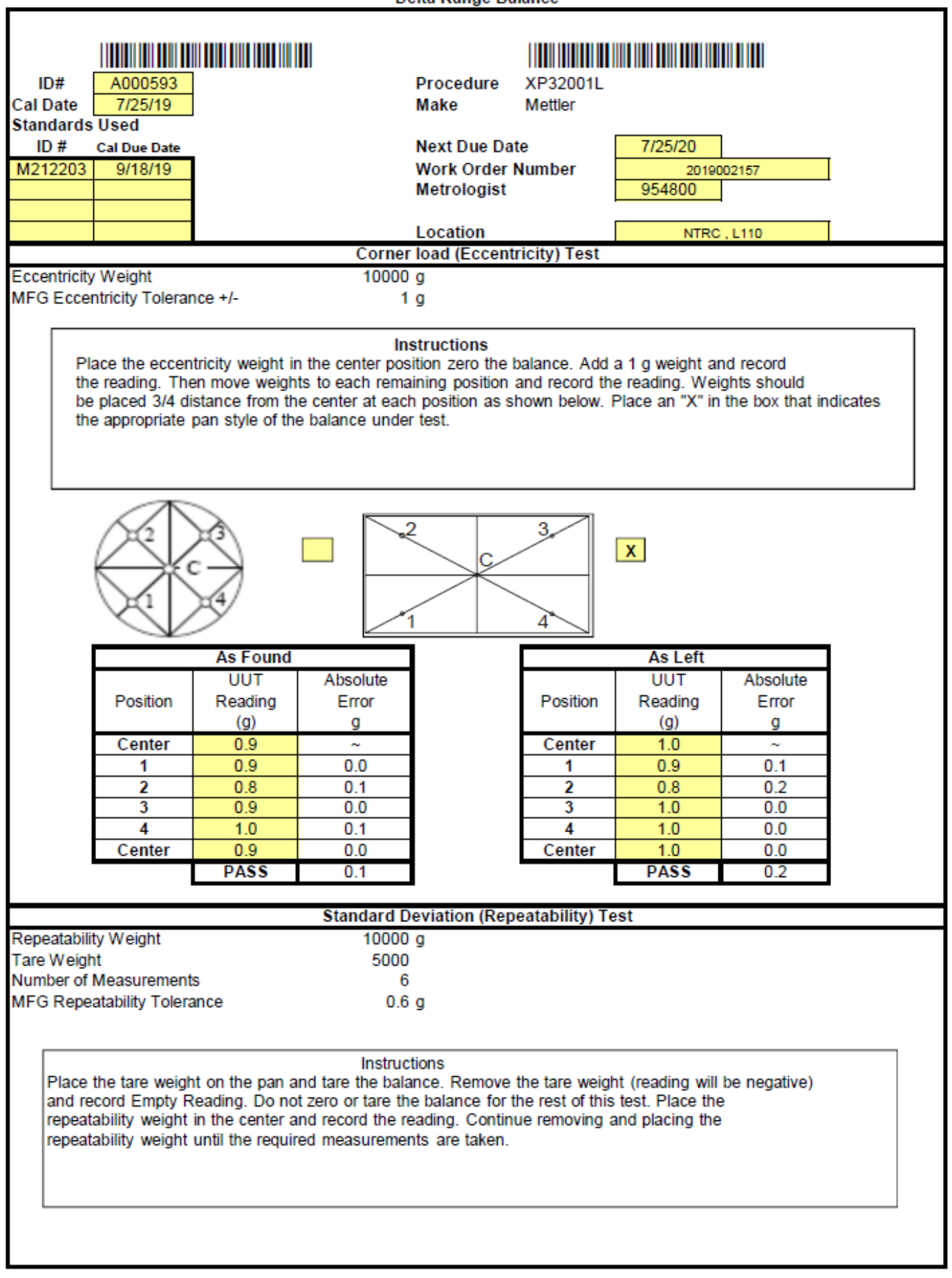




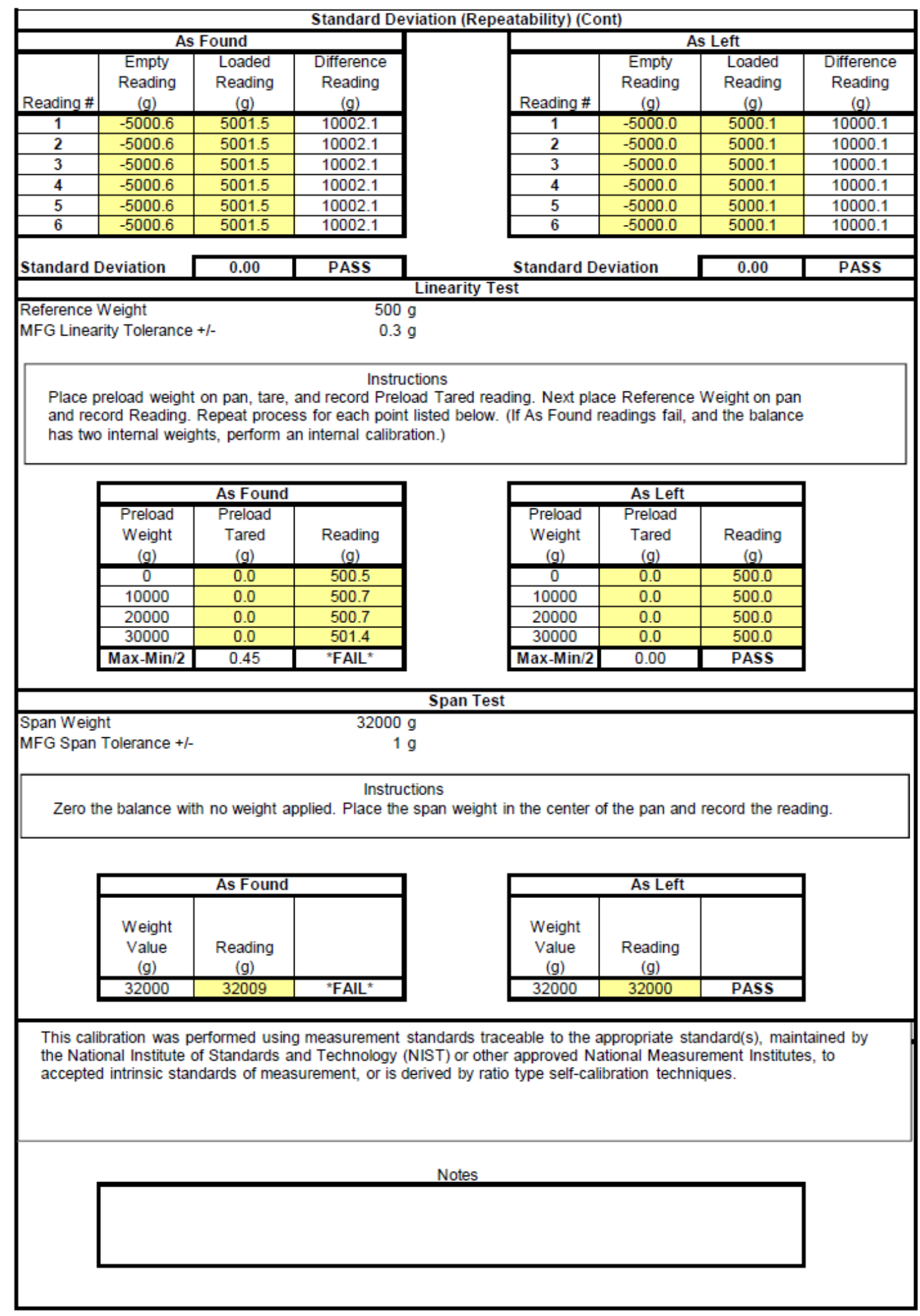




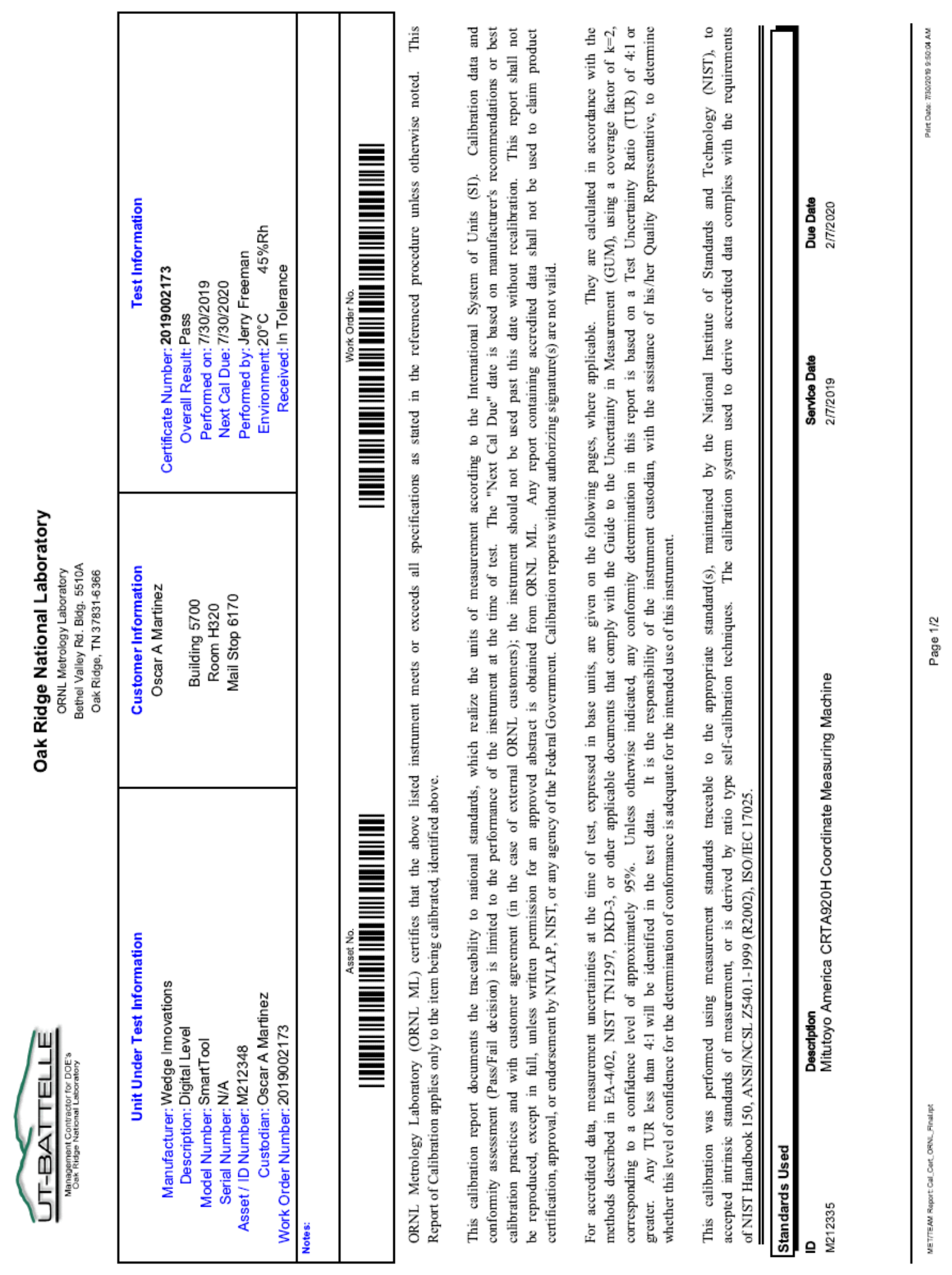




$$
1
$$




\title{
OAK RIDGE NATIONAL LABORATORY
}

\section{QUALITY DEPARTMENT}

TEST REPORT

\section{PRECISION LEVEL}

ITEM: LEVEL PRECISION 6"

Serial Number:

MANUFACTURER: SMARTTOOL

REF Number: $311-006-501$

CUSTODIAN: O.A. Martinez

\begin{abstract}
This is to certify that this level has a sensitivity of $0.1 /$ per degree and a calibrated accuracy of $0.1 / \mathrm{per}$ degree division.
\end{abstract}

This tool calibrated by reversal technique on granite surface plate.

Temperature: $68^{\circ} \mathrm{F}$

Date $7 / 30 / 2019$

Calibrated By 701194

Due Date $7 / 30 / 2020$

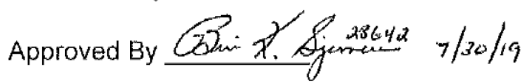

NATIONAL INSTITUTE OF STANDARDS AND TECHNOLOGY TRACEABILITY

ESTABLISHED THROUGH ORNL PRIMARY STANDARDS

Item Number Calibration Date Due Date

$\begin{array}{lll}\text { M212335 } 2 / 7 / 19 & 2 / 7 / 20\end{array}$ 


\section{Oak Ridge National Laboratory \\ Metrology Laboratory \\ Instrument Out of Tolerance Notification}

The following instrument(s) was(were) found Out of Tolerance (OOT) in the As Found Calibration process. In accordance with SBMS Calibration Subject Area procedure "Verifying the Quality of Calibration", this notification requires the recipient to take the following actions:

1. compare the OOT condition against the requirements for each application of the instrument,

2. determine if there were any impacts,

3. document the OOT evaluation, and

4. implement appropriate actions.

\begin{tabular}{|c|c|c|}
\hline$\underline{\text { Instrument ID Number: }}$ & A000593 & Model Name/Number: XP32001 \\
\hline Instrument Description: & Balance $32 \mathrm{Kg}$ & Work Order Number: 2019002157 \\
\hline Manufacturer: & Mettler Toledo & \\
\hline
\end{tabular}

Notes:

See the Calibration Data attached to the instrument for a full description of the As Found As Left condition. 


\begin{tabular}{|c|c|c|}
\hline 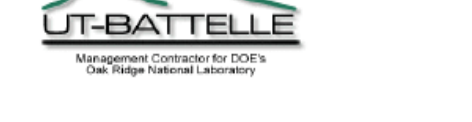 & $\begin{array}{l}\text { idge National Labor } \\
\text { ORNL Metrology Laboratory } \\
\text { Bethel Valley Rd. Bldg. } 5510 \mathrm{~A} \\
\text { Oak Ridge, TN 37831-6386 }\end{array}$ & \\
\hline $\begin{array}{l}\text { Unit Under Test Information } \\
\text { Manufacturer. Oak Ridge National Laboratory } \\
\text { Description: 1 Meter Length Standard } \\
\text { Model Number: None } \\
\text { Serial Number: N/A } \\
\text { Asset / ID Number: A001146 } \\
\text { Custodian: Matthew R Feldman } \\
\text { Work Order Number: } 2016002294\end{array}$ & $\begin{array}{l}\text { Customer Information } \\
\text { Matthew R Feldman } \\
\text { Bldg } 5700 \\
\text { Room N323 } \\
\text { Mail Stop } 6170 \\
865-241-8801\end{array}$ & $\begin{array}{l}\text { Test Information } \\
\text { Certificate Number: 2016002294 } \\
\text { Overall Result: Pass } \\
\text { Performed on: 6/30/2016 } \\
\text { Next Cal Due: 6/30/2021 } \\
\text { Performed by: Jerry Freeman } \\
\text { Environment: 20 } \quad 47 \% \text { Rh } \\
\text { Received: In Tolerance }\end{array}$ \\
\hline \multicolumn{3}{|l|}{\begin{tabular}{|l|} 
Notes: \\
\end{tabular}} \\
\hline $\begin{array}{c}\text { Asset No. } \\
\|\|\|\|\|\|||||||||\end{array}$ & \multicolumn{2}{|c|}{$\begin{array}{c} \\
\end{array}$} \\
\hline
\end{tabular}

ORNL Metrology Laboratory (ORNL ML) certifies that the above listed instrument meets or exceeds all specifications as stated in the referenced procedure unless otherwise noted. This Report of Calibration applies only to the item being calibrated, identified above.

This calibration report documents the traceability to national standards, which realize the units of measurement according to the International System of Units (SI). Calibration data and conformity assessment (Pass/Fail decision) is limited to the performance of the instrument at the time of test. The "Next Cal Due" date is based on manufacturer's recommendations or best calibration practices and with customer agreement (in the case of extemal ORNL customers); the instrument should not be used past this date without recalibration. This report shall not be reproduced, except in full, unless written permission for an approved abstract is obtained from ORNL ML. Any report containing accredited data shall not be used to claim product certification, approval, or endorsement by NVLAP, NIST, or any agency of the Federal Govemment. Calibration reports without authorizing signature(s) are not valid.

For accredited data, measurement uncertainties at the time of test, expressed in base units, are given on the following pages, where applicable. They are calculated in accordance with the methods described in EA-4/02, NIST TN1297, DKD-3, or other applicable documents that comply with the Guide to the Uncertainty in Measurement (GUM), using a coverage factor of k=2, corresponding to a confidence level of approximately $95 \%$. Unless otherwise indicated, any conformity determination in this report is based on a Test Uncertainty Ratio (TUR) of $4: 1$ or greater. Any TUR less than $4: 1$ will be identified in the test data. It is the responsibility of the instrument custodian, with the assistance of his/her Quality Representative, to determine whether this level of confidence for the determination of conformance is adequate for the intended use of this instrument.

This calibration was performed using measurement standards traceable to the appropriate standard(s), maintained by the National Institute of Standards and Technology (NIST), to accepted intrinsic standards of measurement, or is derived by ratio type self-calibration techniques. The calibration system used to derive accredited data complies with the requirements of NIST Handbook 150, ANSINCSL Z540.1-1999 (R2002), ISO/IEC 17025

\begin{tabular}{lll}
\hline \hline Standards Used & & Service Date \\
ID & Description & Due Date \\
M212335 & Mitutoyo America CRTA920H Coordinate Measuring Machine & $2 / 11 / 2016$
\end{tabular}


- End of measurement results-

Approved By: Brian Sizemore 7/7/2016

Mass/Dimensional Task Leader

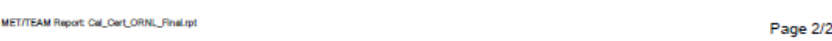




\section{OAK RIDGE NATIONAL LABORATORY \\ METROLOGY DEPARTMENT \\ TEST REPORT}

ITEM: 39.38" LENGTH STANDARD

Serial Number: A001146

CUSTODIAN: M. FELDMAN

\begin{tabular}{|l|l|c|l|}
\hline & AS FOUND & REQUIREMENT & INSPECTION METHOD \\
\hline LENGTH & $39.4000 / 39.4010$ & 39.38 & CMM \\
\hline
\end{tabular}

Temperature: $68^{\circ} \mathrm{F}$

Date $6 / 30 / 16$

Inspector $\quad$ '701194

Date Due 6/30/2021

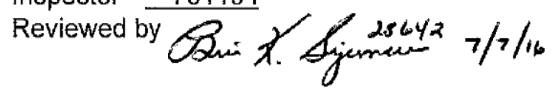

NATIONAL INSTITUTE OF STANDARDS AND TECHNOLOGY TRACEABILITY

ESTABLISHED THROUGH ORNL PRIMARY STANDARDS

Standards used:

ID\#

Calibration Due Date

M212335

$2 / 11 / 17$ 
